\title{
Geochronology of the Palaeoproterozoic Kautokeino Greenstone Belt, Finnmark, Norway: Tectonic implications in a Fennoscandia context
}

\author{
Bernard Bingen ${ }^{1,2}$, Arne Solli', Giulio Viola ${ }^{1,3}$, Espen Torgersen', Jan Sverre Sandstad', \\ Martin J. Whitehouse ${ }^{4}$, Torkil S. Røhr' ${ }^{1}$, Morgan Ganerød' \& Aziz Nasuti'
}

${ }^{1}$ Geological Survey of Norway, PO Box 6315 Sluppen, 7491 Trondheim, Norway.

${ }^{2}$ Departement of Geology, University of Liège, 4000, Liège, Belgium.

${ }^{3}$ Department of Geology and Mineral Resources Engineering, Norwegian University of Science and Technology, 7491, Trondheim, Norway.

${ }^{4}$ Swedish Museum of Natural History, 104 05, Stockholm, Sweden.

E-mail corresponding author (Bernard Bingen): bernard.bingen@ngu.no

Zircon $\mathrm{U}-\mathrm{Pb}$ geochronological data in 18 samples from Finnmarksvidda and one sample from the Repparfjord Tectonic Window, northern Norway, constrain the evolution of the Palaeoproterozoic Kautokeino Greenstone Belt and neighbouring units in a Fennoscandia context. The Jergul Complex is an Archaean cratonic block of Karelian affinity, made of variably gneissic, tonalite-trondhjemite-granodiorite-granite plutonic rocks formed between $2975 \pm 10$ and $2776 \pm 6 \mathrm{Ma}$. It is associated with the Archaean Goldenvárri greenstone-schist formation. At the base of the Kautokeino Greenstone Belt, the Masi Formation is a typical Jatulian quartzite, hosting a Haaskalehto-type, albite-magnetite-rich, mafic sill dated at $2220 \pm 7 \mathrm{Ma}$. The Likčá and Čáskejas formations represent the main event of basaltic magmatism. A synvolcanic metagabbro dates this magmatism at $2137 \pm 5 \mathrm{Ma}$. The geochemical and $\mathrm{Nd}$ isotopic signature of the Čáskejas Formation $\left(\varepsilon_{\mathrm{Nd}}=+2.2 \pm 1.7\right)$ is remarkably similar to coeval dykes intruding the Archaean Karelian Craton in Finland and Russia $\left(\varepsilon_{\mathrm{Nd}}=+2.5 \pm 1.0\right)$. The Čáskejas Formation can be correlated with the Kvenvik Formation in the Alta-Kvænangen Tectonic Window. Two large granite plutons yield ages of $1888 \pm 7$ and $1865 \pm 8 \mathrm{Ma}$, and provide a maximum age for shearing along two prominent NNW-SSE-oriented shear zones recording Svecokarelian transpression. The Bidjovagge Au-Cu deposit formed around 1886 to $1837 \mathrm{Ma}$ and is also related to this NNW-SSE-oriented shear system. The Ráiseatnu Complex is mainly composed of granitic gneisses formed between $1868 \pm 13$ and $1828 \pm 5 \mathrm{Ma}$, and containing metasediment rafts and zircon xenocrysts ranging from c. 3100 to $2437 \mathrm{Ma}$. The Kautokeino Greenstone Belt and Ráiseatnu Complex are interpreted as Palaeoproterozoic, pericontinental, lithospheric domains formed during rifting between Archaean cratonic domains. They accommodated oblique convergence between the Karelian and the Norrbotten Archaean cratons during the Svecokarelian orogeny.

Keywords: Fennoscandia, greenstone, Archaean, Palaeoproterozoic, zircon, U-Pb geochronology

Electronic Supplement 1: Analytical methods.

Electronic Supplement 2: Whole-rock geochemical analyses.

Electronic Supplement 3: SIMS zircon U-Pb geochronological data, corrected for common $\mathrm{Pb}$.

Electronic Supplement 4: LA-ICP-MS zircon U-Pb geochronological data.

Electronic Supplement 5: Biotite ${ }^{40} \mathrm{Ar}-{ }^{39} \mathrm{Ar}$ data on sample ETO149 from Rødfjellet suite.

Received 27. January 2016 / Accepted 28. July 2016 / Published online 29. August 2016

\section{Introduction}

The Fennoscandian Shield hosts a rich geological record of the Archaean to Palaeoproterozoic evolution of the Earth (Daly et al., 2006; Slabunov et al., 2006; Hölttä et al., 2008). In the northeastern part of the shield (Fig. 1), Archaean complexes are separated by Palaeoproterozoic greenstone belts. The latter expose layered sedimentary-volcanic successions made mainly of mafic volcanic rocks, clastic and (bio)chemical sedimentary rocks and plutonic complexes formed between c. 2505 and $1880 \mathrm{Ma}$ (Pharaoh et al., 1987; Pharaoh \& Brewer, 1990; Hanski \& Huhma, 2005; Melezhik \& Hanski, 2013). Traditionally, the sedimentary-volcanic successions are interpeted

Bingen, B., Solli, A., Viola, G., Torgersen, E., Sandstad, J.S., Whitehouse, M.J., Røhr, T.S., Ganerød, M. \& Nasuti, A. 2016: Geochronology of the Palaeoproterozoic Kautokeino Greenstone Belt, Finnmark, Norway: Tectonic implications in a Fennoscandia context. Norwegian Journal of Geology 95, 365-396. http://dx.doi.org/10.17850/njg95-3-09. 


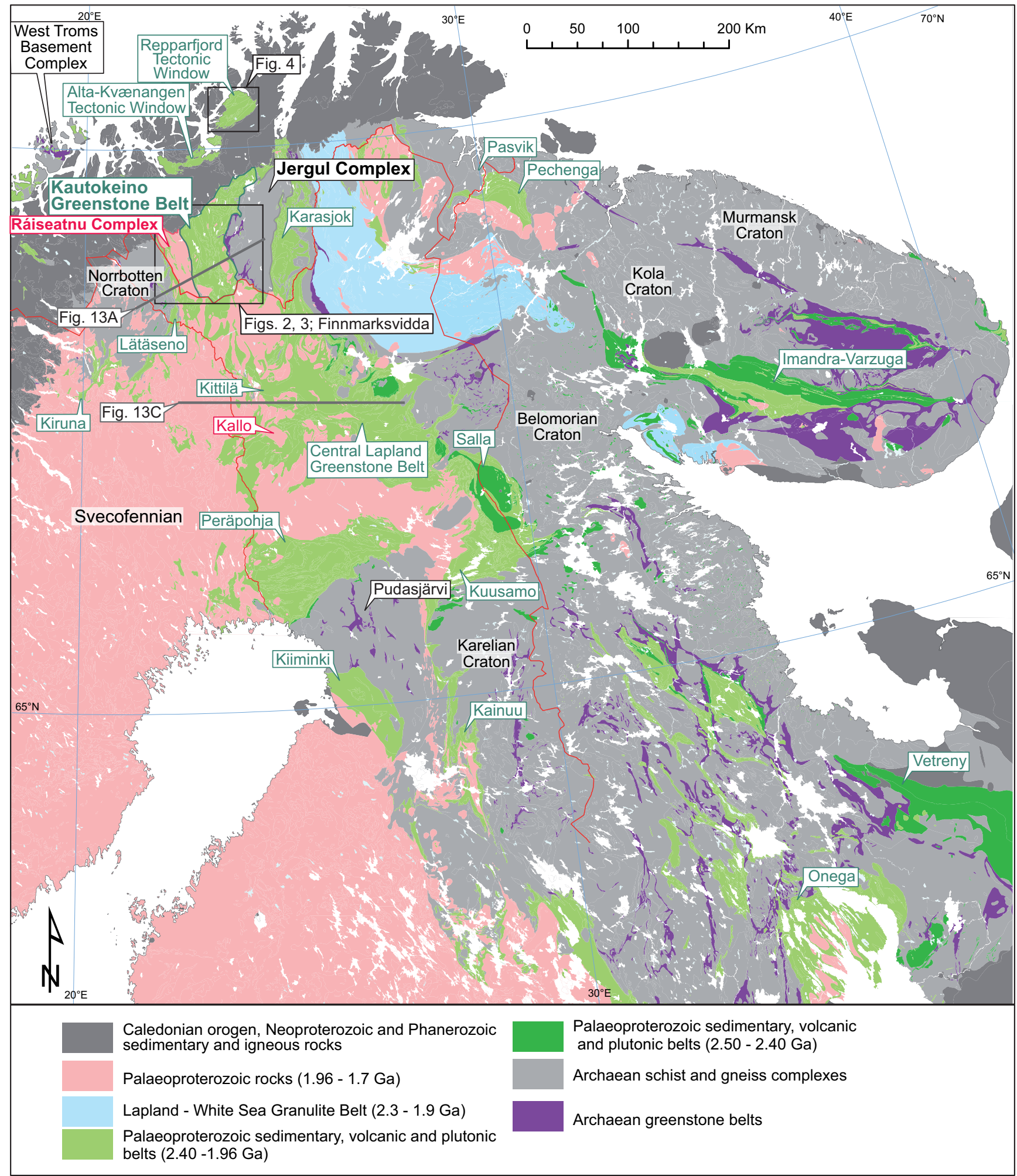

Figure 1. Sketch map of northern Fennoscandia, based on Koistinen et al. (2001), highlighting Archaean cratons, Archaean greenstones and Palaeoproterozoic greenstones. Cratons (black text): Belomorian Belt, Jergul Complex, Karelian Craton (with Pudasjävri), Kola Craton, Murmansk Craton, Norbbotten Craton, West Troms Basement Complex. Palaeoproterozoic greenstone-schist belts (green text): AltaKvenangen Tectonic Window, Central Lapland Greenstone Belt, including Kittilä and Salla belts, Imandra-Varzuga Belt, Kainuu Schist Belt, Karasjok Greenstone Belt, Kautokeino Greenstone Belt, Kiiminki Belt, Kuusamo Belt, Onega Basin, Pasvik and Pechenga Belts, Peräpohja Schist Belt, Repparfjord Tectonic Window and Vetreny Belt. 
as evidence for rifting and possibly dispersal of the Archaean continent(s) (e.g., Bogdanova et al., 2008; Lahtinen et al., 2008; Melezhik \& Hanski, 2013). They are interesting for a number of reasons. The mafic magmatic rocks provide a unique window into the evolution of the mantle during the Palaeoproterozoic (e.g., Puchtel et al., 1996). Sedimentary rocks record some of the conditions prevailing in the hydrosphere and atmosphere during the very specific period of the Earth's history when the atmosphere became oxidising (e.g., Melezhik et al., 2015b). The successions also host economically important mineral deposits, including $\mathrm{Cu}, \mathrm{Ni}$ and $\mathrm{Au}$ (Eilu, 2012; Martinsson et al., 2016).

This study is part of an initiative to characterise the geology of the large, but sparsely exposed, Kautokeino Greenstone Belt and surrounding units in Finnmarksvidda (inland part of west Finnmark) in northern Norway, as well as basement windows exposed in the Scandinavian Caledonides - the Alta-Kvænangen and Repparfjord Tectonic Windows - (Figs. 1-5; Henderson et al., 2015; Melezhik et al., 2015a; Nasuti et al., 2015a; Torgersen et al., 2015a, b). Available geochronological constraints on the geological evolution of Finnmarksvidda stem from four pioneering studies reporting $\mathrm{U}-\mathrm{Pb}, \mathrm{Pb}-\mathrm{Pb}, \mathrm{Rb}-\mathrm{Sr}$ and $\mathrm{Sm}-\mathrm{Nd}$ whole-rock and mineral isotopic analyses (Krill et al., 1985; Olsen \& Nilsen, 1985; Bjørlykke et al., 1990; Cumming et al., 1993). These studies produced several key dates to establish regional lithostratigraphic, geological and metallogenic models (Solli, 1983; Olesen \& Solli, 1985; Siedlecka et al., 1985; Bjørlykke et al., 1990; Cumming et al., 1993; Olesen \& Sandstad, 1993; Koistinen et al., 2001; Sandstad et al., 2012). In this paper, we report new $\mathrm{U}-\mathrm{Pb}$ geochronological data on 18 samples of the Kautokeino Greenstone Belt and surrounding units (Figs. 3, 5). We also take the opportunity to report $\mathrm{U}-\mathrm{Pb}$ and ${ }^{40} \mathrm{Ar}-{ }^{39} \mathrm{Ar}$ data in one of the rare samples of mafic rock from the Repparfjord Tectonic Window to contain zircon (Figs. 4, 5). The objectives of this study are to improve and recalibrate the regional lithostratigraphic model (Fig. 5), improve regional geological and tectonic evolution models, discuss the temporal constraints on the formation of the large Bidjovagge $\mathrm{Au}-\mathrm{Cu}$ deposit and integrate the new data in the broader context of the Palaeoproterozoic geotectonic evolution of Fennoscandia.

\section{Geological context}

\section{Palaeoproterozoic greenstone belts of Fennoscandia}

The northeastern part of the Fennoscandian Shield (Fig. 1) comprises six Archaean lithospheric blocks exposing mainly tonalite-trondhjemite-granite (TTG) associations. These are the Murmansk, Kola, Belomorian, Karelian and Norrbotten cratons (Daly et al., 2006;
Slabunov et al., 2006; Hölttä et al., 2008) and the West Troms Basement Complex forming a window in the Caledonides in northern Norway (Bergh et al., 2007, 2010; Myhre et al., 2013). The Archaean complexes are unconformably overlain and separated by a number of Palaeoproterozoic sedimentary-volcanic successions, metamorphosed in low- to medium-grade conditions. These are referred to as Karelian successions, and are traditionally divided into five stratigraphic systems, from bottom to top, the Sumian, Sariolian, Jatulian, Ludicovian and Kalevian systems (Hanski, 2001).

The geochronology of the Palaeoproterozoic sedimentary-volcanic successions, as well as of associated mafic plutonic rocks and related dyke swarms, has been hampered in decades by a paucity of zircon-bearing magmatic rocks to apply $\mathrm{U}-\mathrm{Pb}$ geochronology. Today, a growing body of $\mathrm{U}-\mathrm{Pb}$ and $\mathrm{Sm}-$ $\mathrm{Nd}$ geochronological data constrains formation of these successions in the interval between c. 2505 and $1930 \mathrm{Ma}$, with a general, but not systematic, decrease in age from the northeast to the southwest (Hanski \& Melezhik, 2013). It also shows that the sedimentary-volcanic successions have distinct lithostratigraphy and distinct geological evolutions (Hanski, 2001; Hanski \& Huhma, 2005; Hanski \& Melezhik, 2013; Melezhik \& Hanski, 2013). The geochronology, discontinuous nature and isotopic signature of mafic magmatism in Fennoscandia is elegantly illustrated in a $\varepsilon_{\mathrm{Nd}}$ vs. time diagram in Fig. 6 (references to data listed in the caption). The figure shows discontinuous magmatism between c. 2505 and 2090 Ma with main pulses peaking at c. 2440,2330, 2220 and $2140 \mathrm{Ma}$, followed by a less discontinuous magmatism in the interval between c. 2090 and $1930 \mathrm{Ma}$ (Fig. 6). The initial $\varepsilon_{\mathrm{Nd}}$ value of mafic magmatism increases with time in the interval between c. 2505 and $2090 \mathrm{Ma}$ (Fig. 6), from $\varepsilon_{\mathrm{Nd}}=-2$ at $2505 \mathrm{Ma}$ (Shalskiy dykes, Onega Basin, Russia; Mertanen et al., 2006) to $\varepsilon_{\mathrm{Nd}}=+4.4$ at 2090 Ma (Jouttiaapa basalts, Peräpohja Schist Belt, Finland; Huhma et al., 1990), followed by a stabilisation (or weak decrease) at around $\varepsilon_{\mathrm{Nd}}=+4$ in the interval between $c$. 2090 and $1930 \mathrm{Ma}$ (Kiruna greenstone, Norrbotten Craton, Sweden; Skiöld, 1986). The trend shows that the mantle producing basaltic magmas was slightly enriched in incompatible elements at the Archaean-Proterozoic boundary and that it became progressively more depleted with time to reach the model depleted mantle line at $2090 \mathrm{Ma}\left(\varepsilon_{\mathrm{Nd}}=+4.6\right)$. The trend also shows that the $\mathrm{Nd}$ isotopic signature of each pulse of mafic magmatism is uniform at the scale of the whole continent (Amelin \& Semenov, 1996; Puchtel et al., 1997; Stepanova et al., 2014). The systematic increase in $\varepsilon_{\mathrm{Nd}}$ value between $c$. 2505 and $2090 \mathrm{Ma}$ (Fig. 6) can be explained in two ways: (1) by a progressive change of asthenospheric sourcing, from a deep reservoir (plume reservoir) at c. $2505 \mathrm{Ma}$ to a more shallow depleted reservoir at c. $2090 \mathrm{Ma}$; or (2) by an accelerated depletion of a single asthenospheric source reservoir (evolving along a vector with average ${ }^{147} \mathrm{Sm} /{ }^{144} \mathrm{Nd}$ ratio of 0.3 ; Fig. 6). 


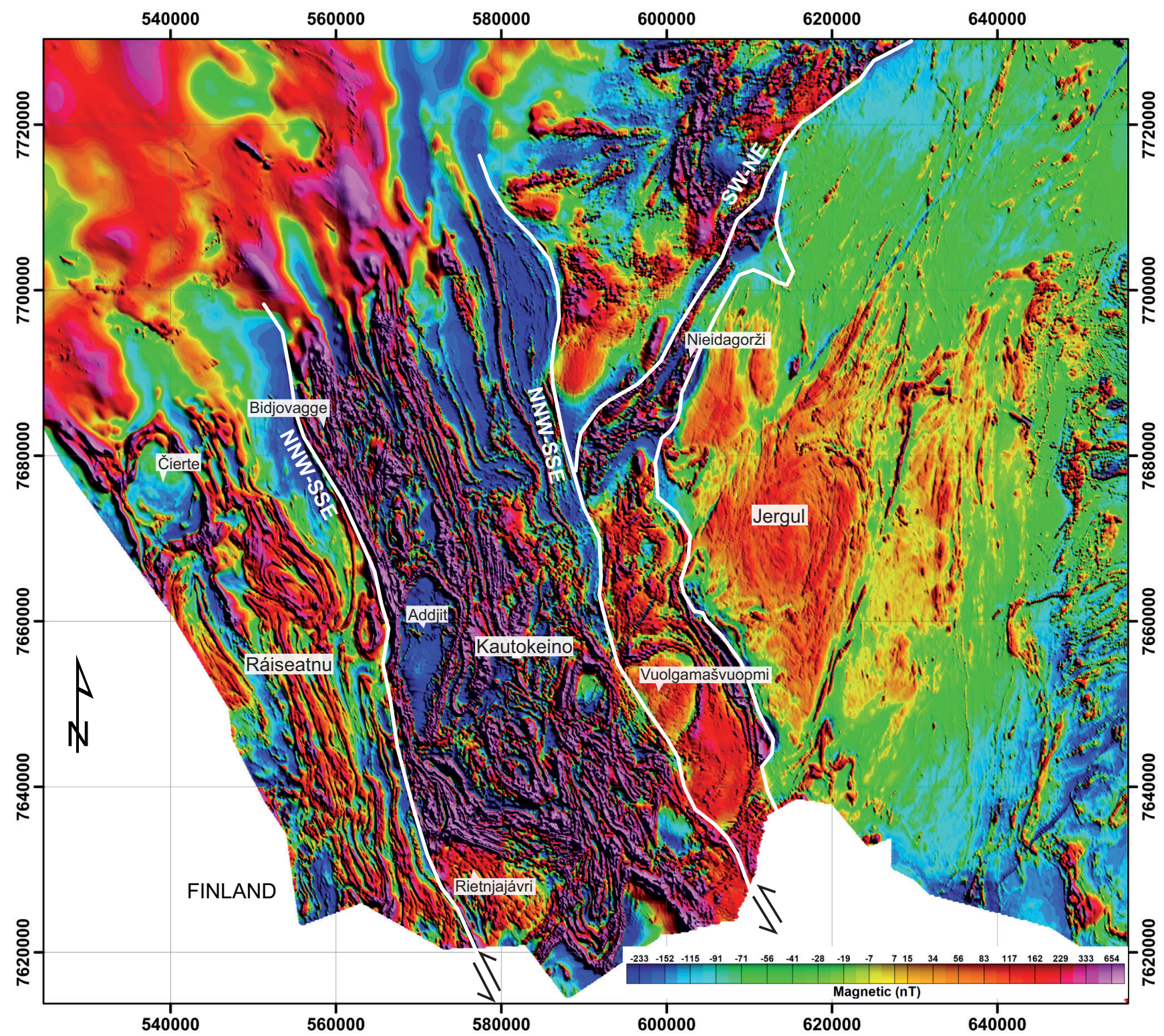

Figure 2. Aeromagnetic map of Finnmarksvidda with the Jergul Complex, Kautokeino Greenstone Belt and Ráiseatnu Complex, following Nasuti et al. $(2015 a, b)$ and Henderson et al. (2015) (UTM grid zone 34 in $\mathrm{m}$ ). The technical specifications are reported in these three publications. The map shows the NE-SW-trending and NNW-SSE-trending structural compartments defined by Henderson et al. (2015).

\section{Kautokeino Greenstone Belt and associated units}

The Kautokeino Greenstone Belt is one of the westernmost greenstone belts of Fennoscandia, located between the Karelian and Norrbotten cratons (Fig. 1). It is c. 40 $\mathrm{km}$ wide and $120 \mathrm{~km}$ long, and composed of a generally steeply-dipping, composite, sedimentary-volcanic succession dominated by foliated mafic metavolcanic rocks and clastic metasedimentary rocks. It is flanked by two felsic plutonic and metamorphic complexes, the Jergul (Jer'gul, Jergol) Gneiss Complex in the east and the Ráiseatnu (Raiscedno) Gneiss Complex in the west (Figs. 1-3; Olesen \& Solli, 1985; Siedlecka et al., 1985; Olesen \& Sandstad, 1993; all local names in this publication are spelled following the 2015 version of the online topographic map of the Norwegian Mapping Authority available at www.norgeskart.no; older or alternative spellings are given in parentheses the first time the name is used). Geological mapping performed some 30 years ago in Finnmarksvidda, and summarised in Olesen \& Sandstad (1993), led to a simple stratigraphic model for the Kautokeino Greenstone Belt. The stratigraphy is best preserved on the more gently dipping eastern flank of the greenstone belt, where the contact between the underlying Jergul Complex and overlying Kautokeino Greenstone Belt can be shown to be stratigraphic (Solli, 1983). Along this flank, the gneiss of the Jergul Complex is successively overlain by the Goldenvárri (Gål'denvarri), Masi, Suolovuopmi and Likčá ( $L i k c ̌ c a)$ formations (Figs. 3, 5; Solli, 1983; Siedlecka et al., 1985; Olesen \& Sandstad, 1993; Torske \& Bergh, 2004). On the western flank of the Kautokeino Greenstone Belt, the Čáskejas (Čas'kejas, 


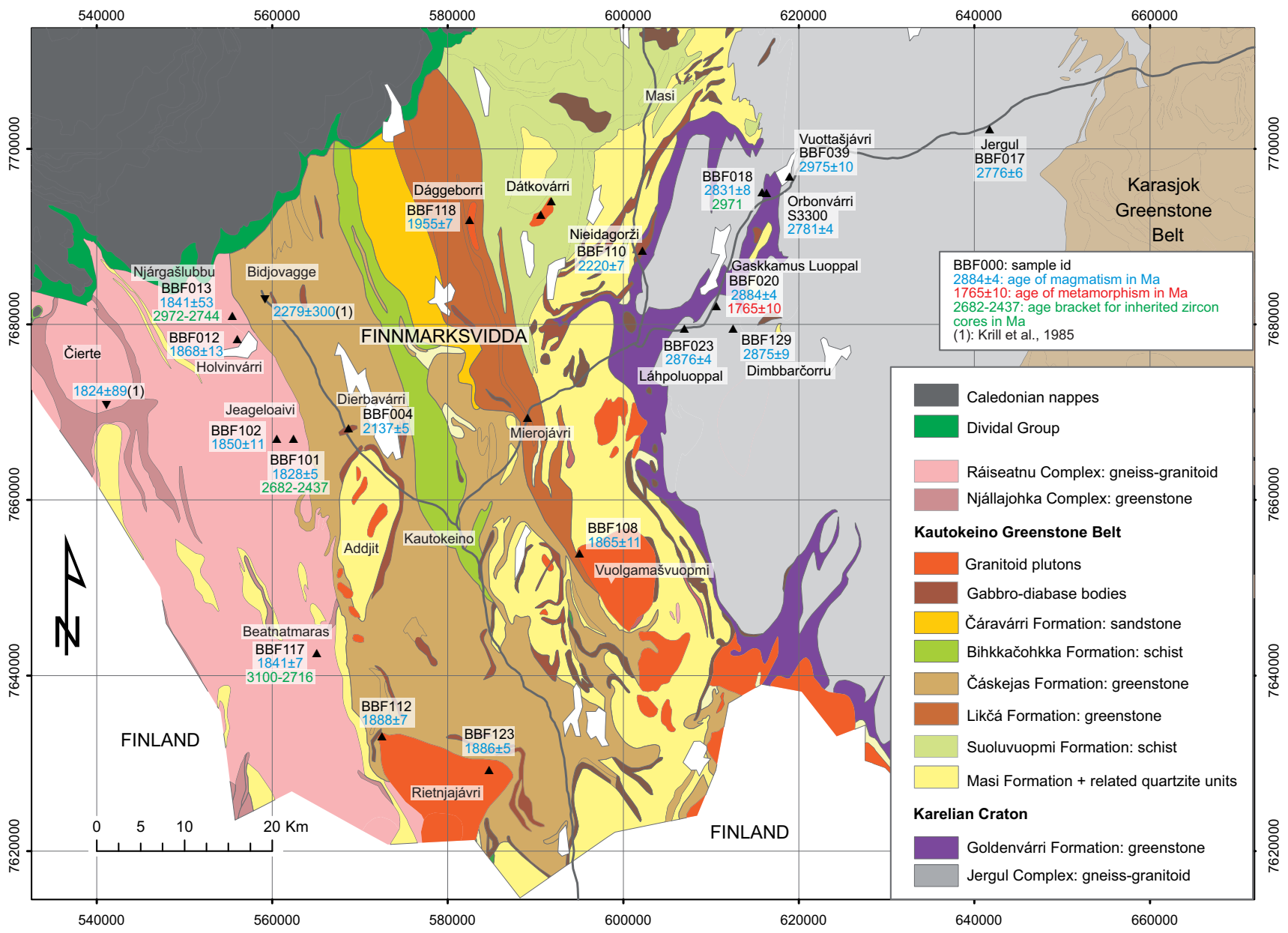

Figure 3. Simplified geological map of Finnmarksvidda, following Olesen \& Sandstad (1993) (UTM grid zone 34 in m). Sample locations are shown with a summary of geochronological results in Ma (colour coding: blue - age of magmatic crystallisation, red - age of metamorphism, green - age bracket for inherited zircon cores). The sampling of the Čáskejas Formation by Krill et al. (1985) is also located (whole-rock Sm-Nd errorchron age of $2279 \pm 300 \mathrm{Ma}$ ).

Časkijas) Formation is interpreted as a correlative of the Likčá Formation exposed in the eastern flank (Fig. 3). It is overlain by the Bihkkačohkka (Bik'kačåk'ka) and Čáravárri (Čaravarri) formations (Figs. 3, 5). These formations are described succinctly below together with the new geochronological data.

The structural architecture of Finnmarksvidda is well illustrated by the aeromagnetic map of the region (Fig. 2; Olesen et al., 1990; Olesen \& Sandstad, 1993; Henderson et al., 2015; Nasuti et al., 2015a, b). Two main structural domains or compartments are easily identified on the map (Olesen \& Sandstad, 1993; Henderson et al., 2015): a NE-SW-trending compartment in the northeast, covering the Jergul Complex and the northeastern part of the Kautokeino Greenstone Belt, and a NNWSSE-trending compartment in the west, covering the central and western part of the Kautokeino Greenstone Belt and the westernmost Ráiseatnu Complex. The NE-SWtrending compartment is characterised by long-wavelength magnetic anomalies and gently to moderately dipping structures. The NNW-SSE-trending compartment is linear and characterised by short-wavelength magnetic anomalies, a steep foliation and isoclinal folding. The pattern of magnetic anomalies shows a number of lowangular discontinuities inside the NNW-SSE-trending compartment highlighting several, steeply dipping, highstrain zones (Henderson et al., 2015). Structural interpretation of the magnetic map suggests that the NNW-SSEtrending structures cut and overprint the NE-SW structures, such that the former are younger.

In the north, the Kautokeino Greenstone Belt is unconformably covered by the Neoproterozoic-Cambrian, Dividal Group (Føyn, 1967; Andresen et al., 2014) and the Caledonian nappes of the Lower and Middle allochthons (Fig. 3; Roberts, 2003). Geological and aeromagnetic data (Figs. 1-3) suggest that the Kautokeino Greenstone Belt is concealed below the Caledonian orogenic prism to link some $50 \mathrm{~km}$ northwards with sedimentaryvolcanic successions exposed in the Alta-Kvænangen Tectonic Window and ultimately in the Repparfjord Tectonic Window (Reitan, 1963; Åm, 1975; Pharaoh et al., 1983, 1987; Olesen \& Sandstad, 1993; Melezhik et al., 2015a). Towards the south, the Kautokeino Greenstone Belt extends for a short distance along strike into 
600000

620000

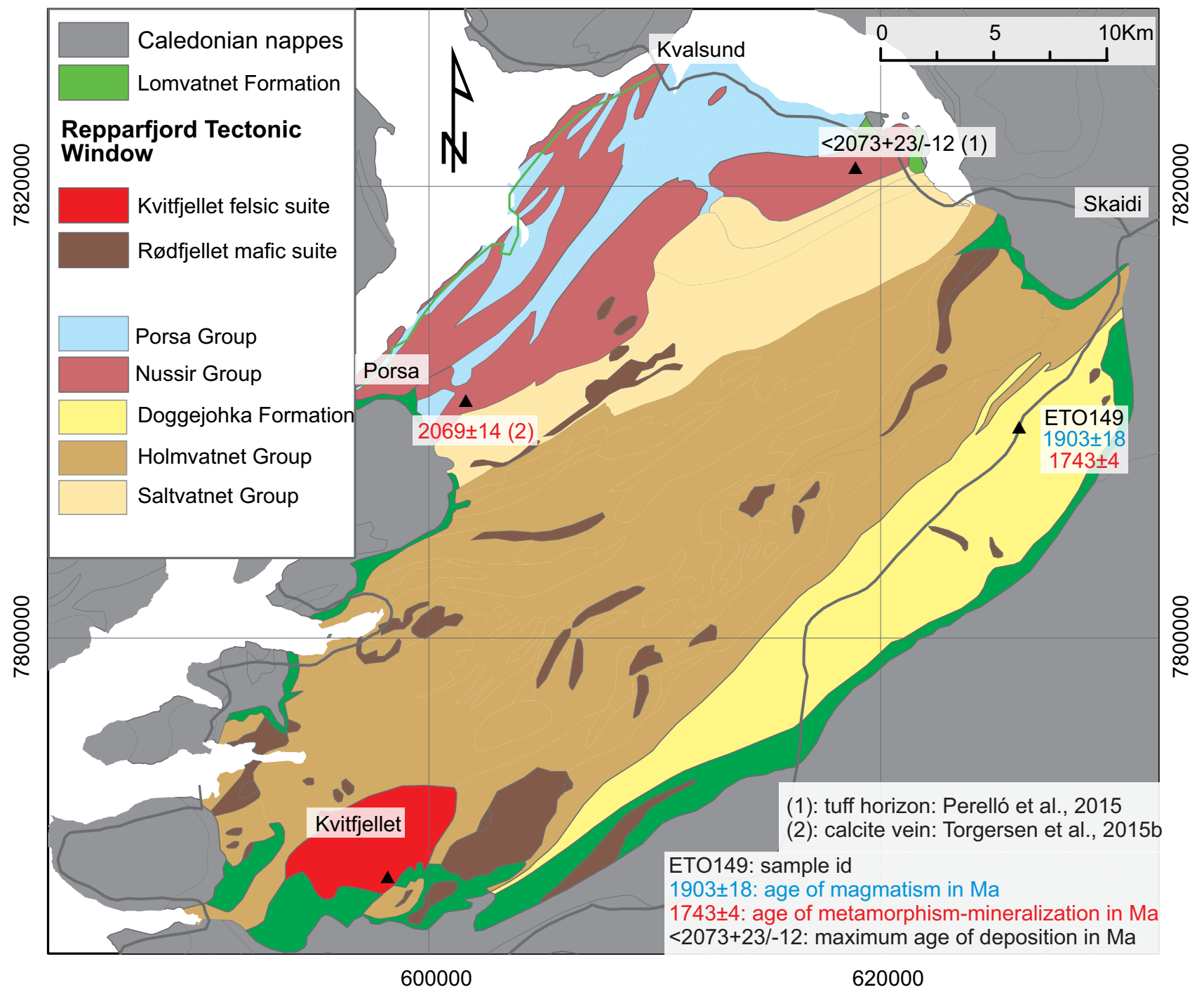

Figure 4. Simplified geological map of the Repparfjord Tectonic Window, following Torgersen et al. (2015a). Sample ETO149 and samples of Perelló et al. (2015) and Torgersen et al. (2015b) are located, with a summary of geochronological results (same colour coding as in Fig. 3).

Finland. Southwards, in Finland, the Central Lapland Greenstone Belt and Peräpohja Schist Belt are two large sedimentary-volcanic successions exposed along the western margin of the Karelian Craton (Fig. 1; Huhma et al., 1990; Lehtonen et al., 1998; Koistinen et al., 2001; Perttunen \& Vaasjoki, 2001; Rastas et al., 2001; Hanski \& Huhma, 2005; Ranta et al., 2015). Structurally, the NNWSSE-trending structures in the Kautokeino Greenstone Belt may link to the N-S-trending Pajala shear zone on the western side of the Central Lapland Greenstone Belt and Peräpohja Schist Belt (Lahtinen et al., 2015a; Ranta et al., 2015). Westwards, the Ráiseatnu Complex is separated from the Norbotten Craton by discontinuous greenstone belts (Fig. 1; Koistinen et al., 2001). These include the Lätäseno Group in Finland (Lauri \& Lepistö, 2014), connecting in the field to the thin Njállajohka (Njallajåkka) Complex near Čierte in Norway (Fig. 3; Fareth et al., 1977).

\section{Sampling and analyses}

Sampling was carried out in magmatic rocks collected at a broad regional scale in order to perform zircon $\mathrm{U}-\mathrm{Pb}$ geochronology (Table 1; Figs. 3, 4). A summary of the analytical methods is presented in Electronic Supplement 1. Samples were analysed for major and trace elements prior to crushing and zircon separation (Electronic Supplement 2). Zircon was analysed by Secondary Ion Mass Spectrometry (SIMS) at the NORDSIM laboratory (16 samples; Electronic Supplement 3; Whitehouse et al., 1999; Whitehouse \& Kamber, 2005) and by laser ablation inductively coupled plasma mass spectrometry (LA-ICP-MS) at the Geological Survey of Norway (3 samples; Electronic Supplement 4). In addition, ${ }^{40} \mathrm{Ar}-{ }^{39} \mathrm{Ar}$ analyses were performed on biotite from one sample at the Geological Survey of Norway (Electronic Supplement 5). 
In the following sections, geochronological data are reported from the base of the stratigraphic column upwards (Fig. 5). Zircon $\mathrm{U}-\mathrm{Pb}$ data are presented in the Tera-Wasserburg (inverse) concordia diagram. Errors are quoted at a $2 \sigma$ level. The core and rim of zircon were analysed if available, avoiding as much as possible fractures, altered (metamict) zones or interface between two zones. A thin (metamorphic) rim is observed in several samples, which is too thin to be analysed safely. No attempt was performed to analyse such rims. The weighted average ${ }^{207} \mathrm{~Pb} /{ }^{206} \mathrm{~Pb}$ age or alternatively the upper intercept age is selected as best age estimate for a zircon population.

\section{Archaean greenstone-gneiss association}

\section{Jergul Complex}

\section{Geological characteristics}

The Jergul Complex is an anticlinorium structure situated below and between the Kautokeino and Karasjok Greenstone Belts (Figs. 1, 3). On aeromagnetic maps, the Jergul Complex is characterised by two sets of anomalies: (1) pervasive, low-amplitude, NNE-SSW anomalies that are parallel to the main foliation in the Jergul Complex, and (2) NE-SW discontinuities interpreted as high-strain zones reworking the NNE-SSW trend (Fig. 2; Henderson et al., 2015). The Jergul Complex is a composite unit made of variably foliated felsic metaplutonic rocks of tonalitic, trondhjemitic, granodioritic and granitic composition (Fig. 7) and associated with mafic amphibolite bodies (Krill et al., 1985; Olsen \& Nilsen, 1985; Siedlecka et al., 1985; Pascal et al., 2010). Pegmatite and aplite dykes are common. The rocks range from compositionally homogeneous to heterogeneous at various scales. They are variably gneissic, layered, banded, veined and migmatitic. Substantial parts of the exposure of the Jergul Complex display very little visible fabric. The transition between gneiss and poorly foliated plutonic rock is generally gradual (Krill et al., 1985, and our own observations). Intrusive relationships between plutonic rocks and gneisses are difficult to determine unambiguously, either on the basis of field observations or using aeromagnetic data.

In the southern part of the complex, near the border with Finland, Olsen \& Nilsen (1985) mapped three felsic gneiss units: a structurally lower, brown, very foliated gneiss (Biennaroavvi gneiss), a light-coloured, finegrained, layered gneiss (Bissovárri gneiss), and a coarser gneiss with dots of biotite + amphibole (Áhkkanasvárri gneiss). Whole-rock $\mathrm{Rb}-\mathrm{Sr}$ data collected from two of these gneisses (Biennaroavvi and Áhkkanasvárri), from a c. $20 \mathrm{~km}$-long sampling area, gave a composite 19-point errorchron with a Mesoarchaean age of $2993 \pm 195 \mathrm{Ma}$ (Olsen \& Nilsen, 1985). On the basis of this information, the Jergul Complex was assigned an Archaean age on the existing geological map (Siedlecka et al., 1985; Olesen \& Sandstad, 1993; Koistinen et al., 2001). However, an homogeneous granite located at the northernmost end of the Jergul Complex gave a 6-point, whole-rock, RbSr errorchron, with an age of $2110 \pm 105 \mathrm{Ma}$ (Krill et al., 1985). Consequently, large areas of homogeneous plutonic rocks have been interpreted as Palaeoproterozoic plutons intruded into Archaean gneiss. They are represented in this way on geological maps and not mapped as part of the Jergul Complex (Olesen \& Sandstad, 1993). New U-Pb geochronological data reported below show that this interpretation is not correct.

\section{$\mathrm{U}-\mathrm{Pb}$ results}

Heterogeneous gneiss was sampled in the $c .720 \mathrm{~m}$-long borehole drilled at Vuottašjávri (Vuoddašjav'ri) (Fig. 3; Pascal et al., 2010). The borehole provided a low heatflow estimate of $c .40 \mathrm{~mW} / \mathrm{m}^{2}$ for the Jergul Complex, typical for an Archaean craton. The drillcore consists of interlayered felsic gneiss of tonalitic, granitic and trondhjemite composition and fine-grained amphibolite. Some pegmatite layers are present and garnet-bearing gneiss is rare. Sample BBF039 (Fig. 8A) was collected at a depth of $184 \mathrm{~m}$. The sample is representative of the interval between 124.5 and $188 \mathrm{~m}$, consisting of heterogeneous, veined, granitic-granodioritic gneiss with a few, metre-thick, fine-grained amphibolite intervals. BBF039 is a red, heterogeneous, quartz-rich, biotite granitic gneiss sample with $75 \% \mathrm{SiO}_{2}$. Zircon is prismatic to rounded with oscillatory zoning, and commonly a thin embayed rim. A few large zircon crystals are available and they are partly metamict and partly fractured. Thirty analyses were performed by LAICP-MS in 15 zircon crystals, avoiding fractures as much as possible. The rims are too thin to be analysed. The analyses define a discordia line with an upper intercept age of $2975 \pm 10 \mathrm{Ma}$, interpreted as the magmatic crystallisation age of the granite. An overlapping ${ }^{207} \mathrm{~Pb} /{ }^{206} \mathrm{~Pb}$ age of $2962 \pm 10 \mathrm{Ma}$ can be derived from the twelve more concordant analyses. The lower intercept age of $968 \pm 130 \mathrm{Ma}$ is probably meaningless.

An heterogeneous gneiss was also sampled in a large bedrock exposure east of the lake Gaskkamus Luoppal (Fig. 3), dominated by foliated, grey, tonalite-trondhjemite gneiss with diffuse compositional layering. Finegrained aplite veins, with sharp contacts to the host, are a volumetrically minor component that locally form dykes, 5-50 cm thick, cross-cutting the foliation. Sample BBF020 (Figs. 7, 8B) is a grey, fresh, equigranular, biotite-bearing tonalite-trondhjemite gneiss, with $70 \% \mathrm{SiO}_{2}$. The sample contains prismatic, tightly oscillatory-zoned zircon. Sixteen SIMS analyses of these yield a weighted average ${ }^{207} \mathrm{~Pb} /{ }^{206} \mathrm{~Pb}$ age of $2884 \pm 4 \mathrm{Ma}$, recording crystallisation of the tonalite-trondhjemite. A zircon overgrowth with no apparent internal zoning is visible bordering a few zircon crystals. Only one analysis of this overgrowth could be collected. It yields a ${ }^{207} \mathrm{~Pb} /{ }^{206} \mathrm{~Pb}$ 


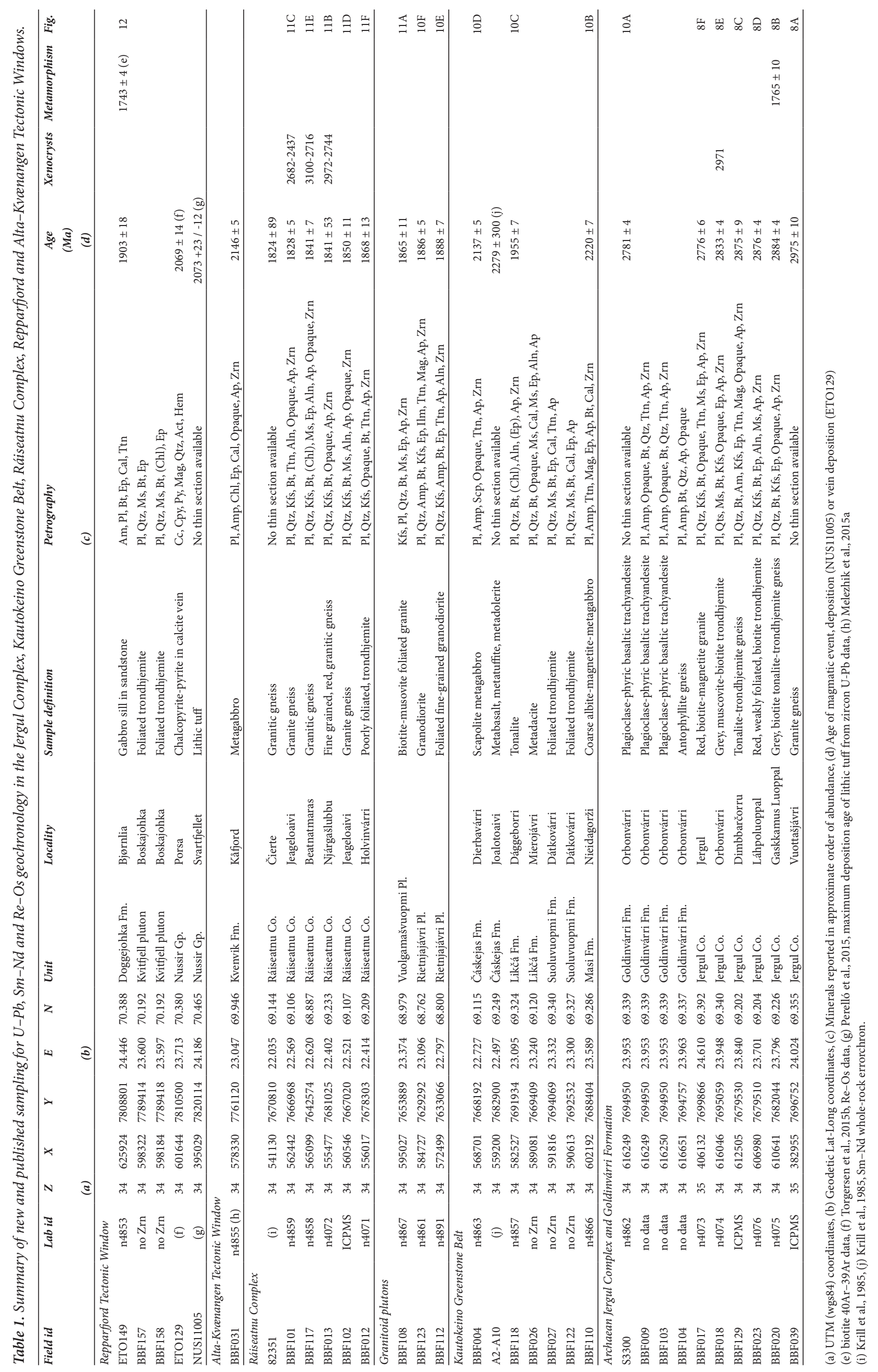


age of $1765 \pm 10 \mathrm{Ma}$, with a low $\mathrm{Th} / \mathrm{U}$ ratio typical for amphibolite-facies metamorphic crystallisation (Fig. 8B). The age of $1765 \pm 10 \mathrm{Ma}$ is our unique record of metamorphic zircon in the Jergul Complex. It suggests an amphibolite-facies metamorphic overprint, possibly related to the formation of the aplite veins observed at this locality and therefore possibly recording this event.

A locality of less heterogeneous granodioritic-trondhjemitic gneiss, lacking clear layering and veining, was sampled some $3 \mathrm{~km}$ from the previous locality at Dimbbarčorru (Fig. 3). Sample BBF129 (Figs. 7, 8C) is a medium-grained amphibolite-biotite gneiss $\left(\mathrm{SiO}_{2}=\right.$ $70 \%)$. The foliation is defined by centimetre-scale planar aggregates of quartz or mafic minerals. Zircon is prismatic and shows a simple oscillatory zoning commonly with few fractures. Sixteen zircon LA-ICP-MS analyses yield a monomodal distribution with an average ${ }^{207} \mathrm{~Pb} /{ }^{206} \mathrm{~Pb}$ age of $2875 \pm 9 \mathrm{Ma}$. This age records intrusion of the granodiorite-trondhjemite, within error of the age of nearby sample BBF020.

A poorly foliated trondhjemite-granite pluton, previously interpreted as a Proterozoic intrusive body (Olesen \& Sandstad, 1993), was sampled in a small quarry near Láhpoluoppal on the western side of the Jergul Complex (Fig. 3). The NE-facing quarry wall is dominated by poorly foliated trondhjemite and granite. A prominent, at least $4 \mathrm{~m}$-thick, steeply dipping, folded and highly foliated, biotite-rich layer is exposed in the wall and interpreted as a high-strain zone hosted in a dolerite dyke. Sample BBF023 (Figs. 7, 8D) was collected some $10 \mathrm{~m}$ northwest of the shear zone, in a poorly foliated rock volume, made of equigranular, medium-grained, red biotite trondhjemite. Fifteen SIMS U-Pb analyses of zircon define some scatter. Four analyses of oscillatory- to sector-zoned zircon cores with comparatively low U content $(<200 \mathrm{ppm})$ are concordant with a ${ }^{207} \mathrm{~Pb} /{ }^{206} \mathrm{~Pb}$ age of $2876 \pm 4$ Ma. Eight analyses of tips and cores, also oscillatory- to sector-zoned, are nearly concordant with dates spreading between $2853 \pm 11$ and $2806 \pm 12 \mathrm{Ma}$. Three additional analyses are largely discordant. There is no unique way of interpreting this dataset. The spread of data could be the consequence of some, variably sealed, fractures in the zircon crystals, visible on CL images. We propose to assign the crystallisation of the trondhjemite to the oldest group of concordant analyses with the age of $2876 \pm 4 \mathrm{Ma}$. This age overlaps with the age of the gneissic tonalite-trondhjemite samples BBF020 and BBF129 collected some $4-5 \mathrm{~km}$ to the northeast of BBF023.

At Orbonvárri (Fig. 3), a weakly foliated trondhjemite was interpreted by Solli (1983) as part of a $10 \mathrm{~km}$-wide Palaeoproterozoic pluton. Sample BBF018 (Figs. 7, 8E) is a medium-grained, grey, foliated, biotite-muscovite trondhjemite collected in a rather homogeneous exposure. Zircon is prismatic with fine oscillatory zoning. A significant proportion of the zircon crystals is metamict. Seventeen $\mathrm{U}-\mathrm{Pb}$ analyses were performed, and they define significant scatter. A group of four concordant analyses on nicely oscillatory-zoned zircon defines the intrusion age of the trondhjemite at $2833 \pm 4 \mathrm{Ma}$ $\left({ }^{207} \mathrm{~Pb} /{ }^{206} \mathrm{~Pb}\right.$ age $)$, while ten analyses on oscillatory-zoned but generally poorly luminescent zircon are younger and variably discordant. The intrusion age of $2833 \pm 4 \mathrm{Ma}$ indicates that the trondhjemite is an integral part of the Archaean Jergul Complex. One zircon crystal is clearly inherited and provides an age of $2971 \pm 4 \mathrm{Ma}$ (Fig. 8E), matching the age of $2975 \pm 10 \mathrm{Ma}$ of the granite gneiss in the Vuottašjávri borehole (sample BBF039; Fig. 8A). This suggests that the trondhjemite pluton either formed by remelting of a c. 2975 Ma source or assimilated such rocks during intrusion.

Weakly foliated plutonic rocks were also sampled near the Jergul settlement, where a large exposure of red, magnetite-biotite-bearing granite is available (Fig. 3). Sample BBF017 (Fig. 8F) was collected from the apparently most biotite-enriched facies, which is slightly porphyritic with $\mathrm{K}$-feldspar up to $1 \mathrm{~cm}$ long. In thin-section, the rock is deformed, as shown by small (c. $50 \mu \mathrm{m}$ in diameter) dynamically recrystallised grains of quartz
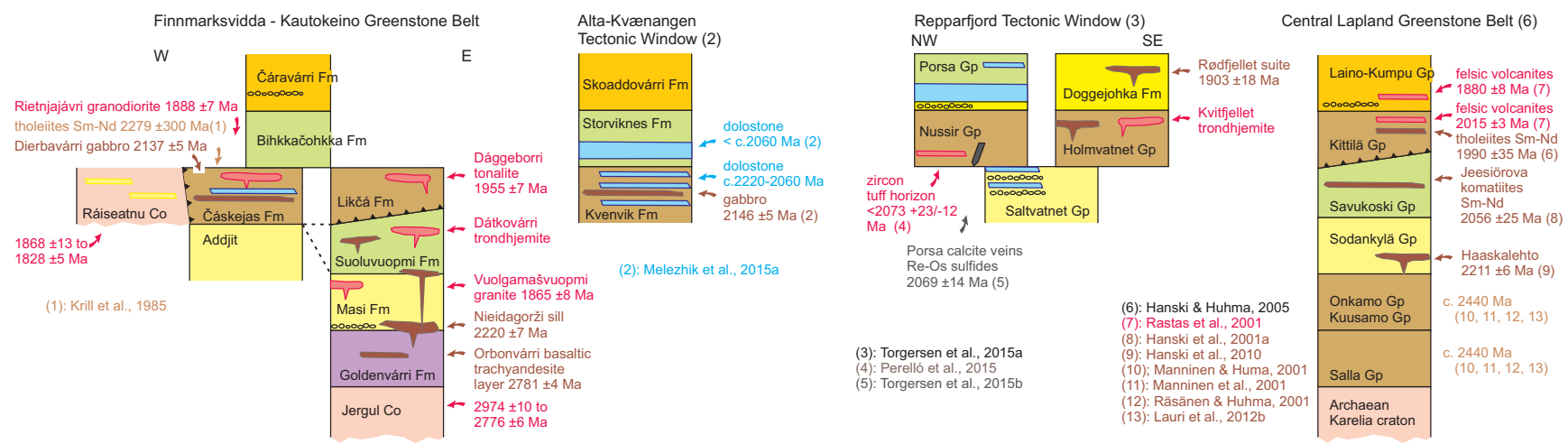

Figure 5. Lithostratigraphic model for Finnmarksvidda, the Alta-Kvonangen and Repparfjord tectonic windows, and the Central Lapland Greenstone Belt, with available geochronological constraints on deposition of the layered supracrustal rocks and on intrusion of plutonic rocks, from this work and published sources. Literature references numbered and listed inside the figure. 


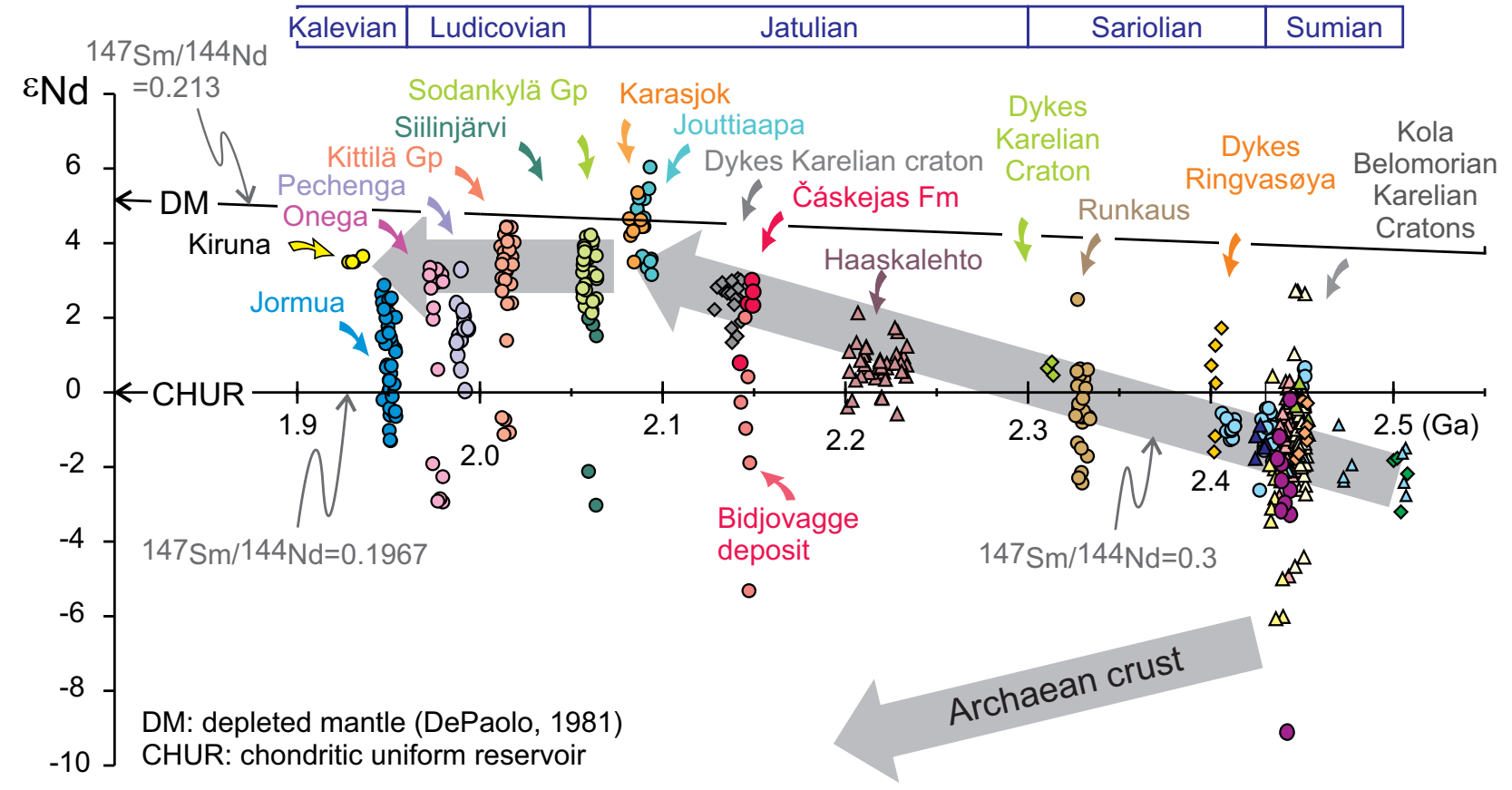

Figure 6. Timeline showing the geochronology and initial Nd isotopic composition $\left(\varepsilon_{N d}\right)$ of Palaeoproterozoic plutonic and volcanic rocks of mafic composition, in the Karelian, Norrbotten, Belomorian and Kola cratons, in the time interval between c. 2505 and 1930 Ma. Circles - volcanic rocks, triangles - plutonic rocks, diamonds - dykes. Each symbol represents one of 510 published Nd isotopic analyses at their recommended crystallisation age in Ma (to improve legibility, each symbol is assigned a random scatter lower than \pm 8 Ma along the age axis). Each unit is represented by a different colour: c. 2505-2441 Ma plutons from Kola (Balashov et al., 1993), c. 2450 Ma plutons from the Belomorian Craton (Lobach-Zhuchenko et al., 1998), c. 2450-2428 Ma plutons from the Karelian Craton (Huhma et al., 1990; Amelin \& Semenov, 1996; Perttunen \& Vaasjoki, 2001; Hanski et al., 2001b), c. 2450-2410 Ma volcanic rocks from Vetreny Belt (Puchtel et al., 1996, 1997), c. 2440 Onkamo Group volcanic rocks (Hanski \& Huhma, 2005), c. 2403 Ma Ringvassøy dykes (Kullerud et al., 2006), c. 2504, 2450, 2310 and 2140 Ma dykes in the Karelian Craton (Amelin \& Semenov, 1996; Mertanen et al., 2006; Stepanova et al., 2014, 2015), c. 2330 Ma Runkaus volcanic rocks in Peräpohja Schist Belt (Huhma et al., 1990), c. 2220 Ma Haaskalehto-type sills and dykes (Huhma et al., 1990; Hanski et al., 2010), $2137 \pm 5$ Ma amphibolite of Čáskejas Formation (deep pink; Krill et al., 1985) and davidite of the Bidjovagge deposit (pale pink; Bjørlykke et al., 1990) in the Kautokeino Greenstone Belt, c. 2090 Ma Jouttiaapa volcanic rocks in Peräpohja Schist Belt (Huhma et al., 1990), c. 2085 Ma komatiites in the Karasjok Greenstone Belt (Henriksen, 1983; Krill et al., 1985), c. 2060 Ma Siilinjärvi volcanic rocks (Lahtinen et al., 2015b), c. 2060 Ma Jeesiörova and Peuramaa komatiites in Savukoski Group in Central Lapland Greenstone Belt (Hanski et al., 2001a), c. 2015 Ma Kittilä Group volcanic rocks in Central Lapland Greenstone Belt (Hanski \& Huhma, 2005), c. 1990 Ma Pechenga ferropicrite and tholeiite volcanic rocks in Pechenga Belt (Hanski, 1992), $1976 \pm 9$ Ma Onega plateau volcanic rocks (Puchtel et al., 1998), c. 1950 Jormua ophiolite in Kainuu Schist Belt (Peltonen et al., 1996, 1998), c. 1932 Ma Kiruna Group in Kiruna Belt (Skiöld \& Cliff, 1984). Vectors for the model depleted mantle (DM) (DePaolo, 1981) and chondritic uniform reservoir (CHUR) as well as a typical vector for Archaean crust are shown. The regional stratigraphic systems (Sumian to Kalevian) are shown above the figure with their approximate time intervals, following Hanski \& Melezhik (2013).

and feldspar, between larger crystals. Short prismatic, oscillatory-zoned zircon is abundantly fractured, and commonly shows a low- $\mathrm{U}$ core. Twelve analyses of nonfractured zircon provide a good cluster with a ${ }^{207} \mathrm{~Pb} /{ }^{206} \mathrm{~Pb}$ age of $2776 \pm 6 \mathrm{Ma}$, recording intrusion of the granite.

\section{Interpretation}

The new data bracket intrusion of the magmatic protoliths of the Jergul Complex between $2975 \pm 10$ and $2776 \pm 6 \mathrm{Ma}$ (Figs. 3, 5). Detection of c. $2971 \mathrm{Ma}$ zircon xenocrysts in a c. $2833 \mathrm{Ma}$ trondhjemite (Fig. 8E) suggests that the Archaean crust of the Jergul Complex was affected by significant internal reworking or recycling during the 2975-2776 Ma time interval. Samples BBF020, BBF023 and BBF129, collected within a $6 \mathrm{~km}$ radius (Fig. 3), give overlapping intrusion ages at $2884 \pm$ 4, $2876 \pm 4$ and $2875 \pm 9$ Ma. Gneissic and nongneissic, foliated and nonfoliated, veined and nonveined rocks in this area have an overlapping intrusion age and probably belong to a single, variably reworked magmatic suite.

\section{Goldenvárri Formation}

\section{Lithostratigraphy}

The Goldenvárri Formation was identified and described by Solli (1983) as a separate greenstone unit associated with the Jergul Complex and underlying the prominent quartzite-dominated Masi Formation. The Goldenvárri Formation is estimated to be $1-1.5 \mathrm{~km}$ thick, although the base is not exposed. It consists mainly of fine-grained amphibolite, interpreted as metabasalt. Geochemically, the amphibolites are rich in $\mathrm{MgO}$ (up to $16 \mathrm{wt} . \%$ ) and $\mathrm{Cr}$ (mostly between 700 and $1200 \mathrm{ppm}$ ), but poor in $\mathrm{TiO}_{2}$ (mostly $<0.7$ wt.\%), reflecting a high degree of partial melting of the peridotite source (Fig. 9A, B). Rare-earth 
element (REE) abundance patterns are characterised by a moderate enrichment in light rare earth elements (LREE; Fig. 9C). The amphibolite comprises amphibole, plagioclase, biotite and titanite. It has a marked foliation that is generally parallel to the primary layering. Original volcanic features are uncommon, though volcanic breccias with mafic clasts are locally reported (Solli, 1983). The Goldenvárri Formation also contains metasedimentary rocks. These are mainly amphibolite-facies metapelites, i.e., mica schist locally containing garnet, staurolite and sillimanite.

At Orbonvárri (Fig. 3), the Goldenvárri Formation is well exposed along a $1 \mathrm{~km}$-long, across-strike, E-W transect (Solli, 1983). It mainly includes amphibolite, but also a c. $300 \mathrm{~m}$-thick interval of mica schist and mica-bearing metagreywacke. A $30 \mathrm{~m}$-thick horizon of anthophyllitecordierite rock is also known from Orbonvárri (sample BBF104, anthophyllite gneiss).

\section{$\mathrm{U}-\mathrm{Pb}$ results}

One c. $100 \mathrm{~m}$-long and $10 \mathrm{~m}$-thick layer of basaltic trachyandesite with plagioclase phenocrysts $\left(\mathrm{SiO}_{2}=53 \%\right.$; $\mathrm{Na}_{2} \mathrm{O}+\mathrm{K}_{2} \mathrm{O}=6.8 \%$; sample $\mathrm{BBF} 103$ ) is hosted in the fine-grained amphibolite and known to contain zircon (Solli, 1983). This layer is conformable with a locally sharp and generally gradual contact with the host amphibolite. The rock (samples BBF009 and BBF103) has variable amounts of plagioclase megacrysts, up to 5 $\mathrm{cm}$ long, preferentially oriented parallel to the foliation (Fig. 10A). The phenocrysts are generally pseudomorphs after plagioclase, and made of polycrystalline plagioclase aggregates. Some well preserved phenocrysts of plagioclase are up to $1 \mathrm{~cm}$ long, twinned and speckled with biotite. The megacrysts are hosted in an amphibolite matrix petrographically similar to the host amphibolite. The basaltic trachyandesite layer can be interpreted either as a volcanic rock, interlayered in the basaltic succession or as a deformed subvolcanic dyke. We prefer the latter interpretation, as the dated rock is geochemically distinct from the basaltic succession, including a distinctly more LREE-enriched REE pattern (Fig. 9C).

Zircon was recovered from a $30 \mathrm{~kg}$ sample, S3300, collected some 30 years ago at exactly this locality (Fig. 10A; Solli, 1983). The zircons are small (few larger than 100 $\mu \mathrm{m})$ and fractured. They are prismatic to rounded with oscillatory to sector zoning. Some crystals with convolute zoning suggest that zircon was affected by a thermal overprint and partial recrystallisation (Hoskin \& Black, 2000). Some crystals show a thin rim. Thirteen SIMS zircon $\mathrm{U}-\mathrm{Pb}$ analyses are concordant to near-concordant (Fig. 10A). They define some scatter. The nine oldest analyses, mostly on oscillatory- to sector-zoned material, provide a good ${ }^{207} \mathrm{~Pb} /{ }^{206} \mathrm{~Pb}$ age of $2781 \pm 4 \mathrm{Ma}(\mathrm{MSWD}=$ $0.75)$. This age is regarded to record the magmatic crystallisation of the basaltic trachyandesite.

\section{Interpretation}

At Orbonvárri, the dated basaltic trachyandesite layer
(S3300; Fig. 10A) can be interpreted as a metavolcanic rock interlayered in the sequence, or, more conservatively, as a (derformed) dyke or sill. In the former interpretation, its age of $2781 \pm 4 \mathrm{Ma}$ is representative for the entire mafic metavolcanic succession of the Goldenvárri Formation, whereas in the latter interpretation, its age corresponds to a minimum age for deposition of the volcanic succession.

The metavolcanic fine-grained amphibolite abuts westwards the grey, foliated, trondhjemite dated at $2833 \pm$ $4 \mathrm{Ma}$ (sample BBF018; Fig. 8E), which is undisputably a metaplutonic rock. The contact between the two lithologies is generally conformable, sharp and decorated by quartz veins. About $10 \mathrm{~m}$ east of the contact, a layer of trondhjemite is observed in the amphibolite, and west of the contact, layers of amphibolite are observed inside the trondhjemite. The contact can be interpreted as either tectonic (fault zone sealed by quartz veins) or depositional (volcanic rocks overlying plutonic rocks). If the dated basaltic trachyandesite layer (S3300) is interpreted as a dyke or a sill in the volcanic succession and the contact as depositional, then the volcanic succession is bracketed between the trondhjemite basement (2833 $\pm 4 \mathrm{Ma}$; Fig. 8E) and the dyke (2781 $\pm 4 \mathrm{Ma}$; Fig. 10A). Independently of the detailed interpretation of these field relationships, the Goldenvárri Formation can be safely regarded as an Archaean greenstone formation associated with the Jergul Complex (Figs. 3, 5).

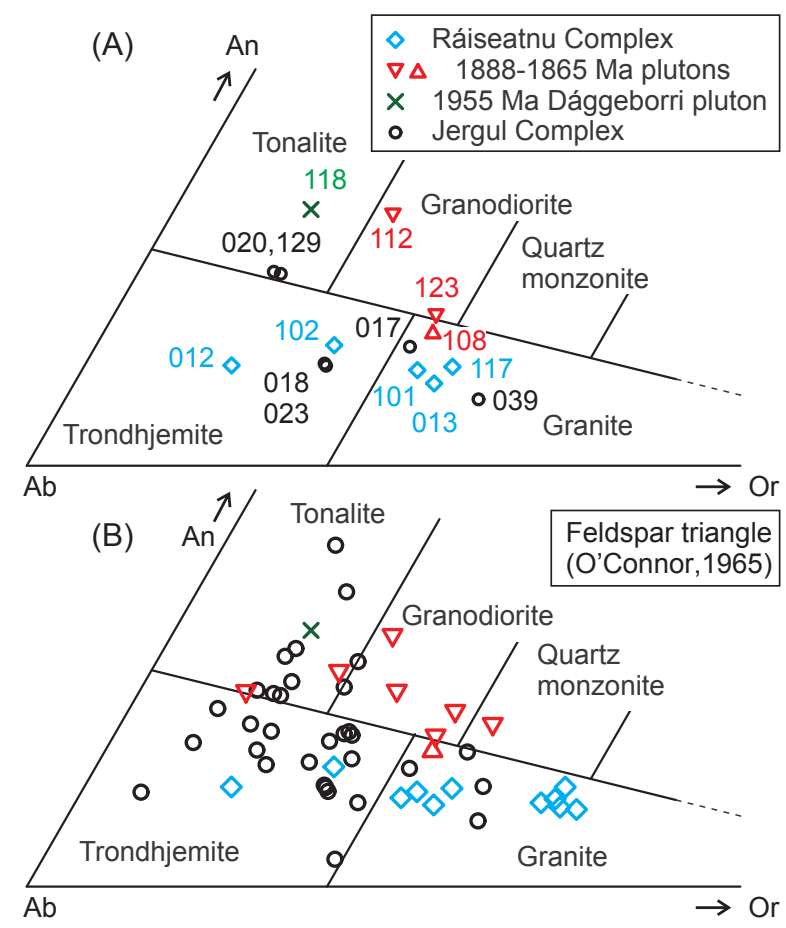

Figure 7. Granitoid classification of O'Connor (1965) with samples from Finnmarksvidda (normative albite-orthoclase-anorthite ternary plot for rocks with normative quartz $>10 \%$ ). (A) Samples of this study (with last three digits of sample identifier). (B) Samples of this study and Olsen \& Nilsen (1985). 


\section{Palaeoproterozoic Kautokeino Greenstone Belt}

\section{Masi Formation and albitised mafic sills}

\section{Lithostratigraphy}

In the Masi area (Fig. 3), the quartzite-dominated Masi Formation overlies the Goldenvárri Formation (Solli, 1983; Siedlecka et al., 1985). At several localities, a typically $5 \mathrm{~m}$-thick conglomerate is observed at the base of the Masi Formation. The conglomerate contains pebbles generally less than $5 \mathrm{~cm}$ in diameter of granitic gneiss, quartz and quartzite. The bulk of the Masi Formation consists of white, grey or pink quartzite, feldspathic quartzite and meta-arkose, with some conglomerate layers. The rock contains minor, coarse-grained, metamorphic biotite and garnet. In places, the quartzite contains fuchsite, imparting a green colour to the rock. Primary sedimentary structures are locally well preserved, including metre-scale, trough cross-bedding of possible aeolian origin. Lithologically and stratigraphically, the Masi Formation correlates with the Skuvvanvárri Formation at the base of the Karasjok Greenstone Belt (Often, 1985; Siedlecka et al., 1985; Braathen \& Davidsen, 2000) and possibly with the Addjit quartzite exposed in an anticline in the western part of the Kautokeino Greenstone Belt (Figs. 2, 3; Olsen \& Nilsen, 1985).

Several albitised mafic sills, also known as albite diabase, are emplaced within the Masi Formation and along the contact between the Masi and the underlying Goldenvárri Formation (Fig. 3). They are rich in magnetite and characterised by prominent positive magnetic anomalies (e.g., Nieidagorži sill in Fig. 2). In the area around Masi, at least two, large, NE-SW-trending sills, each approximately $800 \mathrm{~m}$ thick, can be mapped. They may be either part of a single intrusion or separate intrusions. One of the two sills, the Nieidagorži sill, overlapping the contact between the Goldenvárri and Masi formations, was dated by Krill et al. (1985). They obtained a discordant array of $\mathrm{U}-\mathrm{Pb}$ analyses of bulk zircon fractions performed by isotope dilution thermal ionisation mass spectrometry (ID-TIMS), with an upper intercept age of $1815 \pm 24 \mathrm{Ma}$. Consequently they interpreted this body as a late Svecokarelian intrusion. New data show that this interpretation is not correct.

\section{$\mathrm{U}-\mathrm{Pb}$ results}

We revisited the locality of the Nieidagorži sill of Krill et al. (1985). The body is foliated at the margin and unfoliated in the centre, where the rock is medium- to coarsegrained (up to $10 \mathrm{~mm}$ grain size). Diffuse layering and ghosts of subophitic texture can be recognised, and sulphide-rich pods are locally observed. The magmatic rock is transformed into a rather leucocratic metasomatic rock with an assemblage of albite, amphibole, titanite and magnetite (Table 1). Petrographically, magnetite seems to be preserved from the magmatic assemblage, while other major phases are secondary. Sample BBF110 (Fig. $10 \mathrm{~B})$ is a coarse-grained facies in the centre of the sill. A few prismatic zircons were recovered. They are poorly luminescent, fractured, partly porous or rich in inclusions, and are therefore largely metamict. However, less altered zones exhibiting a prismatic oscillatory growth zoning are also present and these clearly associate zircon growth to the magmatic crystallisation of the sill. Twelve $\mathrm{U}-\mathrm{Pb}$ analyses were collected with SIMS in ten zircons targetting the less altered material. They are rich in $U$ (c. $300 \mathrm{ppm}$ ) and have a high $\mathrm{Th} / \mathrm{U}$ ratio (3.5), typical for magmatic zircon. Four of the analyses are concordant and eight of the analyses define a good discordia line. The upper intercept age of $2220 \pm 7 \mathrm{Ma}(\mathrm{MSWD}=1.3$ ) is regarded as the age of intrusion of the Nieidagorži sill. The lower intercept age of $c .415$ Ma records Caledonian episodic $\mathrm{Pb}$ loss.

\section{Interpretation}

The age of $2220 \pm 7 \mathrm{Ma}$ for the Nieidagorži sill is much older than the date of $1815 \pm 24 \mathrm{Ma}$ obtained by Krill et al. (1985). The new age estimate is more robust and therefore supercedes the previous one. As discussed below, the new age recalibrates the whole regional lithostratigraphy (Fig. 5). It provides a lower bracket for the deposition of the host Masi Formation. The quartzite was thus deposited between $2781 \pm 4 \mathrm{Ma}$ (deposition of Goldenvárri Formation; Fig. 10A) and $2220 \pm 7 \mathrm{Ma}$ (intrusion of the sill; Fig. 10B). The local occurrence of fuchsite in the Masi quartzite is a logical consequence of a basement-cover relationship between the the Cr-rich greenstone of the Goldenvárri Formation and the Masi Formation (Figs. 3, 5, 9).

\section{Suoluvuopmi Formation}

The Masi Formation is overlain by the Suoluvuopmi Formation (Figs. 3, 5), which consists of mica schist, finegrained amphibolite, minor graphite schist, local albitequartz rock (albite felsite) and local (meta)komatiite (Mg-rich chlorite rocks; Solli, 1983; Olesen \& Sandstad, 1993). The contact betwen the Masi and Suoluvuopmi formations is commonly deformed. However, at several localities, it can be interpreted as a conformable stratigraphic boundary (Solli, 1983). Mafic sills similar to the Nieidagorži sill (Fig. 10B) cross-cut the Suoluvuopmi Formation (Solli, 1983). This suggests that deposition of the Suoluvuopmi Formation is also older than $2220 \pm 7$ Ma.

Mica schist of the Suoluvuopmi Formation hosts a conformable, flat-lying, weakly foliated trondhjemite sill, at Dátkovárri, in the northern part of the Kautokeino Greenstone Belt (Fig. 3; Holmsen et al., 1957). A poorlyreliable, 5-point, whole-rock $\mathrm{Rb}-\mathrm{Sr}$ errorchron of 1827 $\pm 323 \mathrm{Ma}$ was proposed by Krill et al. (1985) for intrusion of this body. Attempts to separate zircon from two 
samples of biotite-muscovite trondhjemite from this sill (BBF027 and BBF122) were, unfortunately, unsuccessful.

\section{Likčá Formation}

\section{Lithostratigraphy}

The contact between the Suoluvuopmi Formation and the Likčá Formation corresponds to the main stuctural discontinuity bounding the NNW-SSEtrending structural compartments defined by structural interpretation of the aeromagnetic map (Fig. 2; Henderson et al., 2015). In the field, it corresponds to a steep, west-dipping, dip-slip shear zone. The Likčá Formation has been interpreted as stratigraphically overlying the Suoluvuopmi Formation (Siedlecka et al., 1985). However, following the above structural interpretation, this may not be correct.

The Likčá Formation consists of low-grade, mafic metavolcanic lava, tuffites and dolerites of tholeiitic composition, with minor layers of graphite schist, mica schist, sandstone, dolostone and albite-quartz rocks (Siedlecka et al., 1985; Olesen \& Sandstad, 1993). It is associated with a positive residual Bouguer anomaly, implying a substantial thickness of mafic rocks (Olesen \& Sandstad, 1993). One layer of fine-grained, finely laminated, magnetite-bearing felsic schist is a marker horizon, distinguished by a strong and thin, c. 40 km-long, NNW-SSE-trending magnetic anomaly. This layer is interpreted as a metadacite. Unfortunately, no zircon could be recovered from one sample (BBF026, $63 \% \mathrm{SiO}_{2}$ ) collected close to the settlement of Mierojávri (Fig. 3), preventing direct dating of the deposition of the Likčá Formation.

\section{$\mathrm{U}-\mathrm{Pb}$ results}

The Dággeborri tonalite pluton is a small, N-S-trending, c. $5 \mathrm{~km}$-long and $800 \mathrm{~m}$-wide plutonic sheet hosted in mafic volcanic rocks of the Likča Formation. The rock contains subautomorphic plagioclase, $c .5 \mathrm{~mm}$ long, with ghost oscillatory growth zoning, together with quartz, biotite and allanite. The texture suggests a shallow subvolcanic level of intrusion. The magmatic mineralogy is largely altered, as evident from saussuritisation of feldspar, and the presence of secondary chlorite, calcite and epidote. Although the rock is apparently unfoliated, it shows partial dynamic recrystallisation of quartz and biotite leading to diffuse grain-size reduction, and the outcrop displays at least two systematic sets of conjugate fractures.

Sample BBF118 (Figs. 7, 10C) is a tonalite collected in a comparatively little fractured outcrop of the Dággeborri pluton. The sample contains large, well terminated prismatic zircon crystals, with short-wavelength oscillatory zoning and common inclusions of quartz and feldspar. Twelve SIMS U-Pb analyses in the central and marginal zones of the crystals yield an upper intercept age of 1955 $\pm 7 \mathrm{Ma}$, constraining the age of intrusion of the tonalite, and a lower intercept at c. $372 \mathrm{Ma}$.

\section{Interpretation}

The age of $1955 \pm 7$ Ma for the Dággeborri pluton (Fig. 10C) offers a minimum age for extrusion of the mafic volcanic rocks of the Likčá Formation. Arguably, the tonalitic signature could suggest that the pluton formed above a subduction zone, before the Svecokarelian orogeny.

\section{Čáskejas Formation}

\section{Lithostratigraphy}

The Čáskejas Formation is located in the western part of the Kautokeino Greenstone Belt (Fig. 3). It is correlated with the Likća Formation, and it also is associated with a positive residual Bouguer anomaly (Olesen \& Sandstad, 1993). It mainly consists of fine- to medium-grained, mafic metavolcanic and metatuffite, folded and metamorphosed in greenschist- to amphibolite-facies conditions and commonly albititised or scapolitised. The metavolcanic rocks have a subalkaline tholeiitic composition (Fig. 9A) and display REE patterns ranging from flat to slightly enriched in light REEs (Fig. 9D). The volcanic rocks contain abundant conformable bodies of metadolerite and metagabbro with similar geochemical signatures (Sandstad, 1984). The age of extrusion of the mafic volcanic rocks in the Ćáskejas Formation has been estimated at $2279 \pm 300 \mathrm{Ma}$, by means of a 5-point, Sm$\mathrm{Nd}$, whole-rock errorchron in amphibolite (metabasalt, metatuffite and metadolerite), collected c. $4 \mathrm{~km}$ south of the abandoned Bidjovagge mine (Fig. 3, at Joalotoaivi; Krill et al., 1985).

The mafic rocks are interlayered with thin layers of schist, graphite schist, dolostone and albite-quartz rocks (Sandstad, 1985; Siedlecka et al., 1985; Olesen \& Sandstad, 1993). The sequence is strongly deformed with a penetrative steep foliation, isoclinal folding and numerous shear zones (Sandstad, 1985; Bjørlykke et al., 1987; Nilsen \& Bjørlykke, 1991; Henderson et al., 2015), and the stratigraphic polarity can therefore not be ascertained. The most straightforward interpretation is that the lower part of the formation is exposed in the west, where the Ćáskejas Formation abuts the Ráiseatnu Complex or is in contact with the Addjit quartzite antiform (Fig. 3). The upper part is exposed in the east, where the amount of shale becomes progressively more important, metamorphic grade decreases from amphibolite to greenschist facies and pillow lavas are in places well preserved (Sandstad, 1985; Siedlecka et al., 1985).

\section{$\mathrm{U}-\mathrm{Pb}$ results}

A conformable metagabbro body is exposed in a small quarry near Dierbavárri, in the lower part of the Čáskejas Formation, north of the contact with the Addjit quartzite antiform (Fig. 3). The metagabbro body contains 
patchy aggregates of amphibole up to $3 \mathrm{~cm}$ in length. Diffuse metre-scale layering defined by variation in the size of these amphibole aggregates suggests that they reflect an original magmatic grain size as part of an originally ophitic texture and that the metagabbro represents a layered magmatic sill. The outcrop is characterised by pockets and veins of albitite and the rock is metasomatised with diffuse alibitisation and scapolitisation. Sample BBF004 (Figs. 3, 10D) is collected from a layer with coarse, c. $2 \mathrm{~cm}$, weakly foliated aggregates of amphibole. Petrographically, the mineralogy of the rock is met- amorphic in origin and dominated by hornblende, plagioclase and scapolite (Table 1). The rock contains a small amount of coarse prismatic zircon up to $200 \mu \mathrm{m}$ long. The zircon crystals are sector-zoned, with weak cathodoluminescence. They are most commonly fractured and metamict, and rich in inclusions. Eight out of eleven SIMS U-Pb analyses of nonmetamict sectorzoned zircon define a robust cluster with a weighted average ${ }^{207} \mathrm{~Pb} /{ }^{206} \mathrm{~Pb}$ age of $2137 \pm 5 \mathrm{Ma}$. This age records magmatic intrusion of the gabbro body.
Zircon U-Pb data, Jergul Complex
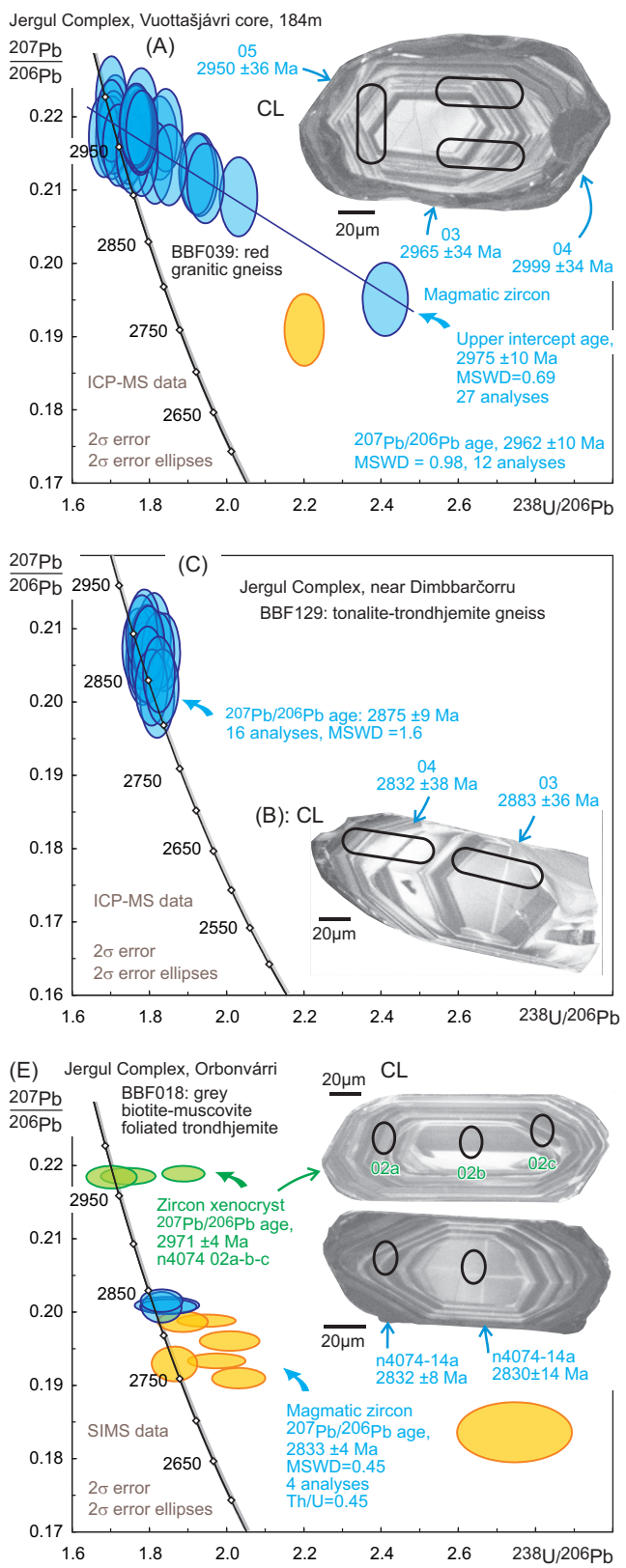
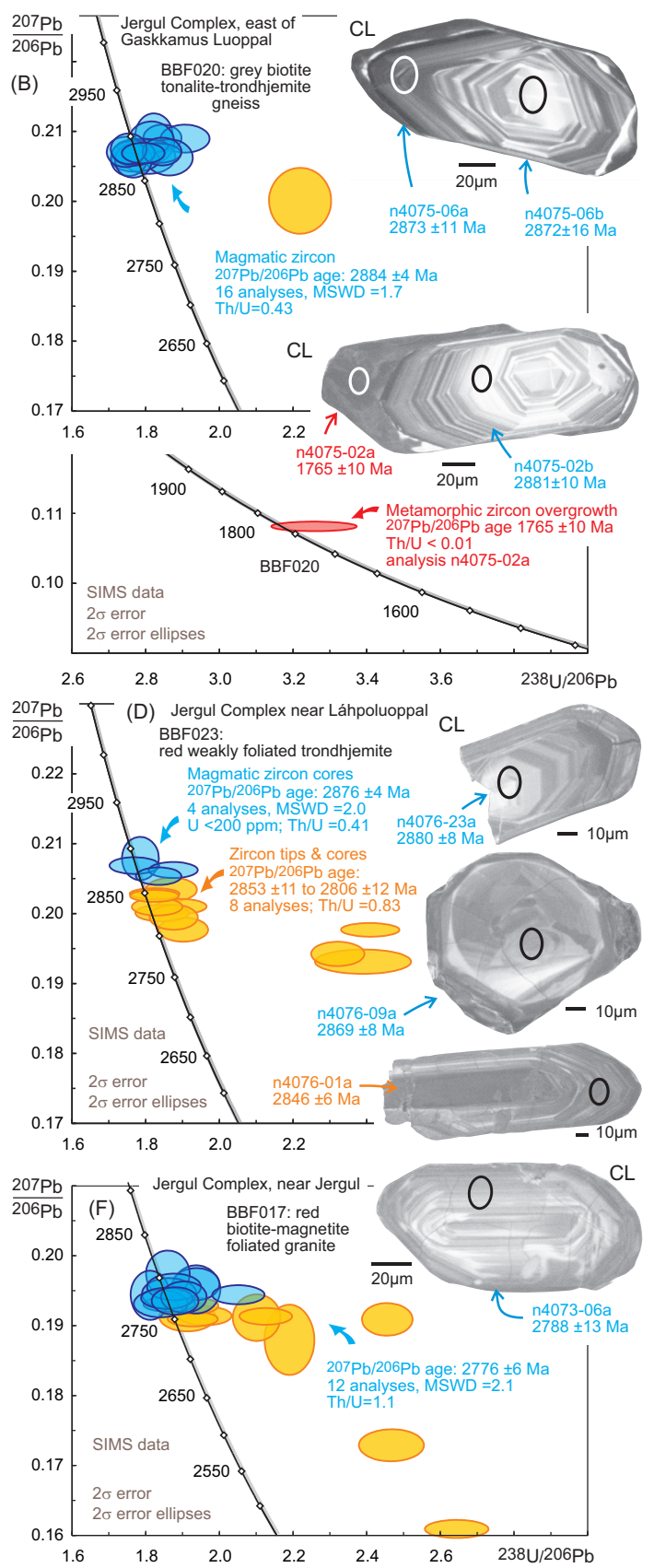

Figure 8. Zircon $U-P b$ data for samples of the Jergul Complex: Tera-Wasserburg concordia diagram and CL images for selected zircons, with position of microanalyses. (A) sample BBF039, (B) BBF020, (C) BBF129, (D) BBF023, (E) BBF018, (F) BBF017. Colour coding: blue - selected analyses recording magmatic events, red - selected analyses recording metamorphism, green - analyses of inherited material, yellow - analyses not selected. Figure generated with ISOPLOT software (Ludwig, 2001). 


\section{Interpretation}

The deformation and outcrop conditions of the Čáskejas Formation do not allow us to determine the original magmatic relations between the plutonic and volcanic rocks. Both have similar geochemistry (Sandstad, 1984), and probably the dolerite and gabbro bodies can be regarded as subcontemporaneous sills in the metavolcanic succession, recording the same magmatic event. In this interpretation, the age of $2137 \pm 5 \mathrm{Ma}$ for the Dierbavárri gabbro dates the mafic magmatism of the Čáskejas Formation.

The age of $2137 \pm 5 \mathrm{Ma}$ for mafic plutonism in the Ćáskejas Formation is consistent with the Sm-Nd, whole-rock, 5-point errorchron age of $2279 \pm 300 \mathrm{Ma}$ by Krill et al. (1985) for mafic metavolcanic rocks, within analytical error. The large uncertainty on the Sm-Nd errorchron is a consequence of the low spread of the $\mathrm{Sm} / \mathrm{Nd}$ ratio $\left(0.156<{ }^{147} \mathrm{Sm} /{ }^{144} \mathrm{Nd}<0.198\right)$, rather than of reworking processes.

\section{Bihkkačohkka and Čáravárri formations}

The Čáskejas Formation is overlain by the Bihkkačohkka and Ćáravárri formations towards the centre of the Kautokeino Greenstone Belt (Figs. 3, 5; Siedlecka et al., 1985). The Bihkkačohkka Formation (1-1.5 km thick) divides into a lower arkosic sandstone and an upper shale. The Ćáravárri Formation (c. $4 \mathrm{~km}$ thick) is composed of arkosic sandstone, quartzite and conglomerate, with layers of shale (Torske \& Bergh, 2004). Probably belonging to the Ćáravárri Formation is a polymict conglomerate with pebbles of greenstone, quartzite, albitite and limestone-dolostone, which is exposed in the town of Kautokeino (UTM Z34, E: 582035, N: 7657685). The transition between the Č́skejas and Bihkkačohkka formations is apparently conformable and progressive (Sandstad, 1985), whereas the transition between the Bihkkačohkka and Čáravárri formations is sharp. There is no direct constraint today on the timing of deposition of the Bihkkačohkka and Čáravárri formations. Following Torske \& Bergh (2004), the Čáravárri Formation

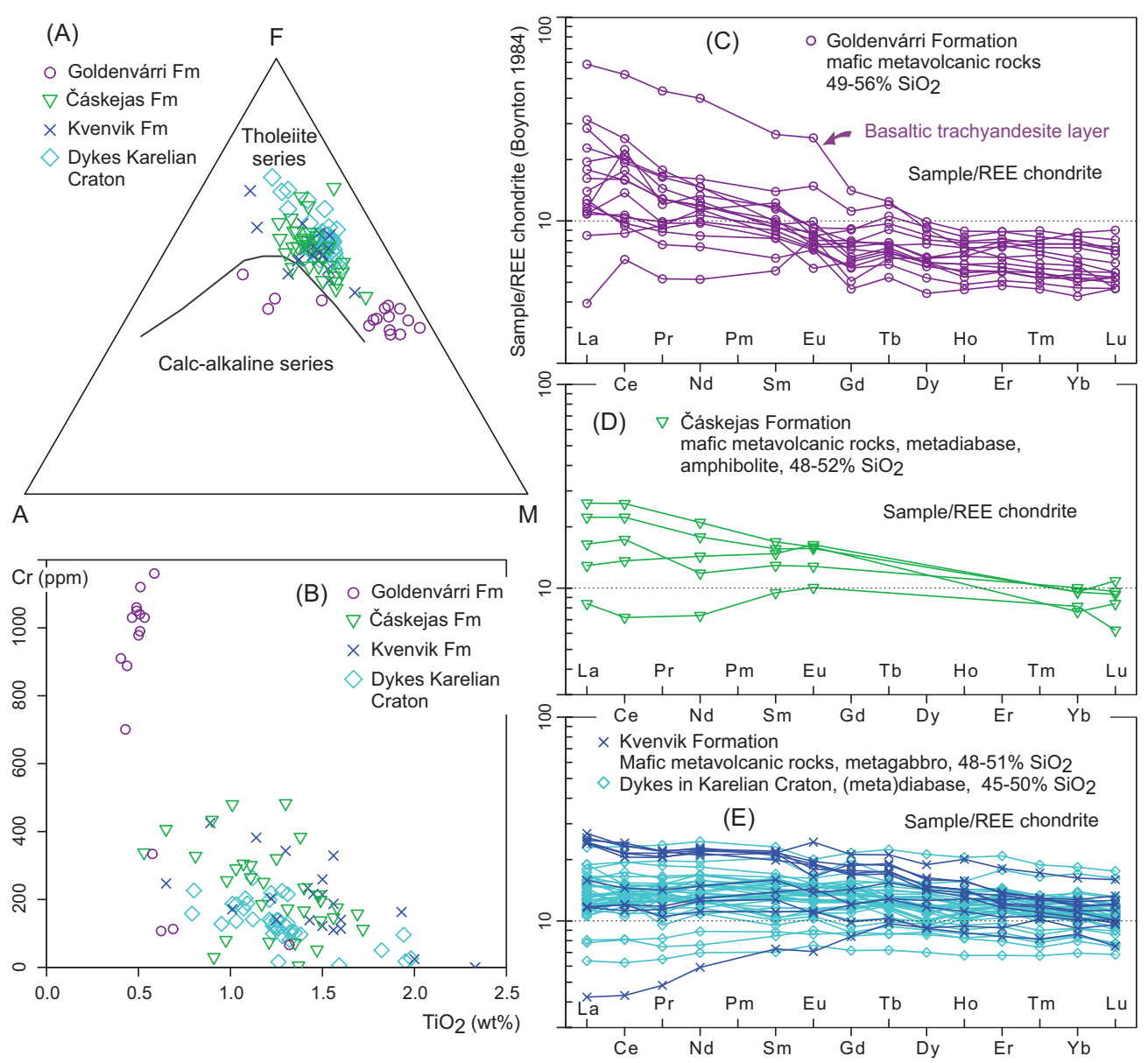

Figure 9. Whole-rock composition of mafic magmatic rocks of the Archaean Goldenvárri Formation (Solli, unpublished data), c. 2137 Ma Čáskejas Formation in the Kautokeino Greenstone Belt (data of Sandstad, 1984; Krill et al., 1985), c. 2146 Ma Kvenvik Formation in the AltaKvenangen Tectonic Window (data of Bergh \& Torske, 1988; Melezhik et al., 2015a) and c. 2140-2126 Ma mafic dykes in the Karelian Craton in Finland and Russia (data of Stepanova et al., 2014). (A) AFM ( $\left.\mathrm{A}-\mathrm{K}_{2} \mathrm{O}+\mathrm{Na}_{2} \mathrm{O}, \mathrm{F}-\mathrm{FeO} \mathrm{tot}_{2} \mathrm{M}-\mathrm{MgO}\right)$ diagram. (B) $\mathrm{TiO}$, vs. Cr diagram. (C), (D), (E) Rare-earth elements (REE) normalised to chondrites (Boynton, 1984). For the Čáskejas Formation, analyses of elements between $G d$ and Tm are below the detection limit. Figure generated with GCDKit software (Janoušek et al., 2006). 
represents a Svecokarelian foreland-basin deposit, including submarine, near-shore and fluviatile facies, fed from the east. In this model, it would have been deposited in front of a west-verging Svecokarelian orogenic wedge.

\section{Large granitoid plutons}

\section{Rietnjajávri granodiorite pluton}

The Rietnjajávri granodiorite pluton is a large pluton hosted in the Čáskejas Formation, in the southern part of the Kautokeino Greenstone Belt (Fig. 3; Olsen \& Nilsen, 1985). It is well delineated by a $16 \times 10 \mathrm{~km}$ anomaly on the aeromagnetic map, characterised by a more homogeneous magnetic signature than the surrounding greenstone (Fig. 2; Olesen \& Sandstad, 1993; Henderson et al., 2015). The pluton is dominated by weakly foliated metaluminous quartz monzonite, granodiorite and tonalite (Fig. 7; Olsen \& Nilsen, 1985). A 10-point, whole-rock, $\mathrm{Rb}-\mathrm{Sr}$ errorchron gave an age of $1821 \pm 143$ $\mathrm{Ma}$, interpreted as the intrusion age of the pluton (Krill et al., 1985).

The Rietnjajávri pluton was sampled at two localities $c .8$ $\mathrm{km}$ apart (Fig. 3). Sample BBF112 (Figs. 7, 10E) is a fresh, fine-grained, weakly foliated, equigranular amphibolebiotite granodiorite with abundant titanite. The sample contains prismatic, oscillatory-zoned, low-U zircon with few fractures. Twelve SIMS U-Pb analyses in eleven zircon crystals are concordant and well clustered. They yield a weighted average ${ }^{207} \mathrm{~Pb} /{ }^{206} \mathrm{~Pb}$ age of $1888 \pm 7 \mathrm{Ma}$. Sample BBF123 (Figs. 7, 10F) is a nonfoliated amphibole-biotite granodiorite, characterised by some large titanite crystals (1-2 mm) and spherical aggregates of amphibole (2-3 $\mathrm{mm})$, giving a spotted appearance to the rock. The plagioclase is largely saussuritised. This sample contains a population of oscillatory-zoned zircon. Twelve concordant and clustered $\mathrm{U}-\mathrm{Pb}$ analyses yield a weighted average ${ }^{207} \mathrm{~Pb} /{ }^{206} \mathrm{~Pb}$ age of $1886 \pm 5 \mathrm{Ma}$. The two age estimates for samples BBF112 and BBF123 are equivalent, with a weighted average ${ }^{207} \mathrm{~Pb} /{ }^{206} \mathrm{~Pb}$ age of $1887 \pm 4$ $\mathrm{Ma}$, supporting the aeromagnetic map evidence that they represent a single pluton.

Interestingly, no evidence for inheritance is recorded in the zircon population and the whole-rock, $\mathrm{Rb}-\mathrm{Sr}$, errorchron age of $1821 \pm 143 \mathrm{Ma}$ is within error of the $\mathrm{U}-\mathrm{Pb}$ zircon age. The initial ${ }^{87} \mathrm{Sr} /{ }^{86} \mathrm{Sr}$ ratio of the errorchron, recalculated for an intrusion age of $1887 \mathrm{Ma}$, is $0.7024 \pm 0.0008$, which is equal to the bulk Earth reservoir at that time. The low initial ratio implies that old Archaean crust did not contribute to the genesis of this pluton, and therefore suggests that the pluton was generated by partial melting of a source similar to the hosting Č́skejas Formation.

\section{Vuolgamašvuopmi granite pluton}

The Vuolgamašvuopmi granite pluton is hosted in the Masi Formation (Fig. 3). It is also well delineated on the aeromagnetic map by a prominent $11 \times 8 \mathrm{~km}$ anomaly, characterised by a homogeneous and moderately high magnetic signal (Fig. 2). The pluton is part of a set of plutons with granitic to trondhjemitic composition, called the Lávvoaivi plutons by Olsen \& Nilsen (1985). A 19-point, whole-rock, Rb-Sr errorchron, pooling samples from several of the Lávvoaivi plutons, including the Vuolgamašvuopmi pluton, returned an age of $1727 \pm$ $40 \mathrm{Ma}$ with an initial ${ }^{87} \mathrm{Sr} /{ }^{86} \mathrm{Sr}$ ratio of $c .0 .7037$.

Sample BBF108 (Fig. 11A) is a fresh, fine-grained, slightly inequigranular, biotite-muscovite foliated granite. It is from a homogeneous outcrop too small to establish clear field relationships. Zircon is prismatic and contains abundant intracrystalline fractures. Oscillatory zoning commonly grades from a CL luminescent core to a CL darker rim. Nine (out of a total of 13) U-Pb analyses performed in the core and rim in fracture-free volumes yield an upper intercept age of $1865 \pm 11 \mathrm{Ma}$. This age records the magmatic intrusion of the pluton. It is superceding the published $\mathrm{Rb}-\mathrm{Sr}$ errorchron age (Olsen \& Nilsen, 1985). Regression of all 13 analyses yields an equivalent (but statistically less favourable) upper intercept age of $1866 \pm 24 \mathrm{Ma}$.

\section{Palaeoproterozoic Ráiseatnu Complex}

\section{Geological characteristics}

The Ráiseatnu Complex is located in the western part of Finnmarksvidda (Figs. 1-3). On the aeromagnetic map, it is characterised by a short-wavelength, NNWSSE-trending, magnetic pattern showing isoclinal folds, very similar to the NNW-SSE-trending part of the Kautokeino Greenstone Belt (Fig. 2; Henderson et al., 2015). The contact between the Ráiseatnu Complex and the Kautokeino Greenstone Belt is a sharp, NNW-SSEtrending discontinuity, interpreted as a tectonic contact coeval with formation of the dominant NNW-SSE structural trend in the Kautokeino Greenstone Belt (Henderson et al., 2015). The Ráiseatnu Complex is made up of granitic to trondhjemitic gneiss interlayered with minor amphibolite, quartzite, calc-silicate and marble units (Figs. 2, 3, 7). The granitic gneiss is variably veined and heterogeneous. Some exposures appear as layered or migmatitic gneiss, with fine-grained granitic gneiss interlayered with coarser more leucocratic gneiss. Pegmatite bodies and mafic amphibolite layers are common. Some areas of the Ráiseatnu Complex are more homogeneous in composition.

The only published geochronology on the Ráiseatnu Complex is a zircon $\mathrm{U}-\mathrm{Pb}$ upper intercept age of 1824 +89 / -54 Ma for a homogeneous foliated granodioritic gneiss in Čierte (Fig. 3; Krill et al., 1985). This gneiss forms a c. $7 \mathrm{~km}$-wide dome in the northern part of the 
Ráiseatnu Complex (Fareth et al., 1977), which is prominent on the aeromagnetic map (Fig. 2). Krill et al. (1985) found evidence for inheritance in their sample, and consequently inferred the presence of older material in the Ráiseatnu Complex.

\section{$\mathrm{U}-\mathrm{Pb}$ results}

Sample BBF013 (Figs. 3, 11B) is a red granitic gneiss collected from a large pavement of granite gneiss near Njárgašlubbu in the northern part of the Ráiseatnu Complex. Nearby outcrops show several metre-thick layers of amphibolite, calc-silicate gneiss and impure marble, probably representing rafts of metasedimentary rock included in the protolith. The steep WNW-ESE-trending foliation at the locality is oblique to the general NNWSSE trend of the Ráiseatnu Complex. Zircon is prismatic and is characterised by low cathodoluminescence, and commonly contains a more luminescent core. Eighteen analyses were performed in 10 zircon crystals. Six nearconcordant analyses in four xenocrystic cores range from $2972 \pm 11$ to $2744 \pm 8 \mathrm{Ma}$. All other analyses on the prismatic zones with low cathodoluminescence, presumably metamict, are highly discordant. A subset of seven analyses define a discordia line with an upper intercept at 1841 $\pm 53 \mathrm{Ma}$ and a lower intercept at c. $439 \mathrm{Ma}$. The upper intercept age is taken as the age of crystallisation of the granite protolith to this gneiss.

Samples BBF101 and BBF102 (Figs. 3, 7, 11C, D) were collected c. $2 \mathrm{~km}$ from each other, near Jeageloaivi, in the central part of the Ráiseatnu Complex. Sample BBF102 is a homogeneous, poorly foliated, fine-grained trondhjemite. Sample BBF101 is a fine-grained, granitic gneiss from an outcrop containing leucosome or pegmatitic veins parallel to the main NNW-SSE foliation. Sample BBF102 has a simple oscillatory-zoned zircon population. Twelve LA-ICP-MS analyses of oscillatory-zoned zircon define a weighted average ${ }^{207} \mathrm{~Pb} /{ }^{206} \mathrm{~Pb}$ age of $1850 \pm 11$ $\mathrm{Ma}$, recording intrusion of the trondhjemite. Three additional analyses suggest some inheritance. Zircon in sample BBF101 is prismatic and oscillatory-zoned, and commonly shows a luminescent, also oscillatory-zoned, core. Nine SIMS analyses in the main growth zone of the zircons yield a weighted average ${ }^{207} \mathrm{~Pb} /{ }^{206} \mathrm{~Pb}$ age of $1828 \pm 5$ $\mathrm{Ma}$, interpreted as recording crystallisation of the granite. Analyses of inherited cores yield an earliest Palaeoproterozoic cluster at $2437 \pm 7 \mathrm{Ma}$ (5 analyses) and a single Archaean age of $2682 \pm 12$ Ma. Sample BBF101 thus represents a granite sheet intruded at $1828 \pm 5 \mathrm{Ma}$, probably marginally after emplacement of the nearby trondhjemite

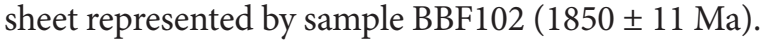

Sample BBF117 (Figs. 3, 11E) was collected from a large exposure at Beatnatmaras in the southern part of the Ráiseatnu Complex. The outcrop comprises a poorly foliated amphibolite, interlayered with minor heterogeneous granitic gneiss. The sample is a grey, fine-grained, biotite granite gneiss hosting minor, centimetre-thick, foliationparallel, coarse-grained leucocratic layers, possibly representing leucosomes. The zircons are prismatic. They show oscillatory zoning and commonly contain a large core characterised by bright cathodoluminescence and oscillatory zoning. Eleven SIMS U-Pb analyses of oscillatoryzoned material, in the core and rim of the zircons, define a discordia line with an upper intercept age of $1841 \pm 16$ $\mathrm{Ma}$ and a lower intercept at c. $436 \mathrm{Ma}$. Eight of these analyses are concordant and give an equivalent weighted average ${ }^{207} \mathrm{~Pb} /{ }^{206} \mathrm{~Pb}$ age of $1841 \pm 7 \mathrm{Ma}$, interpreted as recording intrusion of the granite layers. Seven of the analyses in cores range from $3100 \pm 17$ to $2716 \pm 24 \mathrm{Ma}$. Not all cores are inherited, but all inherited cores seem to be Archaean.

Sample BBF012 (Figs. 3, 11F) represents a small and isolated outcrop of weakly foliated, leucocratic trondhjemite near Holvinvárri. The rock is coarse grained, contains rare 2-6 cm-long biotite flakes and can be regarded as a pegmatitic trondhjemite. Relationships to the surrounding rocks cannot be observed. A priori, the pegmatitic trondhjemite was interpreted as a late intrusion. Zircon in this sample is generally metamict and characterised by very weak cathodoluminescence. Six SIMS analyses could be performed in zircon with some cathodoluminescence signal and some discernible oscillatory zoning. The analyses are discordant. They define a discordia line with an upper intercept age of $1868 \pm 13 \mathrm{Ma}$ and a lower intercept age of $c .441 \mathrm{Ma}$. The age of $1868 \pm 13 \mathrm{Ma}$ is consistent with the age of other granitoids in the Ráiseatnu Complex and dismiss the hypothesis that the pegmatitic trondhjemite is a late intrusive body.

\section{Interpretation}

The Ráiseatnu Complex is dominated by Palaeoproterozoic gneisses of granitic to trondhjemitic composition. The magmatic crystallisation of these granitoids is estimated at between $1868 \pm 13$ and $1828 \pm 5 \mathrm{Ma}$ (Figs. 5, $7,11)$. These granitoids are characterised by the common presence of rafts of metasedimentary rocks (quartzite and calc-silicate gneisses) and by a broad spectrum of xenocrystic zircons ranging in age from $3100 \pm 17$ to $2437 \pm 7 \mathrm{Ma}$ (Fig. 11). These features suggest that the granitoids were derived from partial melting of Palaeoproterozoic sedimentary rocks, deposited after c. 2437 $\mathrm{Ma}$ and containing a significant load of Archaean detrital zircons.

\section{Repparfjord Tectonic Window}

\section{Tectonostratigraphy}

In the new structural, stratigraphic and geochronological model presented in Torgersen et al. (2015a, b), the 

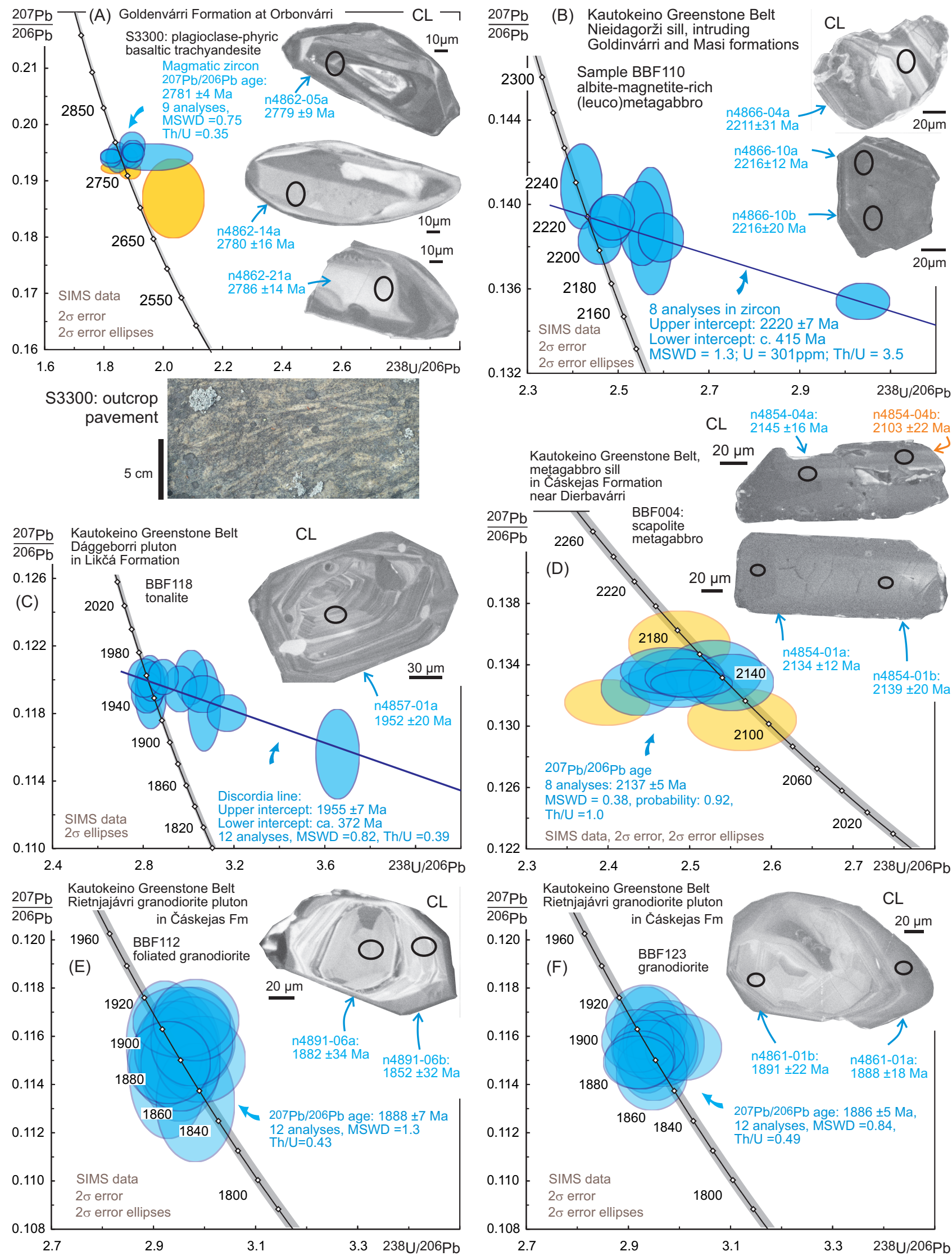

Figure 10. Zircon $U-P b$ data for samples of the Goldenvárri Formation and Kautokeino Greenstone Belt: Tera-Wasserburg concordia diagram and CL images for selected zircons with position of microanalyses. (A) Sample S3300, (B) BBF110, (C) BBF118, (D) BBF004, (E) BBF112, (F) BBF123. Same colour coding as in Fig. 8. 
Saltvatnet Group is interpreted as the stratigraphically lowest exposed unit of the sedimentary-volcanic succession in the Repparfjord Tectonic Window (Figs. 1, 4, 5). It occupies the core of a NE-SW-trending open anticline (Ulveryggen anticline) and consists of arkosic sandstone, conglomerate and minor dolostone. It has an unknown age and an unknown basement. On the northwestern flank of the anticline, the Saltvatnet Group is overlain by the Nussir Group, dominated by mafic metavolcanic rocks, and the Porsa Group dominated by metasedimentary rocks. On the southeastern flank, the Saltvatnet Group is overlain by the mafic volcanic Holmvatnet Group. The southeasternmost unit in the window is the clastic sedimentary Doggejohka Formation (Fig. 4). Its stratigraphic position is not well established. It could possibly be correlated with the Saltvatnet Group (Ulveryggen Formation) or, more probably, it may overlie the Holmvatnet Group. The sedimentary-volcanic succession of the Repparfjord Tectonic Window is intruded by two plutonic suites, the felsic Kvitfjellet suite and the mafic-ultramafic Rødfjellet (Raudfjell) suite (Nilsson \& Juve, 1979; Pharaoh et al., 1983).

The timing of deposition of the Nussir Group is defined by two dates: (1) A zircon population in a fine-grained layer, interpreted as a crystal-lithic tuff horizon, provides a maximum deposition age of $2073+23$ / - 12 Ma (Perelló et al., 2015) for the lower part of the group; (2) A Re-Os isochron age of $2069 \pm 14$ Ma from pyrite and chalcopyrite in mineralised veins (Porsa vein system) provides an overlapping minimum deposition age (Torgersen et al., 2015b).

The succession is affected by Svecokarelian greenschist to epidote-amphibolite facies metamorphism and deformation. Kilometre-scale, upright, NE-SW-trending folds indicate overall NW-SE shortening (Pharaoh et al., 1983; Torgersen et al., 2015a). Amphibole from metabasalt of the Holmvatnet Group yields an average $\mathrm{K}-\mathrm{Ar}$ age of $c$. $1842 \mathrm{Ma}$ (8 analyses in 3 samples), possibly recording regional cooling after the Svecokarelian orogeny (Pharaoh et al., 1982). Molybdenite collected in $\mathrm{Cu}$-mineralised dolomitic siltstone in the Saltvatnet Group yields younger Re-Os model ages of $1761 \pm 8$ and $1768 \pm 7 \mathrm{Ma}$ (Perelló et al., 2015), probably recording metamorphic crystallisation or recrystallisation of the sulphide assemblage.

\section{$\mathrm{U}-\mathrm{Pb}$ results}

We performed a preliminary $\mathrm{U}-\mathrm{Pb}$ geochronological survey on the Kvitfjellet and Rødfjellet suites in the southeastern part of the Repparfjord window. No zircon could be separated from trondhjemite of the Kvitfjellet suite. The Rødfjellet suite consists of numerous mafic to ultramafic bodies showing a general NE-SW elongation parallel to the regional structural trend. Some of them are clearly layered intrusions. The mineral assemblage reflects greenschist to lower amphibolite facies metamorphism, similar to that in the hosting metabasalt. We sampled a coarse metagabbro body hosted in the Doggejohka formation. The motivation to collect this sample was to test a correlation with the $2220 \pm 7$ Ma Nieidagorži sill in the Masi Formation (Fig. 10B) and therefore a correlation between the hosting Doggejohka and Masi formations.

The gabbro body in the Doggejohka formation is less than $100 \mathrm{~m}$ wide and elongated in a NE-SW trend, parallel to the generally well-bedded host quartzite. The gabbro is coarse grained, equigranular and massive and is composed mainly of medium-grained green hornblende and coarse-grained biotite that clearly overgrows the latter (Fig. 12F). The rock contains epidote and plagioclase and trace amounts of calcite and titanite. Ghosts of euhedral pyroxene and plagioclase laths are seen, but the original ophitic texture is entirely overprinted by metamorphism.

Sample ETO149 contains a few, large (c. $200 \mu \mathrm{m})$, prismatic zircon crystals with magmatic habit (Fig. 12A). Zircon is mostly radiation damaged, and transformed into metamict material with visible porosity on backscattered electron images and a weak cathodoluminescence signal. Eleven $\mathrm{U}-\mathrm{Pb}$ analyses were performed in six portions of crystals characterised by significant luminescence. Three of these analyses ( $U<200 \mathrm{ppm}$ ) are concordant, and define a weighted average ${ }^{207} \mathrm{~Pb} /{ }^{206} \mathrm{~Pb}$ age of $1903 \pm 18 \mathrm{Ma}$ (Fig. 12B). The eight remaining analyses correspond to discordant, high- $U$ ( $U>500$ ppm), metamict zircon. All eleven analyses, considered together, define a scattered discordia line (MSWD $=3.3$ ), with upper and lower intercepts at $1905 \pm 40 \mathrm{Ma}$ and $431 \pm 20 \mathrm{Ma}$. The age of $1903 \pm 18 \mathrm{Ma}$ is regarded as the best estimate for the magmatic crystallisation of the gabbro and by inference for emplacement of the Rødfjellet suite. The age of $1903 \pm 18$ Ma for the Rødfjellet suite places a minimum boundary for deposition of the hosting quartzite of the Doggejohka Formation and a maximum boundary for Svecokarelian metamorphism in the Repparfjord Tectonic Window.

\section{${ }^{40} \mathrm{Ar}-{ }^{39} \mathrm{Ar}$ results}

Results of ${ }^{40} \mathrm{Ar}-{ }^{39} \mathrm{Ar}$ analysis of biotite separated from ETO149 are reported in Fig. 12C-E. Apparent ages are concordant over most of the first $65 \%$ of released cumulative ${ }^{39} \mathrm{Ar}$, with a slight decline in apparent ages in the later steps. The four concordant steps (Fig. 12E; steps $3-6)$ yield a weighted mean plateau age of $1743 \pm 4 \mathrm{Ma}$.

Geological interpretation of biotite ${ }^{40} \mathrm{Ar}-{ }^{39} \mathrm{Ar}$ geochronological data carries significant uncertainty (Villa, 2016). The plateau age of $1743 \pm 4 \mathrm{Ma}$ either records metamorphic crystallisation of the biotite overgrowing hornblende, or records blocking of Ar diffusion in biotite, 
which means that it corresponds to a phase of cooling during regional unroofing. In this perspective, the biotite ${ }^{40} \mathrm{Ar}-{ }^{39} \mathrm{Ar}$ age is logically younger than amphibole $\mathrm{K}-\mathrm{Ar}$ ages of c. $1842 \mathrm{Ma}$ (Pharaoh et al., 1982), and marginally younger than the molybdenite Re-Os model ages of 1761 \pm 8 and $1768 \pm 7$ Ma (Perelló et al., 2015).

\section{Discussion}

\section{Archaean Jergul Complex: part of the Karelian Craton}

Gneissic and non-gneissic, tonalite-trondhjemitegranodiorite-granite rocks in the Jergul Complex range in age from $2975 \pm 10$ to $2776 \pm 6 \mathrm{Ma}$, with clear evidence for internal recycling in this time interval (Figs. 3, $5,8)$. The Goldenvárri Formation is an Archaean greenstone (Fig. 10A) associated with the Jergul Complex. Existing geochronological data probably mean that the entire anticlinorium structure between the Kautokeino and Karasjok Greenstone belts is made of Archaean crust (Fig. 1). The Jergul Complex is therefore regarded as a typical low heat-flow, Archaean, lithospheric block belonging to the Karelian Craton (Fig. 1). This conclusion was already implicit in the compilation maps of Sigmond et al. (1984), Siedlecka et al. (1985) and Koistinen et al. (2001), but is substantiated with these new results.

With an age of $2975 \pm 10 \mathrm{Ma}$, sample BBF039 from the Vuottašjávri borehole (Fig. 8A) is the oldest orthogneiss dated so far in Norway (Levchenkov et al., 1993; Bergh et al., 2007). Older tonalite-trondhjemite orthogneisses are, however, known from other parts of the Karelian Craton, including the c. $3500 \mathrm{Ma}$ orthogneisses at Pudasjärvi in Finland (Fig. 1; Mutanen \& Huhma, 2003; Lauri et al., 2011).

Relations between the Karelian and Norrbotten cratons are not established, as no geochronological data on Archaean rocks from the Norrbotten Craton have yet been published (Bergman et al., 2001; Martinsson et al., 2016). Whether these cratons were part of a single craton in the Archaean, or formed on different plates is not known. Work in progress indicates that the northeastern part of the Norrbotten Craton hosts orthogneisses with an age of c. $3215 \mathrm{Ma}$, older than the ones dated in the Jergul Complex (Lauri \& Lepistö, 2014; Lauri et al., 2016)

\section{Masi Formation: part of the Jatulian system}

The minimum age of $2220 \pm 7 \mathrm{Ma}$ for the deposition of the quartzite of the Masi Formation provided by the Nieidagorži sill (Fig. 10B) links the Masi quartzite to the classical Palaeoproterozoic Jatulian system of sedimentary and volcanic rocks (Fig. 6). The Jatulian system is bounded by a lower unconformity surface, either covering earliest Palaeoproterozoic supracrustal rocks (of the Sumian and Sariolian systems: 2505-2300 Ma; Fig. 6) or an Archaean basement (commonly showing evidence for subaerial alteration; Hanski \& Melezhik, 2013; Melezhik \& Hanski, 2013). In a regional context, Jatulian sedimentary rocks represent a transgressive sedimentation phase with conglomerate, quartz arenite and arenite sediments, reflecting either thermal subsidence of the Archaean craton or incipient rifting. The Masi Formation (Fig. 1) can be broadly correlated with the Sodankylä Group quartzites in the Central Lapland Greenstone Belt in Finland (Kittilä), the Kivalo Group quartzites in the Peräpohja Schist Belt in Finland (Perttunen \& Vaasjoki, 2001), and the Vanna Group covering the West Troms Basement Complex in Norway (Vannøya; Bergh et al., 2010). It possibly correlates with the Tjärro quartzite group covering the Norrbotten Craton in Sweden (Bergman et al., 2001). Speculatively, the Saltvatnet Group at the base of Repparfjord Tectonic Window succession (Fig. 4) could also represent a Jatulian sedimentary unit (Fig. 5; Torgersen et al., 2015a). In contrast, in the Alta-Kvænangen Tectonic Window, there is no known candidate to correlate with the Masi Formation (Fig. 5).

The unconformable contact of the Masi Formation onto the Archaean Goldenvárri Formation indicates that rocks of the Sumian and Sariolian systems (2505-2300 Ma; Fig. 6) are missing in Finnmarksvidda. More specifically, rocks correlated with the Salla Group and Onkamo Group (now Kuusamo Group) of the Central Lapland Greenstone Belt (Fig. 1), which are overwhelmingly composed of volcanic rocks extruded at around 2460-2440 $\mathrm{Ma}$, have no correlatives at the base of the Kautokeino Greenstone Belt (Manninen \& Huhma, 2001; Manninen et al., 2001; Räsänen \& Huhma, 2001; Hanski \& Huhma, 2005; Lauri et al., 2012b).

\section{Haaskalehto-type mafic sills in Masi Formation quartzite}

The age of $2220 \pm 7 \mathrm{Ma}$ for the intrusion of the Nieidagorži sill in the Masi Formation constrains this sill to an event of mafic magmatism occurring throughout the northeastern part of Fennoscandia between $c$. 2230 and $2200 \mathrm{Ma}$ (Fig. 6), and referred to as albite diabases, gabbro-wehrlite association (Hanski, 1986) or Haaskalehto-type intrusions (Rastas et al., 2001; Hanski et al., 2010). This magmatic event is coeval with the Nipissing diabases in the Superior Province in Laurentia (Corfu \& Andrews, 1986). It is characterised by diagnostic properties, summarised in Hanski (1986), Hanski \& Huhma (2005) and Hanski et al. (2010), and consistent with observations made on the Nieidagorži sill. The intrusions are typically sills, intruded in Jatulian sedimentary rocks and their nearby Archaean basement. The sills are several hundred metresin thickness, highly differentiated and usually comprise, from bottom up, the 
following cumulus mineral assemblages: olivine-clinopyroxene, clinopyroxene, clinopyroxene-magnetite, and plagioclase-clinopyroxene-magnetite. The magmatic plagioclase is generally transformed into albite. The magnetite cumulates are the reason for the prominent magnetic anomaly associated with most of these sills. This magmatic event is exemplified by the Haaskalehto intrusion $(2211 \pm 6 \mathrm{Ma})$ in the Central Lapland Greenstone Belt intruding the Jatulian Sodankylä Group (near Kittilä; Figs. 1, 5; Rastas et al., 2001; Hanski et al., 2010). It also includes the $c .100 \mathrm{~km}$-long Runkausvaara mafic sill $(2209 \pm 10 \mathrm{Ma})$ in the Kivalo Group of the Peräpohja Schist Belt in Finland (Huhma et al., 1990; Perttunen \& Vaasjoki, 2001). In Norway, a diorite sill, dated at $2221 \pm$ $3 \mathrm{Ma}$, is reported in the Vanna Group in the West Troms Basement Complex (Bergh et al., 2010). The Haaskalehto-type mafic sills, collected at the base of several greenstone belts up to $600 \mathrm{~km}$ apart, show a very consistent initial $\varepsilon_{\mathrm{Nd}}$ value of $+0.7 \pm 1.6$ (45 analyses $\pm 2 \sigma$; Fig. 6; Huhma et al., 1990; Hanski et al., 2010).

\section{Čáskejas Formation greenstone: the $2140 \mathrm{Ma}$ magmatic province}

The Čáskejas and Likčá formations form together the main unit of mafic volcanism and plutonism in the Kautokeino Greenstone Belt (Figs. 3, 9). The age of this magmatism is now best estimated by the age of $2137 \pm$ $5 \mathrm{Ma}$ for the probably synvolcanic Dierbavárri gabbro in the Čáskejas Formation (Fig. 10D). The mafic metavolcanic rocks of the Čáskejas Formation are characterised by a tholeiitic signature, with weak LREE enrichment (Fig. 9), and an initial $\varepsilon_{\mathrm{Nd}}$ value of $+2.2 \pm 1.7$ (Fig. 6). This $\varepsilon_{\mathrm{Nd}}$ value is calculated at $2137 \mathrm{Ma}$ from the five wholerock analyses of metabasalt, metatuffite and metadolerite by Krill et al. (1985). This mildly depleted $\varepsilon_{\mathrm{Nd}}$ value is situated in the middle of the evolution trend outlined in Fig. 6 for mafic magmatism in the Fennoscandian Shield.

Extrapolation of the structural trend in Finnmarksvidda towards the north using the aeromagnetic data suggests that the sedimentary-volcanic succession of the Kautokeino Greenstone Belt extends below the Caledonian nappes, to link with the one exposed in the AltaKvænangen Tectonic Window (Figs. 1, 2; Melezhik et al., 2015a; Nasuti et al., 2015a, b). The age of $2137 \pm 5$ $\mathrm{Ma}$ for the metagabbro sill in the Ćáskejas Formation (Fig. 10D) is identical within error to the age of $2146 \pm$ $5 \mathrm{Ma}$ for a gabbro sill in the Kvenvik Formation in the Alta-Kvænangen Tectonic Window (zircon $\mathrm{U}-\mathrm{Pb}$ data; Melezhik et al., 2015b). Both formations are dominated by low-grade mafic volcanic rocks, with similar geochemical signatures (Fig. 9). This substantiates at least a partial correlation betwen the Čáskejas and Kvenvik formations (Fig. 5; Bergh \& Torske, 1988; Olesen \& Sandstad, 1993; Melezhik et al., 2015a). However, the Kvenvik Formation contains three well identifiable dolostone intervals, which cannot be correlated with the ones observed in the Č́skejas or Likčá formations (Melezhik et al., 2015b).

With an age of c. $2137 \mathrm{Ma}$, the Ćáskejas Formation is coeval with a suite of mafic dykes intruding Archaean complexes of the Karelian Craton in Finland and Russia, dated between $2140 \pm 3$ and $2126 \pm 5 \mathrm{Ma}$ (zircon $\mathrm{U}-\mathrm{Pb}$ data; Stepanova et al., 2014). This dyke suite is not voluminous but it is extensive geographically. It exhibits a continental tholeiitic signature, generally lacking LREE enrichment (Fig. 9; Stepanova et al., 2014). It is characterised by an initial $\varepsilon_{\mathrm{Nd}}$ value of $+2.5 \pm 1.0$ defined by 23 analyses from 6 localities spread over more than 500 km (Fig. 6; Stepanova et al., 2014). Both the geochemical properties and $\mathrm{Nd}$ isotopic signature are remarkably uniform for this dyke suite, and also they are remarkably similar to the ones of the Čáskejas Formation $\left(\varepsilon_{\mathrm{Nd}}=+2.2\right.$; Figs. 6, 9). Available data therefore asuggest that these mafic magmatic rocks are part of one magmatic province at c. $2140 \mathrm{Ma}$ affecting Karelia, including both volcanic complexes and dyke swarms. Finally, it is worth mentioning that the Peräpohja Schist Belt in Finland (Fig. 1) includes a mafic sill, underlying the Jouttiaapa volcanic rocks (Huhma et al., 1990), dated at $2140 \pm 11 \mathrm{Ma}$ (zircon U-Pb data; Kyläkoski et al., 2012). Its occurrence suggests that more rocks of the same magmatic province probably exist over Fennoscandia, awaiting further documentation.

Contrary to traditional wisdom (Reitan, 1963; Pharaoh et al., 1983, 1987), new data presented in Perelló et al. (2015), Torgersen et al. (2015a, b) and this work (Fig. 12) dismiss a correlation between the sedimentaryvolcanic succession in the Repparfjord Tectonic Window and those in the Kautokeino Greenstone Belt and AltaKvænangen Tectonic Window (Figs. 1, 5). The age interval between $2073+23 /-12$ and $2069 \pm 14 \mathrm{Ma}$ for the deposition of the Nussir Group (Perello et al., 2015; Torgersen et al., 2015b) argues against (Fig. 5) a correlation between the dominantly mafic volcanic Nussir Group and the Čáskejas Formation (2137 \pm 5 Ma; Fig. 10D) or the Kvenvik Formation (2146 $\pm 5 \mathrm{Ma})$ (Melezhik et al., 2015b). In addition, no magmatism coeval with the Rødfjellet suite in the Repparfjord Tectonic Window is known as of today in the Kautokeino Greenstone Belt. The new age of $1903 \pm 18 \mathrm{Ma}$ for a metagabbro body of the Rødfjellet suite (Fig. 12) rules out a correlation with the $2220 \pm 7$ Ma Nieidagorži sill and does not support a correlation between the Doggejohka and Masi formations.

The lithostratigraphy of the Central Lapland Greenstone Belt in Finland is summarised in Lehtonen et al. (1998), Rastas et al. (2001) and Hanski \& Huhma (2005) (Figs. $1,5)$. The quartzite-rich Sodankylä Group, hosting Haaskalehto-type sills, exposed in the Kittilä area can be correlated with the Masi Formation. It is overlain by the Savukoski Group, which comprises phyllite, black schist, tuff, tuffite and basaltic volcanic rocks, overlain 
by subaqueous picrite and komatiite volcanic rocks. The Savukoski Group is not dissimilar to the Suoluvuopmi Formation in Kautokeino. However, a geochronological correlation cannot be established. A composite Sm$\mathrm{Nd}$ isochron in the komatiites-picrites of the Savukoski Group (Jeesiörova and Peuramaa volcanic rocks) yields an age of $2056 \pm 25 \mathrm{Ma}$ (Hanski et al., 2001a), in agreement with a minimum $\mathrm{U}-\mathrm{Pb}$ age of $2046 \pm 9 \mathrm{Ma}$ for an intrusive sill (Rastas et al., 2001). The Savukoski Group is overlain, along a tectonic contact, by the Kittilä Group consisting of mafic volcanic rocks. Minor felsic volcanic rocks associated with the Kittilä Group yield a pooled zircon $\mathrm{U}-\mathrm{Pb}$ age of $2015 \pm 3 \mathrm{Ma}$, supporting a Sm-Nd isochron age of $1990 \pm 35 \mathrm{Ma}$ for tholeiitic basalts (Vesmajärvi Formation; Rastas et al., 2001; Hanski \& Huhma, 2005). Existing data therefore indicate that the voluminous mafic magmatism exposed in the Kittilä Group $(2015 \pm 3 \mathrm{Ma})$ is much younger than the Ćáskejas Formation $(2137 \pm 5 \mathrm{Ma})$ and that these two units do not correlate (Fig. 5). The Savukoski Group is broadly coeval with the Nussir Group in the Repparfjord Tectonic Window, although a direct correlation is yet to be demonstrated.

\section{Svecokarelian plutons}

Intrusion of the large Rietnjajávri pluton in the Čáskejas Formation (1888 $\pm 7 \mathrm{Ma}$; Fig. 10E, F) and Vuolgamašvuopmi pluton in the Masi Formation (1865 $\pm 11 \mathrm{Ma}$; Fig. 11A) straddle the time interval between $c$. 1890 and $1860 \mathrm{Ma}$ of synorogenic granitoid magmatism associated with the Svecokarelian orogeny, documented in southern, northern and central Finland (Central Finland granitoid complex; Lahtinen et al., 2005; Nironen, 2005; Korja et al., 2006). More specifically, the age and metaluminous character of the Rietnjajávri pluton links this pluton to the Haaparanta (Haparanda) suite in northern Sweden and Finland. The Haaparanta suite typically consists of metaluminous monzodiorite to granodiorite plutons (Bergman et al., 2001; Väänänen \& Lehtonen, 2001; Nironen, 2005). It notably includes the large (c. $300 \mathrm{~km}^{2}$ ) Kallo composite granitoid pluton in the Kittilä area (Fig. 1), dated at $1882 \pm 1 \mathrm{Ma}$ (Väänänen \& Lehtonen, 2001). A peraluminous character disqualifies the Vuolgamašvuopmi pluton as a member of the Haaparanta suite.

\section{Palaeoproterozoic granitoid of the Ráiseatnu Complex}

The new geochronological data on granitoids of the Ráiseatnu Complex yield surprisingly young intrusion ages ranging from $1868 \pm 13$ to $1828 \pm 5 \mathrm{Ma}$ (Figs. 5, 7, 11). The common rafts of metasedimentary rocks and the broad distribution of xenocrystic zircons between 3100 \pm 17 and $2437 \pm 7 \mathrm{Ma}$ (Fig. 11) imply that the granitoids were generated by partial melting of a Palaeoproterozoic basement rich in sedimentary rocks. This leads to two possible interpretations: (1) The Ráiseatnu Complex represents reworked/ melted supracrustal rocks related to the Kautokeino Greenstone Belt, more precisely metasedimentary rocks correlating with the Masi and Suoluvuopmi formations. This is realistic as metamorphic grade increases westwards in the Ćáskejas Formation and possibly reached muscovite and biotite incongruent melting conditions in the Ráiseatnu Complex (quartzite s.s. is not a fertile lithology and survived as rafts). This interpretation was already suggested by Olesen \& Sandstad (1993). (2) The Ráiseatnu Complex represents a reworked Svecofennian sedimentary-volcanic succession deposited in the $c$. 1960-1850 Ma time interval, akin to the widespread basins exposed southwestwards in Finland and Sweden in the Svecokarelian orogen (Lahtinen et al., 2005; Korja et al., 2006; Högdahl et al., 2008). This basin is possibly far travelled and unrelated to the Kautokeino Greenstone Belt. Isotopic data and detrital zircon data in sediment rafts are necessary to settle this discussion. Irrespective of the preferred interpretation, Henderson et al. (2015) concluded that the contact between the NNW-SSE Kautokeino Greenstone Belt and the Ráiseatnu Complex did accommodate very significant lateral displacement, which complicates simple correlations across this high-strain zone.

\section{Svecokarelian deformation and metamorphism}

At the scale of the Svecokarelian orogen, the peak of Svecokarelian terrane accretion took place at around 1930$1880 \mathrm{Ma}$. Accretion was followed by several orogenic and magmatic phases between c. 1890 and $1770 \mathrm{Ma}$ (Lahtinen et al., 2005; Nironen, 2005; Korja et al., 2006).

In the Repparfjord Tectonic Window, Pharaoh et al. (1983) interpreted the NE-SW-trending Rødfjellet mafic suite as a synorogenic Svecokarelian suite, probably associated with roughly NW-SE compression. The age of $1903 \pm 18 \mathrm{Ma}$ (Fig. 12) validates this interpretation and may in part constrain the age of the NW-SE compressional phase. Additional work and data are, however, required to evaluate the exact tectonic and geodynamic significance of the Rødfjellet suite. Overall NWSE shortening has also been inferred for the formation of the $\mathrm{Cu}$-mineralised carbonate veins in the Repparfjord Tectonic Window at $2069 \pm 14 \mathrm{Ma}$ (Re-Os age; Figs. 4, 5 ; Torgersen et al., 2015b).

In Finnmarksvidda, interpretation of aeromagnetic data (Fig. 2) and field data led Henderson et al. (2015) to conclude on two main phases of Svecokarelian deformation. (1) The first phase corresponds to E-W or NW-SE compression, resulting in bivergent eastward and westward orthogonal thrusting. These structures are well preserved in the NE-SW-trending structural compartment of the Kautokeino Greenstone Belt (Fig. 2), as well as in the Repparfjord Tectonic Window. (2) The second 

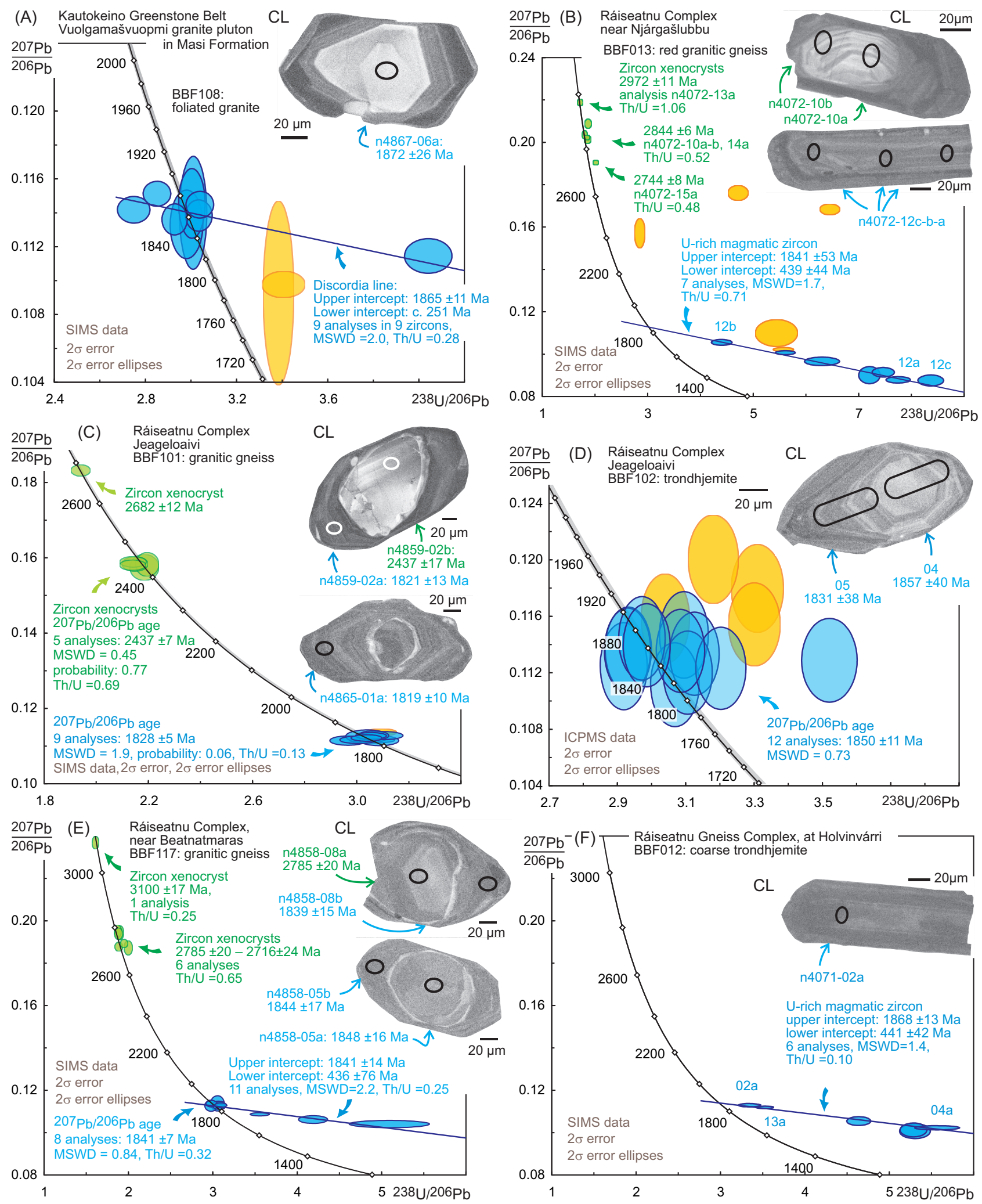

Figure 11. Zircon $\mathrm{U}-\mathrm{Pb}$ data for samples of the Vuolgamašvuopmi pluton and Ráiseatnu Complex: Tera-Wasserburg concordia diagram and CL images for selected zircons with position of microanalyses. (A) Sample BBF108, (B) BBF013, (C) BBF101, (D) BBF102, (E) BBF117, (F) BBF012. Same colour coding as in Fig. 8.

phase is a sinistral transpression, which resulted in the development of NNW-SSE-trending, dominantly sinistral shear zones, defining the prominent NNW-SSE structural compartment characterising the central and western parts of the Kautokeino Greenstone Belt and the Ráiseatnu Complex (Fig. 2). The steep NNW-SSEtrending tectonic zone between the Kautokeino Greenstone Belt and the Ráiseatnu Complex is one of those. 

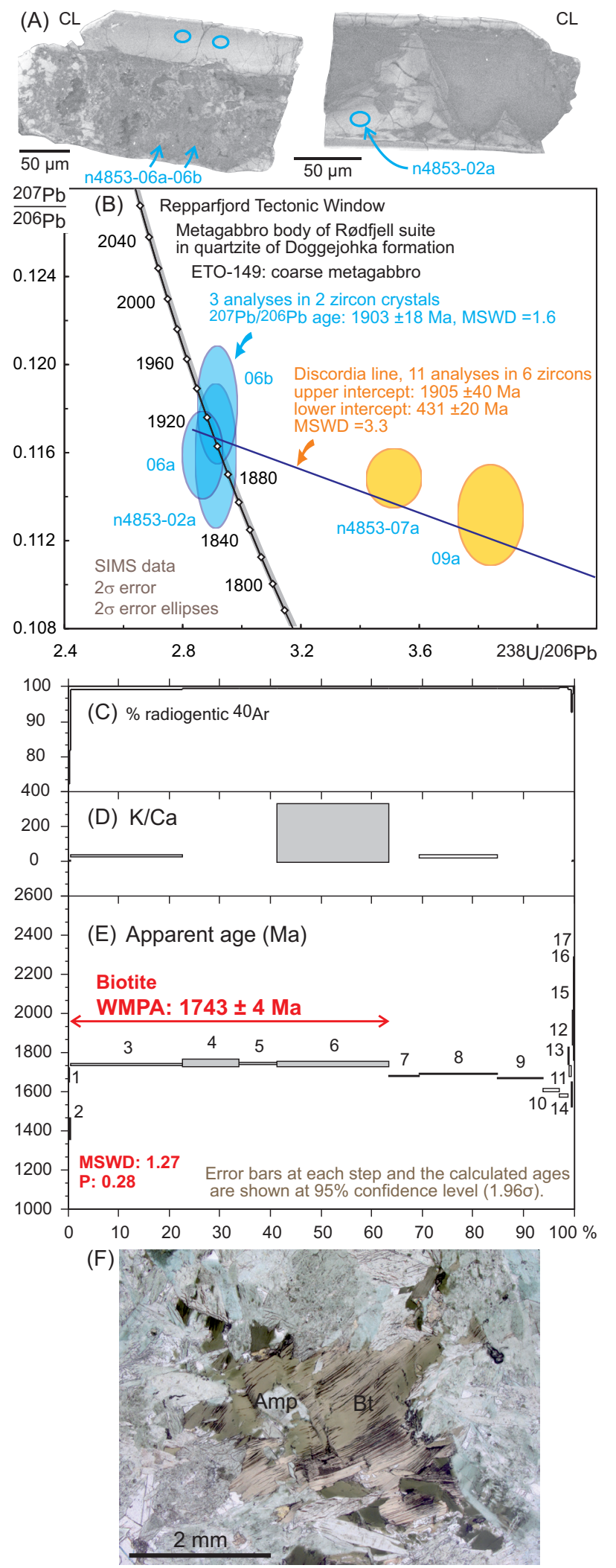

Figure 12. Zircon $\mathrm{U}-\mathrm{Pb}$ data and biotite ${ }^{40} \mathrm{Ar}-{ }^{39} \mathrm{Ar}$ data for the sample of metagabbro, ETO149, of the Rødfjellet suite in the Repparfjord Tectonic Window. (A), (B) Zircon $\mathrm{U}-\mathrm{Pb}$ data: $\mathrm{CL}$ images and concordia diagram (same colour coding as in Fig. 8). (C), (D), (E) Biotite ${ }^{40} \mathrm{Ar}-{ }^{39} \mathrm{Ar}$ data: \% radiogenic ${ }^{40} \mathrm{Ar}, \mathrm{K} / \mathrm{Ca}$ ratio (calculated from ${ }^{39} \mathrm{Ar}_{\mathrm{K}}{ }^{137} \mathrm{Ar} \mathrm{Ca}_{\mathrm{Ca}}$ ), and ${ }^{40} \mathrm{Ar}-{ }^{39} \mathrm{Ar}$ age spectrum. (F) Photomicrograph showing coarse-grained biotite partly overgrowing hornblende. WMPA - weighted mean plateau age.
It includes a component of westward thrusting of the Kautokeino Greenstone Belt on top of the Ráiseatnu Complex and a component of sinistral strike-slip shearing (Henderson et al., 2015).

The age and structural relationships of the Rietnjajávri and Vuolgamašvuopmi plutons relative to their host rock help to constrain the timing of deformation of the late transpression phase (Henderson et al., 2015). Both plutons are weakly foliated. The eastern boundary of both of them runs parallel to short-wavelength magnetic anomalies in their respective host rock (Fig. 2). As a first approximation, these contacts are conformable and the intrusion age of the plutons cannot be used to bracket deformation in these hosts. Contrastingly, the western boundary of both plutons is unambiguously truncated and reworked by two of the steeply-dipping, NNWSSE-trending shear zones, with a component of sinistral shear (Figs. 2, 3) (Henderson et al., 2015). Therefore, the intrusion age of $1865 \pm 11 \mathrm{Ma}$ (Fig. 11A) for the Vuolgamašvuopmi pluton, hosted in the Masi Formation, defines an upper age limit for deformation along the shear zone marking the eastern boundary of the NNW-SSE-trending structural compartment (Fig. 2). In the same way, the intrusion age of $1888 \pm 7 \mathrm{Ma}$ (Fig. $10 \mathrm{E})$ for the Rietnjajávri granodiorite pluton, hosted in the Čáskejas Formation, defines a similar upper age limit for shearing at the boundary between the Kautokeino Greenstone Belt and the Ráiseatnu Complex. Collectively, considering the Kautokeino Greenstone Belt and the Repparfjord Tectonic Window, the transition from the first phase of E-W to NW-SE compression to the second phase of sinsitral transpression along NNW-SSE shear zones is thus probably bracketed between $1903 \pm$ $18 \mathrm{Ma}$ and $1888 \pm 7 \mathrm{Ma}$.

Granitoids in the Ráiseatnu Complex point towards a major event of crustal melting between $1868 \pm 13$ and $1828 \pm 5 \mathrm{Ma}$ in the western part of Finnmarksvidda. The age of $1828 \pm 5 \mathrm{Ma}$ is derived from a veined granitic gneiss oriented parallel to the regional NNW-SSE structural trend. This result suggests that the penetrative isoclinal fold pattern observed on the aeromagnetic map in the Ráiseatnu Complex (Fig. 2) is coeval or younger than $1828 \pm 5 \mathrm{Ma}$, i.e., it is younger than in the Ćáskejas Formation. This is consistent with the upper age limit of $1888 \pm 7$ Ma provided by intrusion of the Rietnjajávri granodiorite pluton for shearing along the KautokeinoRáiseatnu boundary.

The biotite ${ }^{40} \mathrm{Ar}-{ }^{39} \mathrm{Ar}$ plateau age of $1743 \pm 4 \mathrm{Ma}$ in the eastern part of the Repparfjord Tectonic Window (Fig. $12 \mathrm{E})$ and the zircon overgrowth at $1765 \pm 10 \mathrm{Ma}$ in the Jergul Complex (Fig. 8B) represent evidence for a late Svecokarelian metamorphic event. Metamorphic homogenisation is also possibly recorded in the $\mathrm{Rb}-\mathrm{Sr}$ errorchron at $1727 \pm 40 \mathrm{Ma}$ for the Vuolgamašvuopmi granite pluton (Olsen \& Nilsen, 1985). The geotectonic significance of this younger metamorphism between 
1765 and $1740 \mathrm{Ma}$ is difficult to assess. It is shortly following and overlapping with an event of granite plutonism dated between 1790 and $1760 \mathrm{Ma}$. This magmatism is volumetrically minor but distributed widely over Fennoscandia, and called in different regions Nattanen-type or Matalavaara-type granites (Heilimo et al., 2009; Lauri et al., 2012a; Ranta et al., 2015).

\section{Bidjovagge Au-Cu deposit}

The Bidjovagge $\mathrm{Au}-\mathrm{Cu}$ deposit is located in the lower part of the Ćáskejas Formation some $3 \mathrm{~km}$ east of the boundary between the Kautokeino Greenstone Belt and the Ráiseatnu Complex (Figs. 2, 3). The deposit is specifically associated with albite-quartz rocks and graphite schist in a structurally complex NNW-SSE-trending structure (Sandstad, 1985; Bjørlykke et al., 1987; Nilsen \& Bjørlykke, 1991; Henderson et al., 2015). Mineralisation is largely related to the intersection of favourable lithologies with late, NNW-SSE-trending, strike-slip shear zones, associated with a probable sinistral shear sense (Nilsen \& Bjørlykke, 1991; Henderson et al., 2015). The NNW-SSE-trending shear zones controlling the mineralisation are thus subparallel to the shear system bounding the Kautokeino Greenstone Belt against the Ráiseatnu Complex.

The timing of mineralisation in the deposit is estimated by $\mathrm{U}-\mathrm{Pb}$ data from uraninite from a calcite vein hosted in a diabase body and from davidite (an oxide mineral of $\mathrm{Ti}-\mathrm{V}-\mathrm{Cr}-\mathrm{U}-\mathrm{REE}$ ) hosted in an albite-quartz rock. Although these $\mathrm{U}-\mathrm{Pb}$ data are highly discordant, they provide upper intercept ages of $1837 \pm 8$ and $1885 \pm 18$ Ma, respectively (Bjørlykke et al., 1990; Cumming et al., 1993). Davidite in the same sample set defines a 5 point Sm-Nd isochron with an overlapping age of $1886 \pm 88$ Ma (Bjørlykke et al., 1990). The correlation between radioactivity and $\mathrm{Au}$ concentration in the deposit links uraninite and davidite to the ore-forming process.

It is difficult to decide which one of the three age estimates $-1886 \pm 88,1885 \pm 18$ or $1837 \pm 8 \mathrm{Ma}-$ is the most indicative of the ore-forming process in Bidjovagge (discussion in Cumming et al., 1993). However, the three age estimates are younger than the age of the host greenstone at $2137 \pm 5 \mathrm{Ma}$ (Fig. 10D). Therefore, they strongly suggest that mineralisation took place after deposition of the succession, namely during the Svecokarelian orogeny involving folding, shearing, metasomatism and metamorphism (Bjørlykke et al., 1990; Nilsen \& Bjørlykke, 1991; Cumming et al., 1993). These age estimates overlap with the age of the Rietnjajávri pluton in the Ćáskejas Formation (1888 $\pm 7 \mathrm{Ma}$; Fig. 10E), which also defines an upper age limit for shearing along the Kautokeino Greenstone Belt-Ráiseatnu Complex boundary. They also overlap with the age of granite magmatism in the Ráiseatnu Complex (1868 \pm 13 to $1828 \pm 5$ Ma; Fig. 11). Therefore, genetic relationships between development of the Bidjovagge deposit and shearing along the NNWSSE shear system and/or granite genesis in the Ráiseatnu Complex are compatible with the geochronological data.

The $\varepsilon_{\mathrm{Nd}}$ value for davidite in the mineralisation (Bjørlykke et al., 1990) scatters between +2 and -5 if calculated at $2137 \mathrm{Ma}$ (Fig. 6) or -3 to -9 if calculated at 1860 Ma. These intervals are below the value of +2.2 for the host greenstone at $2137 \mathrm{Ma}$ (Fig. 6; or +1.5 calculated at $1860 \mathrm{Ma}$; Krill et al., 1985). This supports the idea that the deposit was generated after $2137 \mathrm{Ma}$ and includes a component characterised by less radiogenic $\mathrm{Nd}$ than the greenstone, i.e., with negative $\varepsilon_{\mathrm{Nd}}$ values and upper crustal isotopic signature.

\section{Geotectonic setting: episodic Palaeoproterozoic rifting}

The Palaeoproterozoic greenstone belts of Fennoscandia are traditionally interpreted as evidence for extension, continental rifting and possibly dispersal of one (or several) Archaean continent(s) between c. 2505 and $1930 \mathrm{Ma}$, while the Svecokarelian orogeny accommodated accretion of microcontinents and reassembly of Archaean blocks after 1930 Ma (e.g., Olesen \& Sandstad, 1993; Bogdanova et al., 2008; Lahtinen et al., 2008, 2009; Melezhik \& Hanski, 2013). In the Repparfjord Tectonic Window, Torgersen et al. (2015a) evoke a transient phase of compression and basin inversion already at $c$. $2070 \mathrm{Ma}$. Several phases of rifting associated with several pulses of mafic magmatism are recorded, each characterised by a distinct Nd isotopic signature (Fig. 6). Whether a complete Wilson-cycle took place in the Palaeoproterozoic between the Archaean continental blocks, involving development of oceanic basins, followed by oceanic closure during the Svecokarelian orogeny, remains a matter of speculation. In Finland, a handful of mafic-ultramafic complexes that formed between c. 2020 and $1950 \mathrm{Ma}$ are interpreted as possible ophiolites (Jormua, Outokumpu and Nuttio complexes) and testify to oceanic lithosphere (Peltonen, 2005; Lahtinen et al., 2008). In the timeline of Fig. 6, these correspond to the segment for which the basalt-producing mantle stabilises at around an $\varepsilon_{\mathrm{Nd}}$ value of +4 (i.e., after c. $2090 \mathrm{Ma}$ ).

The Kautokeino Greenstone Belt, Central Lapland Greenstone Belt and Ráiseatnu Complex are situated between the Karelian Craton in the east and the Norrbotten Craton in the west (Fig. 1). In a set of synthetic models, Lahtinen et al. (2005), Korja et al. (2006), and Lahtinen et al. $(2008,2009)$ unravelled the evolution between these two cratons by using geological evidence from Central Lapland. The new data presented in this paper, however, emphasise the lack of correlation between the Kittilä Group and Č́skejas Formation (Fig. 5), and therefore call for a more complicated model. In Fig. 13, we offer a preliminary lithospheric-scale model for rifting and reassembly along the Finnmarksvidda 

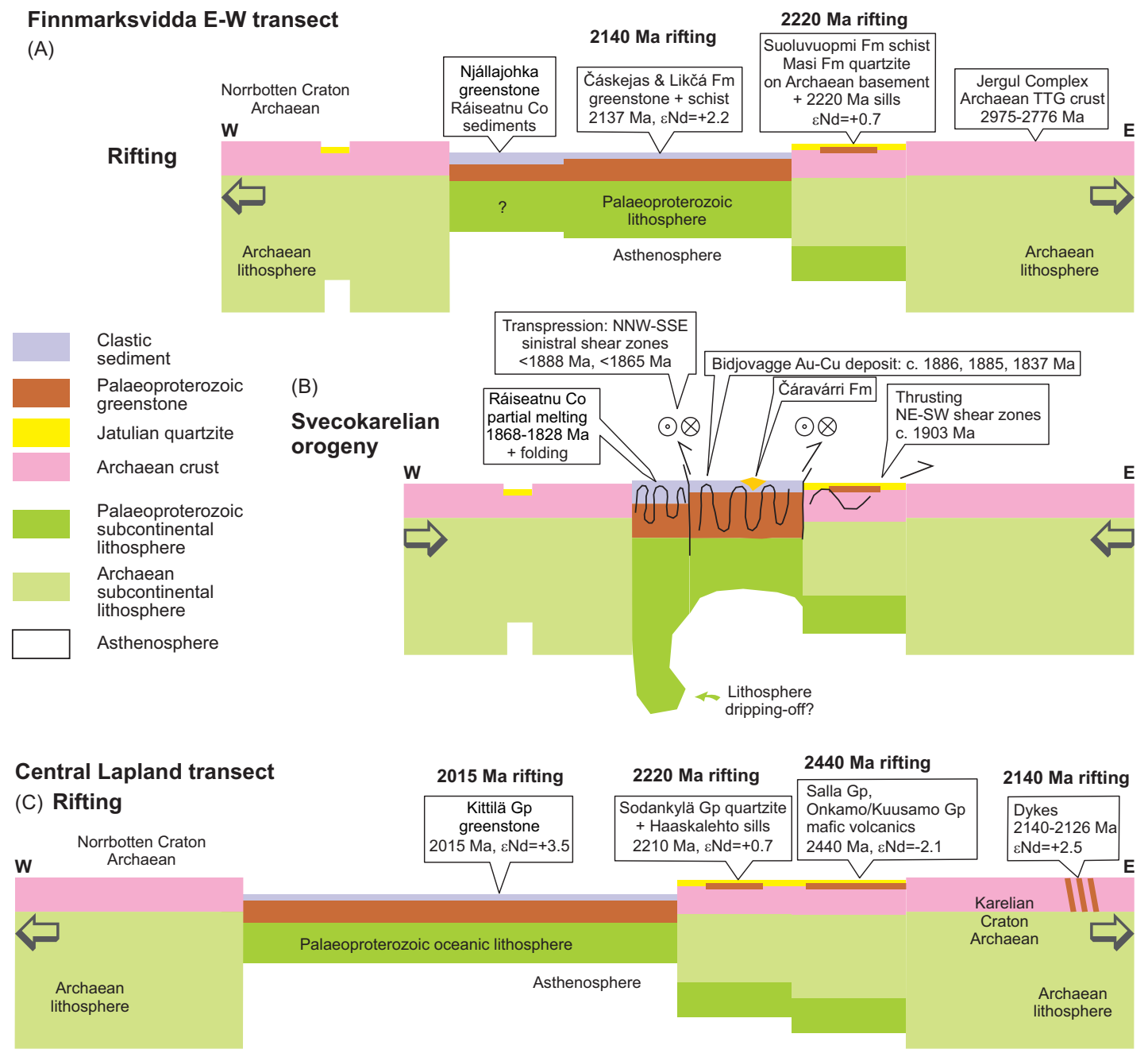

(D) Pre- to early-Svecokarelian

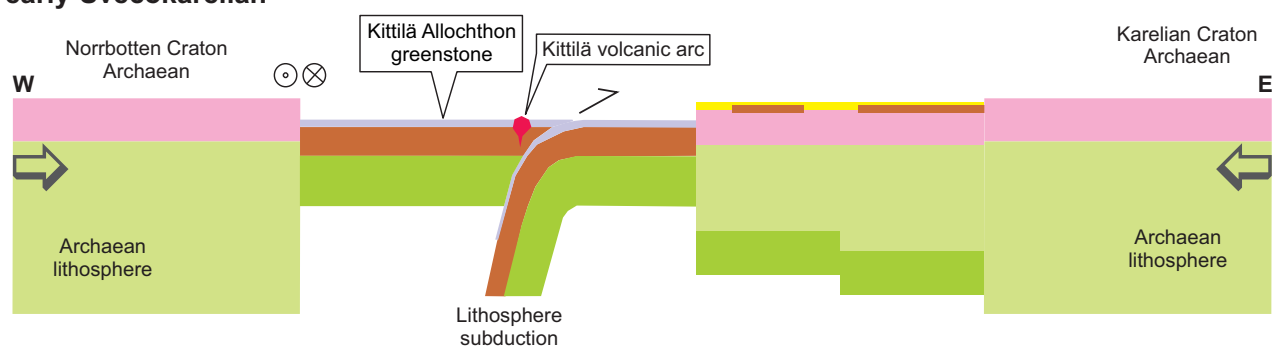

Figure 13. Lithospheric-scale geotectonic model for episodic rifting and reassembly along the Finnmarksvidda E-W transect, compared with the Kittilä transect (see Fig. 1 for position of the transects). Explanations provided in the text.

E-W transect, and highlight some differences between the Finnmarksvidda and Central Lapland transects.

In Finnmarksvidda, the first recorded phase of rifting took place at c. $2220 \mathrm{Ma}$ and corresponds to the deposition of quartzites of the Masi Formation and intrusion of Haaskalehto-type sills with an $\varepsilon_{\mathrm{Nd}}$ value of +0.7 \pm 1.6 (Figs. 5, 6, 13). Rifting took place in Archaean crust, as demonstrated by the basement-cover contact between the Goldenvárri and Masi formations. This suggests that the NE-SW-trending structural compartment of the Kautokeino Greenstone Belt (Fig. 2), exposing the Masi Formation, is constructed on Archaean lithosphere of Karelian affinity (Fig. 13). In the Central Lapland Greenstone Belt, an earlier phase of rifting is recorded at c. $2440 \mathrm{Ma}$, corresponding to the Salla Group and Onkamo/Kuusamo Group mafic volcanic rocks and associated sedimentary and plutonic rocks $\left(\varepsilon_{\mathrm{Nd}}=-2.1\right.$ at c. $2440 \mathrm{Ma}$; Manninen \& Huhma, 2001; Manninen et al., 2001; Räsänen \& Huhma, 2001; Hanski \& Huhma, 2005; Lauri et al., 2012b). The rifting phase at c. $2220 \mathrm{Ma}$ is well illustrated by quartzites of the Sodankylä Group intruded by Haaskalehto-type sills $\left(\varepsilon_{\mathrm{Nd}}=+0.7\right)$, also overlying an Archaean basement (Rastas et al., 2001; Hanski \& Huhma, 2005; Hanski et al., 2010). 
In Finnmarksvidda, the main phase of rifting took place at $2140 \mathrm{Ma}$ and is expressed by the greenstones of the Čáskejas and Likčá formations with an $\varepsilon_{\mathrm{Nd}}$ value of +2.2 \pm 1.7 (Figs. 6, 13). Preserved mafic volcanic rocks are interlayered with shale and minor dolostone, indicative of a marine environment (Sandstad, 1985; Siedlecka et al., 1985; Olesen \& Sandstad, 1993). However, they offer no positive geological evidence for an oceanic basin setting. This phase of rifting is coeval with dyke intrusion in the core of the Archaean Karelian Craton $\left(\varepsilon_{\mathrm{Nd}}=+2.5\right.$ \pm 1.0; Stepanova et al., 2014). The uniform isotopic signature of the $2140 \mathrm{Ma}$ magmatism is probably representative of the asthenospheric sources and rules out a large contribution of an Archaean lithospheric reservoir in the petrogenesis of this magmatism. The lack of evidence for Archaean basement or Archaean contamination for the Čáskejas and Likčá formations suggests that these greenstones are part of a juvenile Palaeoproterozoic crust with Palaeoproterozoic lithospheric mantle (Fig. 13).

Proterozoic lithospheric mantle has significantly different properties than Archaean lithospheric mantle (Poudjom Djomani et al., 2001); on average, it is less residual, thinner and weaker than the Archaean lithospheric mantle. During Svecokarelian (oblique) convergence, the Palaeoproterozoic lithosphere therefore accommodated most of the deformation between the Norrbotten and Karelian cratons, resulting in two deformation phases, including isoclinal folding and formation of the prominant NNW-SSE-trending shear zones after $c .1888$ Ma (Figs. 2, 13; Henderson et al., 2015). Intrinsically, the Palaeoproterozoic lithospheric mantle is heavier than the asthenosphere and therefore subductable. In Fig. 13, removal of the heavy, overthickened lithospheric mantle is represented by a dripping-off process (Gerya, 2014; rather than a subduction process, which is more typical for modern-style destruction of oceanic basins). The paleogeographic setting and ancestry of the Ráiseatnu Complex is difficult to assess with the existing data. In Fig. 13, it is tentatively represented as Proterozoic lithosphere with a significant sedimentary cover at the margin of the Norrbotten Craton. This sedimentary cover was affected by partial melting and granite production between $c .1868$ and $1828 \mathrm{Ma}$.

In the Central Lapland Greenstone Belt, the main phase of rifting is represented by the Kittilä Group greenstone at c. $2015 \mathrm{Ma}$ (Fig. 5). It is characterised by an average $\varepsilon_{\mathrm{Nd}}$ value of +3.5 , close to the value of the model depleted mantle (MORB-type; Fig. 6; note that some samples marginal to the belt give distinctly less radiogenic values). Lahtinen et al. (2005) and Korja et al. (2006) argued that the Kittilä Group contains evidence for oceanic basin magmatism, volcanic arc magmatism and oceanic basin closure (Nuttio serpentinites complex). The base of the Kittilä Group is tectonic, and their model proposes that the Kittilä Group is an allochthon, first attached to the Norrbotten Craton and then thrusted eastwards on top of the Karelian Craton during the Svecokarelian orogeny.
In Fig. 13, this model is considered to underscore the difference with the Finnmarksvidda transect. Consumption of the heavy lithospheric mantle is represented by a subduction process.

\section{Caledonian U-Pb lower intercept ages}

Zircon in several of the samples of the Kautokeino Greenstone Belt, Ráiseatnu Complex and Repparfjord Tectonic Window define discordia lines with a roughly Caledonian lower intercept age. The metagabbro of the Nieidagorži sill - sample BBF110 - gives a lower intercept age of $415 \pm 89 \mathrm{Ma}$ (Fig. 10B). Regression of eleven of the twelve SIMS analyses of this sample together with the five discordant ID-TIMS analyses of multigrain fractions of Krill et al. (1985) from the same locality confirms and improves the lower intercept. The pooled regression delivers a scattered discordia line with an upper intercept age of $2224 \pm 17 \mathrm{Ma}$ and a lower intercept age of $444 \pm 44$ Ma (16 analyses, MSWD = 10.6). The Dággeborri tonalite intruding the Likčá Formation - sample BBF118 yields a poor lower intercept of $372 \pm 140 \mathrm{Ma}$ (Fig. 10C). Three granitic to trondhjemitic samples from the Ráiseatnu Complex - BBF012, BBF013, BBF117 - give overlapping discordia lines with lower intercepts between 436 $\pm 76 \mathrm{Ma}$ and $439 \pm 44 \mathrm{Ma}$ (Fig. 11). Pooling these three samples together yields a robust discordia line with an upper intercept at $1846 \pm 13 \mathrm{Ma}$ and a lower intercept at $440 \pm 19 \mathrm{Ma}(25$ analyses, MSWD = 3.4). In the Repparfjord Tectonic Window, the metagabbro in the Doggejohka Formation - sample ETO149 - defines a lower intercept at $431 \pm 20 \mathrm{Ma}$ (MSWD = 3.3; Fig. 12B).

No large-scale, Caledonian, penetrative ductile deformation and metamorphism can be documented in the Palaeoproterozoic basement underlying the Caledonian nappes in Finnmark. In the western part of the Repparfjord Tectonic Window, brittle to ducile fault zones were activated during Caledonian convergence (Torgersen \& Viola, 2014; Torgersen et al., 2014). Potassium/argon data on synkinematic illite/muscovite in fault gouges constrain this localised deformation at $445 \pm 9 \mathrm{Ma}$ (Torgersen et al., 2014). In the same area, copper-mineralised veins were affected by localised mylonitisation, resulting in partial Caledonian resetting of the Re-Os system of pyrite and chalcopyrite (Torgersen et al., 2015b). Elsewhere in the basement, the effect of Caledonian orogeny is elusive. Noticeably, biotite ${ }^{40} \mathrm{Ar}-{ }^{39} \mathrm{Ar}$ data in the eastern part of the Repparfjord Tectonic Window sample ETO149 - do not provide any Caledonian signal (Fig. 12E), indicating a lack of Ar diffusion in biotite or mineral reaction involving biotite during the Caledonian orogeny.

Common to all samples characterised by Caledonian lower intercept ages is the presence of partly metamict zircon with a high $\mathrm{U}$ content $(\mathrm{U}>250 \mathrm{ppm}$, commonly $\mathrm{U}>1000 \mathrm{ppm})$. Evidence for metamictisation includes a 
weak CL signal, patchy zoning, fractures and microporosity (visible with the SEM). The effect of metamictisation on the $\mathrm{U}-\mathrm{Pb}$ systematics of zircon is well known (Mezger \& Krogstad, 1997). It includes components of radiogenic $\mathrm{Pb}$ loss, incorporation of non formula elements like $\mathrm{Ca}$ and common $\mathrm{Pb}$, and mobility of $\mathrm{U}$ at low temperature (Nasdala et al., 2010; Seydoux-Guillaume et al., 2015). The lower intercept ages in Finnmarksvidda are thus interpreted as a result of radiogenic $\mathrm{Pb}$ loss in zircon that did accummulate radiation damage between the Palaeoproterozoic and Phanerozoic. This episodic lead loss was triggered by Caledonian tectonic loading of the basement, but it does not imply metamorphism above $200^{\circ} \mathrm{C}$.

\section{Conclusions}

New geochronological data advance our understanding of the geological evolution of the Kautokeino Greenstone Belt and its neighbouring units in a Fennoscandian context. The main conclusions of this study are:

1) The Jergul Complex and Goldenvárri Formation, underlying the Kautokeino Greenstone Belt in the east, represent an Archaean tonalite-trondhjemitegranodiorite-granite gneiss and greenstone association, formed between $2975 \pm 10$ and $2776 \pm 6 \mathrm{Ma}$, and attached to the Karelian Craton.

2) The Masi Formation, unconformably overlying the Archaean basement at the base of the Kautokeino Greenstone Belt can be regarded as a typical Jatulian quartzite-rich formation. It hosts Haaskalehto-type mafic sills, one of which is dated at $2220 \pm 7 \mathrm{Ma}$.

3) The Čáskejas and Likčá formations represent the main accumulation of mafic volcanism and plutonism in the Kautokeino Greenstone Belt. The age of this magmatism is estimated at $2137 \pm 5 \mathrm{Ma}$. This magmatism is characterised by a tholeiitic signature, weak LREE enrichment, and an initial $\varepsilon_{\mathrm{Nd}}$ value of $+2.2 \pm$ 1.7. It is coeval with a suite of mafic dykes intruding the Archaean Karelian Craton in Finland and Russia, characterised by a remarkably similar geochemical and isotopic signature $\left(\varepsilon_{\mathrm{Nd}}=+2.5 \pm 1.0\right.$; Stepanova et al., 2014). These rocks can be regarded as part of one magmatic province at c. $2140 \mathrm{Ma}$. This uniformity of geochemical and isotopic signatures rules out contamination by Archaean crust as a major process for petrogenesis of this magmatism. The Čáskejas Formation can be correlated with the Kvenvik formation in the Alta-Kvænangen Tectonic Window (Melezhik et al., 2015a). It certainly does not correlate with the younger Nussir Group in the Repparford Tectonic Window (c. $2070 \mathrm{Ma}$; Torgersen et al., 2015a) or the Kittilä Group in the Central Lapland Greenstone Belt (c. 2015 Ma; Hanski \& Huhma, 2005).
4) The age of $1903 \pm 18 \mathrm{Ma}$ for the synorogenic Rødfjellet suite in the Repparfjord Tectonic Window is interpreted to date a phase of overall NW-SE Svecokarelian shortening. The ages of $1888 \pm 7$ and $1865 \pm 11$ $\mathrm{Ma}$ for two, large, granite-granodiorite plutons in the Kautokeino Greenstone Belt provide a maximum age for deformation along two, prominent, steep shear zones of the NNW-SSE-trending sinistral shear system recording Svecokarelian transpression. Formation of the Bidjovagge $\mathrm{Au}-\mathrm{Cu}$ deposit at $1886-1837 \mathrm{Ma}$ is also related to this NNW-SSE-trending shear system (Henderson et al., 2015).

6) The Ráiseatnu Complex is made up of granitic gneisses intruded between $1868 \pm 13$ and $1828 \pm 5 \mathrm{Ma}$, and is therefore younger than both the Kautokeino Greenstone Belt and the Jergul Complex. The granitic gneisses are rich in xenocrystic zircon ranging from $c$. 3100 to $2437 \mathrm{Ma}$, regarded as remelted Palaeoproterozoic metasedimentary rocks.

7) A synthetic lithospheric-scale geotectonic model is proposed for the Finnmarksvidda E-W transect involving two phases of rifting, at c. $2220 \mathrm{Ma}$ and 2140 $\mathrm{Ma}$, between the Karelian and Norrbotten Archaean cratons. Geological evidence suggests that the development of the Kautokeino Greenstone Belt took place in a pericontinental marine environment, rather than an oceanic environment. Rifting was followed by oblique convergence during the Svecokarelian orogeny.

Acknowledgements. This study is part of the project "Mineral Resources in Northern Norway" (MINN), hosted at the Geological Survey of Norway and funded by the Ministry of Trade, Industry and Fisheries of Norway. SIMS data were collected at the NORDSIM laboratory at the Swedish Museum of Natural History. This is NORDSIM publication \#457. Lev Ilyinsky and Kerstin Lindén contributed to collecting SIMS data. Whole-rock XRF and zircon LA-ICP-MS data were produced at the laboratory of the Geological Survey of Norway. Øyvind Skar contributed to collecting LA-ICP-MS data. Laura Lauri and Stephen Daly provided detailed and constructive reviews. David Roberts and Trond Slagstad are thanked, respectively, for a detailed reading and the editorial handling of the manuscript.

\section{References}

Amelin, Y.V. \& Semenov, V.S. 1996: Nd and Sr isotopic geochemistry of mafic layered intrusions in the eastern Baltic shield: implications for the evolution of Paleoproterozoic continental mafic magmas. Contributions to Mineralogy and Petrology 124, 255-272.

Andresen, A., Agyei-Dwarko, N.Y., Kristoffersen, M. \& Hanken, N.M. 2014: A Timanian foreland basin setting for the late Neoproterozoic-Early Palaeozoic cover sequences (Dividal Group) of northeastern Baltica. In Corfu, F., Gasser, D. \& Chew, D.M. (eds.): New perspectives on the Caledonides of Scandinavia and related areas, Geological Society of London Special Publications 390, pp. 157175. 
Balashov, Y.A., Bayanova, T.B. \& Mitrofanov, F.P. 1993: Isotope data on the age and genesis of layered basic-ultrabasic intrusions in the Kola Peninsula and northern Karelia, northeastern Baltic Shield. Precambrian Research 64, 197-205.

Bergh, S.G. \& Torske, T. 1988: Palaeovolcanology and tectonic setting of a Proterozoic metatholeiitic sequence near the Baltic Shield margin, northern Norway. Precambrian Research 39, 227-246.

Bergh, S.G., Kullerud, K., Corfu, F., Armitage, P.E.B., Davidsen, B., Johansen, H.W., Pettersen, T. \& Knudsen, S. 2007: Low-grade sedimentary rocks on Vanna, North Norway: a new occurrence of a Palaeoproterozoic (2.4-2.2 Ga) cover succession in northern Fennoscandia. Norwegian Journal of Geology 87, 301-318.

Bergh, S.G., Kullerud, K., Armitage, P.E.B., Zwaan, K.B., Corfu, F., Ravna, E.J.K. \& Myhre, P.I. 2010: Neoarchaean to Svecofennian tectono-magmatic evolution of the West Troms Basement Complex, North Norway. Norwegian Journal of Geology 90, 21-48.

Bergman, S., Kübler, L. \& Martinsson, O. 2001: Description of regional geological and geophysical maps of northern Norrbotten County (east of the Caledonian orogen). Geological Survey of Sweden Ba56, 110 pp. +3 maps.

Bjørlykke, A., Hagen, R. \& Soderholm, K. 1987: Bidjovagge coppergold deposit in Finnmark, Northern Norway. Economic Geology 82, 2059-2075.

Bjørlykke, A., Cumming, G.L. \& Krstic, D. 1990: New Isotopic data from davidites and sulfides in the bidjovagge gold-copper deposit, Finnmark, Northern Norway. Mineralogy and Petrology 43, 1-21.

Bogdanova, S., Bingen, B., Gorbatschev, R., Kheraskova, T., Kozlov, V., Puchkov, V. \& Volozh, Y. 2008: The East European Craton (Baltica) before and during the assembly of Rodinia. Precambrian Research $160,23-45$.

Boynton, W.V. 1984: Cosmochemistry of the rare earth elements; meteorite studies. In Henderson, P. (ed.): Rare earth element geochemistry, Elsevier Science B.V., Amsterdam, pp. 63-114.

Braathen, A. \& Davidsen, B. 2000: Structure and stratigraphy of the Palaeoproterozoic Karasjok Greenstone Belt, North Norway - regional implications. Norsk Geologisk Tidsskrift 80, 33-50.

Corfu, F. \& Andrews, A.J. 1986: A U-Pb age for mineralized Nipissing diabase, Gowganda, Ontario. Canadian Journal of Earth Sciences 23, 107-109.

Cumming, G.L., Krstic, D., Bjørlykke, A. \& Aasen, H. 1993: Further analyses of radiogenic minerals from the Bidjovagge gold-copper deposit, Finnmark, Northern Norway. Mineralogy and Petrology 49, 63-70.

Daly, J.S., Balagansky, V.V., Timmerman, M.J. \& Whitehouse, M.J. 2006: The Lapland-Kola orogen: Palaeoproterozoic collision and accretion of the northern Fennoscandian lithosphere. In Gee, D.G. \& Stephenson, R.A. (eds.): European Lithosphere Dynamics, Geological Society of London Memoirs 32, pp. 579-598.

DePaolo, D.J. 1981: A Neodymium and strontium isotopic study of the Mesozoic calk-alkaline granite batholiths of the Sierra Nevada and Peninsular Ranges, California. Journal of Geophysical Research 86, 10470-10488.

Eilu, P. 2012: Mineral deposits and metallogeny of Fennoscandia. Geological Survey of Finland Special Paper 53, 401 pp.

Fareth, E., Gjelsvik, T. \& Lindahl, I. 1977: Cier'te, beskrivelse til det berggrunnsgeologiske kart 1733 II, scale 1:50,000 (med fargetrykt kart). Norges geologiske undersøkelse Skrifter 331, 28 pp.

Føyn, S. 1967: Dividal-gruppen ("Hyolithus-sonen") i Finnmark og dens forhold til de eokambriske-kambriske formasjoner. Norges geologiske undersøkelse Bulletin 249, 84 pp.

Gerya, T. 2014: Precambrian geodynamics: Concepts and models. Gondwana Research 25, 442-463.

Hanski, E. 1986: The gabbro-wehrlite association in the eastern part of the Baltic Shield. In Friedrich, G.H., Genkin, A.D., Naldrett, A.J., Ridge, J.D., Sillitoe, R.H. \& Vokes, F.M. (eds.): Geology and metallogeny of copper deposits, Springer-Verlag, pp. 151-170.
Hanski, E.J. 1992: Petrology of the Pechenga ferropicrites and cogenetic, Ni-bearing gabbro-wehrlite intrusions, Kola Peninsula, Russia. Geological Survey of Finland Bulletin 367, 192 pp.

Hanski, E. 2001: History of stratigraphical research in northern Finland. In Vaasjoki, M. (ed.): Radiometric age determinations from Finnish Lapland and their bearing on the timing of Precambrian volcano-sedimentary sequences, Geological Survey of Finland Special Paper 33, pp. 15-44.

Hanski, E. \& Huhma, H. 2005: Central Lapland greenstone belt. In Lehtinen, M., Nurmi, P.A. \& Rämö, O.T. (eds.): Precambrian Geology of Finland. Key to the Evolution of the Fennoscandian Shield, Elsevier Science B.V., Amsterdam, pp. 139-193.

Hanski, E.J. \& Melezhik, V.A. 2013: Litho- and chronostratigraphy of the Palaeoproterozoic Karelian Formations (Chapter 3.2). In Melezhik, V.A., Prave, A.R., Fallick, A.E., Kump, L.R., Strauss, H., Lepland, A. \& Hanski, E.J. (eds.): Reading the archive of Earth's oxygenation; Volume 1: The Palaeoproterozoic of Fennoscandia as context for the Fennoscandian Arctic Russia - Drilling Early Earth Project, Springer-Verlag, pp. 39-111.

Hanski, E., Huhma, H., Rastas, P. \& Kamenetsky, V.S. 2001a: The Palaeoproterozoic komatiite-picrite association of Finnish Lapland. Journal of Petrology 42, 855-876.

Hanski, E., Walker, R.J., Huhma, H. \& Suominen, I. 2001b: The Os and $\mathrm{Nd}$ isotopic systematics of c. $2.44 \mathrm{Ga}$ Akanvaara and Koitelainen mafic layered intrusions in northern Finland. Precambrian Research 109, 73-102.

Hanski, E., Huhma, H. \& Vuollo, J. 2010: SIMS zircon ages and Nd isotope systematics of the $2.2 \mathrm{Ga}$ mafic intrusions in northern and eastern Finland. Bulletin of the Geological Society of Finland 82, 31-62.

Heilimo, E., Halla, J., Lauri, L.S., Rämö, O.T., Huhma, H. \& Front, K. 2009: The Paleoproterozoic Nattanen-type granites in northern Finland and vicinity - a postcollisional oxidized A-type suite. Bulletin of the Geological Society of Finland 81,7-36.

Henderson, I.H.C., Viola, G. \& Nasuti, A. 2015: A new tectonic model for the Palaeoproterozoic Kautokeino Greenstone Belt, northern Norway, based on high-resolution airborne magnetic data and field structural analysis and implications for mineral potential. Norwegian Journal of Geology 95, 339-363. http://dx.doi. org/10.17850/njg95-3-05.

Henriksen, H. 1983: Komatiitic chlorite-amphibole rocks and mafic metavolcanics from the Karasjok greenstone belt, Finnmark, northern Norway: a preliminary report. Norges geologiske undersøkelse Bulletin 382, 17-43.

Högdahl, K., Sjöström, H., Andersson, U.B. \& Ahl, M. 2008: Continental margin magmatism and migmatisation in the westcentral Fennoscandian Shield. Lithos 102, 435-459.

Holmsen, P., Padget, P. \& Pehkonen, E. 1957: The Precambrian geology of Vest-Finnmark, northern Norway. Norges geologiske undersøkelse Bulletin 201, 106 pp.

Hölttä, P., Balagansky, V., Garde, A.A., Mertanen, S., Peltonen, P., Slabunov, A., Sorjonen-Ward, P. \& Whitehouse, M. 2008: Archean of Greenland and Fennoscandia. Episodes 31, 13-19.

Hoskin, P.W.O. \& Black, L.P. 2000: Metamorphic zircon formation by solid-state recrystallization of protolith igneous zircon. Journal of Metamorphic Geology 18, 423-439.

Huhma, H., Cliff, R.A., Perttunen, V. \& Sakko, M. 1990: Sm-Nd and $\mathrm{Pb}$ isotopic study of mafic rocks associated with early Proterozoic continental rifting: the Peröpohja schist belt in northern Finland. Contributions to Mineralogy and Petrology 104,369-379.

Janoušek, V., Farrow, C.M. \& Erban, V. 2006: Interpretation of wholerock geochemical data in igneous geochemistry: introducing Geochemical Data Toolkit (GCDkit). Journal of Petrology 47, 1255-1259.

Koistinen, T., Stephens, M.B., Bogatchev, V., Nordgulen, Ø., Wennerström, M. \& Korhonen, J. 2001: Geological map of the Fennoscandian shield, scale 1:2,000,000, Geological Surveys of Finland, Norway and Sweden and the North-West Department of Natural 
Resources of Russia.

Korja, A., Lahtinen, R. \& Nironen, M. 2006: The Svecofennian orogen: a collage of microcontinents and island arcs. In Gee, D.G. \& Stephenson, R.A. (eds.): European lithosphere dynamics, Geological Society of London Memoirs 32, pp. 561-578.

Krill, A.G., Bergh, S., Lindahl, I., Mearns, E.W., Often, M., Olerud, S., Sandstad, J.S., Siedlecka, A. \& Solli, A. 1985: Rb-Sr, U-Pb and Sm-Nd isotopic dates from Precambrian rocks of Finnmark. Norges geologiske undersøkelse Bulletin 403, 37-54.

Kullerud, K., Skjerlie, K.P., Corfu, F. \& de la Rosa, J.D. 2006: The 2.40 Ga Ringvassøy mafic dykes, West Troms Basement Complex, Norway: The concluding act of early Palaeoproterozoic continental breakup. Precambrian Research 150, 183-200.

Kyläkoski, M., Hanski, E. \& Huhma, H. 2012: The Petäjäskoski Formation, a new lithostratigraphic unit in the Paleoproterozoic Peräpohja Belt, northern Finland. Bulletin of the Geological Society of Finland 84, 85-120.

Lahtinen, R., Korja, A. \& Nironen, M. 2005: Paleoproterozoic tectonic evolution. In Lehtinen, M., Nurmi, P.A. \& Rämö, O.T. (eds.): Precambrian geology of Finland - Key to the evolution of the Fennoscandian Shield, Elsevier Science B.V., Amsterdam, pp. 481-532.

Lahtinen, R., Garde, A.A. \& Melezhik, V.A. 2008: Paleoproterozoic evolution of Fennoscandia and Greenland. Episodes 31, 20-28.

Lahtinen, R., Korja, A., Nironen, M. \& Heikkinen, P. 2009: Palaeoproterozoic accretionary processes in Fennoscandia. Geological Society of London Special Publications 318, 237-256.

Lahtinen, R., Huhma, H., Lahaye, Y., Jonsson, E., Manninen, T., Lauri, L.S., Bergman, S., Hellström, F., Niiranen, T. \& Nironen, M. 2015a: New geochronological and Sm-Nd constraints across the Pajala shear zone of northern Fennoscandia: Reactivation of a Paleoproterozoic suture. Precambrian Research 256, 102-119.

Lahtinen, R., Huhma, H., Lahaye, Y., Kousa, J. \& Luukas, J. 2015b: Archean-Proterozoic collision boundary in central Fennoscandia: revisited. Precambrian Research 261, 127-165.

Lauri, L.S. \& Lepistö, S. 2014: Finland, day 3, Wednesday the 27th of August 2014. In González, J. (ed.): Excursion guide, the $2^{\text {nd }}$ Arctic Mining Potential Excursion: Norrbotten-Käsivarsi-Tromsø-Narvik, 25-29 August 2014, Geological Survey of Sweden, pp. 44-60.

Lauri, L.S., Andersen, T., Holtta, P., Huhma, H. \& Graham, S. 2011: Evolution of the Archaean Karelian Province in the Fennoscandian Shield in the light of $\mathrm{U}-\mathrm{Pb}$ zircon ages and $\mathrm{Sm}-\mathrm{Nd}$ and $\mathrm{Lu}-\mathrm{Hf}$ isotope systematics. Journal of the Geological Society of London 168, 201-218.

Lauri, L.S., Andersen, T., Räsänen, J. \& Juopperi, H. 2012a: Temporal and $\mathrm{Hf}$ isotope geochemical evolution of southern Finnish Lapland from $2.77 \mathrm{Ga}$ to $1.76 \mathrm{Ga}$. Bulletin of the Geological Society of Finland 84, 121-140.

Lauri, L.S., Huhma, H. \& Lahaye, Y. 2012b: New age constraints for the Paleoproterozoic felsic volcanic rocks associated with the Koillismaa intrusion, Finland. In Mertanen, S., Pesonen, L.J. \& Sangchan, P. (eds.): Supercontinent Symposium 2012 - Programme and Abstracts, Geological Survey of Finland, Espoo, Finland, pp. 78-79.

Lauri, L.S., Hellström, F., Bergman, S., Huhma, H. \& Lepistö, S. 2016: New insights into the geological evolution of the Archean Norrbotten province, Fennoscandian shield, Bulletin of the Geological Society of Finland, Special Volume, Abstracts of the $32^{\text {nd }}$ Nordic Geological Winter Meeting, 13-15 January, Helsinki, Finland, p. 151.

Lehtonen, M., Airo, M.L., Eilu, P., Hanski, E., Kortelainen, V., Lanne, E., Manninen, T., Rastas, P., Räsänen, J. \& Virransalo, P. 1998: Kittilän vihreäkivialueen geologia. Lapin vulkaniittiprojektin raportti. Summary: The stratigraphy, petrology and geochemistry of the Kittilä greenstone area, northern Finland. A report of the Lapland Volcanite Project. Geological Survey of Finland, Report of Investigation, $144 \mathrm{pp}$.

Levchenkov, O.A., Levsky, L.K., Nordgulen, Ø., Dobrzhinetskaya, L.F., Vetrin, V.R., Cobbing, J., Nilsson, L.P. \& Sturt, B.A. 1993: U-Pb zircon age from Sørvaranger, Norway, and the western part of the
Kola Peninsula, Russia. In Roberts, D. \& Nordgulen, Ø. (eds.): Geology of the eastern Finnmark - western Kola Peninsula region, Norges geologiske undersøkelse Special Publication 7, pp. 29-47.

Lobach-Zhuchenko, S.B., Arestova, N.A., Chekulaev, V.P., Levsky, L.K., Bogomolov, E.S. \& Krylov, I.N. 1998: Geochemistry and petrology of 2.40-2.45 Ga magmatic rocks in the north-western Belomorian Belt, Fennoscandian Shield, Russia. Precambrian Research 92, 223250 .

Ludwig, K.R. 2001: Users manual for Isoplot/Ex version 2.49, a geochronological toolkit for Microsoft Excel. Berkeley Geochronology Center Special Pubication 1a, Berkley, 1-55.

Manninen, T. \& Huhma, H. 2001: A new U-Pb zircon constraint from the Salla schist belt, northern Finland. In Vaasjoki, M. (ed.): Radiometric age determinations from Finnish Lapland and their bearing on the timing of Precambrian volcano-sedimentary sequences, Geological Survey of Finland Special Paper 33, pp. 201-208.

Manninen, T., Pihlaja, P. \& Huhma, H. 2001: U-Pb geochronology of the Peurasuvanto area, northern Finland. In Vaasjoki, M. (ed.): Radiometric age determinations from Finnish Lapland and their bearing on the timing of Precambrian volcano-sedimentary sequences, Geological Survey of Finland Special Paper 33, pp. 189-200.

Martinsson, O., Billström, K., Broman, C., Weihed, P. \& Wanhainen, C. 2016: Metallogeny of the Northern Norrbotten Ore Province, northern Fennoscandian Shield with emphasis on IOCG and apatite-iron ore deposits. Ore Geology Reviews 78, 447-492.

Melezhik, V.A. \& Hanski, E.J. 2013: Palaeotectonic and palaeogeographic evolution of Fennoscandia in the Early Palaeoproterozoic (Chapter 3.3). In Melezhik, V.A., Prave, A.R., Fallick, A.E., Kump, L.R., Strauss, H., Lepland, A. \& Hanski, E.J. (eds.): Reading the archive of Earth's oxygenation; Volume 1: The Palaeoproterozoic of Fennoscandia as context for the Fennoscandian Arctic Russia Drilling Early Earth Project, Springer-Verlag, pp. 111-178.

Melezhik, V.A., Bingen, B., Sandstad, J.S., Pokrovsky, B.G., Solli, A. \& Fallick, A.E. 2015a: Sedimentary-volcanic successions of the AltaKvænangen Tectonic Window in the northern Norwegian Caledonides: Multiple constraints on deposition and correlation with complexes on the Fennoscandian Shield. Norwegian Journal of Geology 95, 245-284. http://dx.doi.org/10.17850/njg95-3-01.

Melezhik, V.A., Fallick, A.E., Brasier, A.T. \& Lepland, A. 2015b: Carbonate deposition in the Palaeoproterozoic Onega basin from Fennoscandia: a spotlight on the transition from the LomagundiJatuli to Shunga events. Earth-Science Reviews 147, 65-98.

Mertanen, S., Vuollo, J.I., Huhma, H., Arestova, N.A. \& Kovalenko, A. 2006: Early Paleoproterozoic-Archean dykes and gneisses in Russian Karelia of the Fennoscandian Shield-New paleomagnetic, isotope age and geochemical investigations. Precambrian Research 144, 239-260.

Mezger, K. \& Krogstad, E.J. 1997: Interpretation of discordant U-Pb zircon ages: an evaluation. Journal of Metamorphic Geology 15, $127-140$.

Mutanen, T. \& Huhma, H. 2003: The 3.5 Ga Siurua trondhjemite gneiss in the Archean Pudasjärvi Granulite Belt, northern Finland. Bulletin of the Geological Society of Finland 75, 55-68.

Myhre, P.I., Corfu, F., Bergh, S. \& Kullerud, K. 2013: U-Pb geochronology along an Archaean geotransect in the West Troms Basement Complex, North Norway. Norwegian Journal of Geology 93, 1-24.

Nasdala, L., Hanchar, J.M., Rhede, D., Kennedy, A.K. \& Váczi, T. 2010: Retention of uranium in complexly altered zircon: An example from Bancroft, Ontario. Chemical Geology 269, 290-300.

Nasuti, A., Roberts, D. \& Gernigon, L. 2015a: Multiphase mafic dykes in the Caledonides of northern Finnmark revealed by a new highresolution aeromagnetic dataset. Norwegian Journal of Geology 95, 285-297. http://dx.doi.org/10.17850/njg95-3-02.

Nasuti, A., Roberts, D., Dumais, M.-A., Ofstad, F., Hyvönen, E., Stampolidis, A. \& Radionov, A. 2015b: New high-resolution aeromagnetic and radiometric surveys in Finnmark and North Troms: linking anomaly patterns to bedrock geology and structure. 
Norwegian Journal of Geology 95, 217-243. http://dx.doi. org/10.17850/njg95-3-10.

Nilsen, K.S. \& Bjørlykke, A. 1991: Geological setting of the Bidjovagge gold-copper deposit, Finnmark, northern Norway. Geologiska Föreningen i Stockholm Förhandlingar 113, 60-61.

Nilsson, L.P. \& Juve, G. 1979: En kjemisk-mineralogisk undersøkelse av ultramafiske bergarter i Komagfjordvinduet med henblikk på å bestemme eventuelle økonomiske konsentrasjoner av malmmineraler. Norges geologiske undersøkelse Report 1682/1,75 pp.

Nironen, M. 2005: Proterozoic orogenic granitoid rocks. In Lehtinen, M., Nurmi, P.A. \& Rämö, O.T. (eds.): Precambrian Geology of Finland. Key to the Evolution of the Fennoscandian Shield, Elsevier Science B.V., Amsterdam, pp. 443-480.

O'Connor, J.T. 1965: A classification for quartz-rich igneous rocks based on feldspar ratios. US Geological Survey Professional Paper B525, 79-84.

Often, M. 1985: The Early Proterozoic Karasjok Greenstone Belt, Norway: a preliminary description of lithology, stratigraphy and mineralization. Norges geologiske undersøkelse Bulletin 403,75-88.

Olsen, K.I. \& Nilsen, K.S. 1985: Geology of the southern part of the Kautokeino Greenstone Belt: Rb-Sr geochronology and geochemistry of associated gneisses and late intrusions. Norges geologiske undersøkelse Bulletin 403, 131-160.

Olesen, O. \& Solli, A. 1985: Geophysical and geological interpretation of regional structures within the Precambrian Kautokeino Greenstone Belt, Finnmark, North Norway. Norges geologiske undersøkelse Bulletin 403, 119-129.

Olesen, O. \& Sandstad, J.S. 1993: Interpretation of the Proterozoic Kautokeino Greenstone Belt, Finnmark, Norway, from combined geophysical and geological data. Norges geologiske undersøkelse Bulletin 425, 41-62.

Olesen, O., Roberts, D., Henkel, H., Lile, O.B. \& Torsvik, T.H. 1990: Aeromagnetic and gravimetric interpretation of regional structural features in the Caledonides of West Finnmark and North Troms, Northern Norway. Norges geologiske undersøkelse Bulletin 419, $1-24$.

Pascal, C., Balling, N., Barrère, C., Davidsen, B., Ebbing, J., Elvebakk, H., Mesli, M., Roberts, D., Slagstad, T. \& Willemoes-Wissing, B. 2010: HeatBar Final Report 2010, Basement Heat Generation and Heat Flow in the western Barents Sea - Importance for hydrocarbon systems. Norges geologiske undersøkelse Report 2010.030,91 pp.

Peltonen, P. 2005: Ophiolites. In Lehtinen, M., Nurmi, P.A. \& Rämö, O.T. (eds.): Precambrian Geology of Finland. Key to the Evolution of the Fennoscandian Shield, Elsevier Science B.V., Amsterdam, pp. 237-278.

Peltonen, P., Kontinen, A. \& Huhma, H. 1996: Petrology and geochemistry of metabasalts from the $1.95 \mathrm{Ga}$ Jormua ophiolite, northeastern Finland. Journal of Petrology 37, 1359-1383.

Peltonen, P., Kontinen, A. \& Huhma, H. 1998: Petrogenesis of the mantle sequence of the Jormua ophiolite (Finland): melt migration in the upper mantle during Palaeoproterozoic continental breakup. Journal of Petrology 39, 297-329.

Perelló, J., Clifford, J.A., Creaser, R.A. \& Valencia, V.A. 2015: An example of synorogenic sediment-hosted copper mineralization: geologic and geochronologic evidence from the Paleoproterozoic Nussir deposit, Finnmark, Arctic Norway. Economic Geology 110, 677-689.

Perttunen, V. \& Vaasjoki, M. 2001: U-Pb geochronology of the Peräpohja Schist Belt, northwestern Finland. In Vaasjoki, M. (ed.): Radiometric age determinations from Finnish Lapland and their bearing on the timing of Precambrian volcano-sedimentary sequences, Geological Survey of Finland Special Paper 33, pp. 45-84.

Pharaoh, T.C. \& Brewer, T.S. 1990: Spatial and temporal diversity of early Proterozoic volcanic sequences - comparisons between the Baltic and Laurentian shields. Precambrian Research 47, 169-189.

Pharaoh, T.C., Macintyre, R.M. \& Ramsay, D.M. 1982: K-Ar age determination on the Raipas suite in the Komagfjord Window, northern
Norway. Norsk Geologisk Tidsskrift 62, 51-57.

Pharaoh, T.C., Ramsay, D.M. \& Jansen, Ø. 1983: Stratigraphy and structure of the Repparfjord-Komagfjord Window, Finnmark, Northern Norway. Norges geologiske undersøkelse Bulletin 377, 1-45.

Pharaoh, T.C., Warren, A. \& Walsh, N.J. 1987: Early Proterozoic volcanic suites of the northernmost of the Baltic Shield. In Pharaoh, T.C., Beckinsale, R.D. \& Rickard, D. (eds.): Geochemistry and mineralization of Proterozoic volcanic suites, Geological Society of London Special Publications 33, pp. 41-58.

Poudjom Djomani, Y.H., O’Reilly, S.Y., Griffin, W.L. \& Morgan, P. 2001: The density structure of subcontinental lithosphere through time. Earth and Planetary Science Letters 184, 605-621.

Puchtel, I.S., Hofmann, A.W., Mezger, K., Shchipansky, A.A., Kulikov, V.S. \& Kulikova, V.V. 1996: Petrology of a 2.41 Ga remarkably fresh komatiitic basalt lava lake in Lion Hills, central Vetreny Belt, Baltic Shield. Contributions to Mineralogy and Petrology 124, 273-290.

Puchtel, I.S., Haase, K.M., Hofmann, A.W., Chauvel, C., Kulikov, V.S., Garbe-Schönberg, C.D. \& Nemchin, A.A. 1997: Petrology and geochemistry of crustally contaminated komatiitic basalts from the Vetreny Belt, southeastern Baltic Shield: Evidence for an early Proterozoic mantle plume beneath rifted Archean continental lithosphere. Geochimica et Cosmochimica Acta 61, 1205-1222.

Puchtel, I.S., Arndt, N.T., Hofmann, A.W., Haase, K.M., Kröner, A., Kulikov, V.S., Kulikova, V.V., Garbe-Schönberg, C.D. \& Nemchin, A.A. 1998: Petrology of mafic lavas within the Onega plateau, central Karelia: evidence for $2.0 \mathrm{Ga}$ plume-related continental crustal growth in the Baltic Shield. Contributions to Mineralogy and Petro$\log y 130,134-153$.

Ranta, J.P., Lauri, L.S., Hanski, E., Huhma, H., Lahaye, Y. \& Vanhanen, E. 2015: U-Pb and Sm-Nd isotopic constraints on the evolution of the Paleoproterozoic Peräpohja Belt, northern Finland. Precambrian Research 266, 246-259.

Räsänen, J. \& Huhma, H. 2001: U-Pb datings in the Sodankylä schist area of the Central Lapland Greenstone Belt. In Vaasjoki, M. (ed.): Radiometric age determinations from Finnish Lapland and their bearing on the timing of Precambrian volcano-sedimentary sequences, Geological Survey of Finland Special Paper 33, pp. 153-188.

Rastas, P., Huhma, H., Hanski, E., Lehtonen, M.I., Härkönen, I., Kortelainen, V., Mänttäri, I. \& Paakkola, J. 2001: U-Pb isotopic studies on the Kittilä greenstone area, central Lapland, Finland. In Vaasjoki, M. (ed.): Radiometric age determinations from Finnish Lapland and their bearing on the timing of Precambrian volcano-sedimentary sequences, Geological Survey of Finland Special Paper 33, pp. 95-142.

Reitan, P.H. 1963: The geology of the Komagfjord tectonic window of the Raipas suite, Finnmark, Norway. Norges geologiske undersøkelse Bulletin 221,71 pp.

Roberts, D. 2003: The Scandinavian Caledonides: event chronology, palaeogeographic settings and likely modern analogues. Tectonophysics 365, 283-299.

Sandstad, J.S. 1984: Berggrunnsgeologisk kartlegging av prekambrisk grunnfjell innen kartbladet Mållejus, Kvænangen/Kautokeino, Troms/Finnmark. Norges geologiske undersøkelse Report 1886/5, 31 pp.

Sandstad, J.S. 1985: Geologisk berggrunnskart Mallejus, scale 1:50,000, Norges geologiske undersøkelse.

Sandstad, J.S., Bjerkgård, T., Boyd, R., Ihlen, P.M., Korneliussen, A., Nilsson, L.P., Often, M., Eilu, P. \& Hallberg, A. 2012: Metallogenic areas in Norway. In Eilu, P. (ed.): Mineral deposits and metallogeny of Fennoscandia, Geological Survey of Finland Special Paper 53, pp. $35-138$.

Seydoux-Guillaume, A.M., Bingen, B., Paquette, J.L. \& Bosse, V. 2015: Nanoscale evidence for uranium mobility in zircon and the discordance of $\mathrm{U}-\mathrm{Pb}$ chronometers. Earth and Planetary Science Letters 409, 43-48.

Siedlecka, A., Iversen, E., Krill, A.G., Lieungh, B., Often, M., Sandstad, J.S. \& Solli, A. 1985: Lithostratigraphy and correlation of the 
Archean and Early Proterozoic rocks in Finnmarksvidda and the Sørvaranger district. Norges geologiske undersøkelse Bulletin 403, 7-36.

Sigmond, E.M.O., Gustavson, M. \& Roberts, D. 1984: Berggrunnskart over Norge, scale 1:1,000,000, Norges geologiske undersøkelse.

Skiöld, T. 1986: On the age of the Kiruna Greenstones, Northern Sweden. Precambrian Research 32, 35-44.

Skiöld, T. \& Cliff, R.A. 1984: Sm-Nd and U-Pb dating of Early Proterozoic mafic-felsic volcanism in Northernmost Sweden. Precambrian Research 26, 1-13.

Slabunov, A.I., Lobach-Zhuchenko, S.B., Bibikova, E.V., SorjonenWard, P., Balagansky, V.V., Volodichev, O.I., Shchipansky, A.A., Svetov, S.A., Chekulaev, V.P., Arestova, N.A. \& Stepanov, V.S. 2006: The Archaean nucleus of the Fennoscandian (Baltic) Shield. In Gee, D.G. \& Stephensoy, R.A. (eds.): European Lithosphere Dynamics, Geological Society of London Memoirs 32, pp. 627-644.

Solli, A. 1983: Precambrian stratigraphy in the Masi area, southwestern Finnmark, Norway. Norges geologiske undersøkelse Bulletin 380, 97-105.

Stepanova, A.V., Samsonov, A.V., Salnikova, E.B., Puchtel, I.S., Larionova, Y.O., Larionov, A.N., Stepanov, V.S., Shapovalov, Y.B. \& Egorova, S.V. 2014: Palaeoproterozoic continental MORB-type tholeiites in the Karelian Craton: Petrology, geochronology, and tectonic setting. Journal of Petrology 55, 1719-1751.

Stepanova, A.V., Salnikova, E.B., Samsonov, A.V., Egorova, S.V., Larionova, Y.O. \& Stepanov, V.S. 2015: The $2.31 \mathrm{Ga}$ mafic dykes in the Karelian Craton, eastern Fennoscandian shield: U-Pb age, source characteristics and implications for continental break-up processes. Precambrian Research 259, 43-57.

Torgersen, E. \& Viola, G. 2014: Structural and temporal evolution of a reactivated brittle-ductile fault - Part I: Fault architecture, strain localization mechanisms and deformation history. Earth and Planetary Science Letters 407, 205-220.

Torgersen, E., Viola, G., Zwingmann, H. \& Harris, C. 2014: Structural and temporal evolution of a reactivated brittle-ductile fault - Part II: Timing of fault initiation and reactivation by K-Ar dating of synkinematic illite/muscovite. Earth and Planetary Science Letters 407, 221-233.

Torgersen, E., Viola, G. \& Sandstad, J.S. 2015a: Revised structure and stratigraphy of the northwestern Repparfjord Tectonic Window, northern Norway. Norwegian Journal of Geology 95, 397-421. http://dx.doi.org/10.17850/njg95-3-06.

Torgersen, E., Viola, G., Sandstad, J.S., Stein, H., Zwingmann, H. \& Hannah, J. 2015b: Effects of frictional-viscous oscillations and fluid flow events on the structural evolution and Re-Os pyritechalcopyrite systematics of $\mathrm{Cu}$-rich carbonate veins in northern Norway. Tectonophysics 659, 70-90.

Torske, T. \& Bergh, S.G. 2004: The Caravarri Formation of the Kautokeino Greenstone Belt, Finnmark, North Norway; a Palaeoproterozoic foreland basin succession. Norges geologiske undersøkelse Bulletin 442, 5-22.

Väänänen, J. \& Lehtonen, M.I. 2001: U-Pb isotopic age determinations from the Kolari-Muonio area, Western Finnish Lapland. In Vaasjoki, M. (ed.): Radiometric age determinations from Finnish Lapland and their bearing on the timing of Precambrian volcanosedimentary sequences, Geological Survey of Finland Special Paper 33, pp. 85-93.

Villa, I.M. 2016: Diffusion in mineral geochronometers: present and absent. Chemical Geology 420, 1-10.

Whitehouse, M.J. \& Kamber, B.S. 2005: Assigning dates to thin gneissic veins in high-grade metamorphic terranes: a cautionary tale from Akilia, Southwest Greenland. Journal of Petrology 46, 291-318.

Whitehouse, M.J., Kamber, B.S. \& Moorbath, S. 1999: Age significance of U-Th-Pb zircon data from early Archaean rocks of west Greenland - a reassessment based on combined ion-microprobe and imaging studies. Chemical Geology 160, 201-224.

Åm, K. 1975: Aeromagnetic basement complex mapping north of lati- tude $62^{\circ} \mathrm{N}$, Norway. Norges geologiske undersøkelse Bulletin 316, 351-374. 